\title{
THE SURFACE CHEMISTRY OF FLOTATION
}

\section{by}

Robert Lougheed Bennett

A Thesis submitted for the Degree of MASTER OF APPLIED SCIENCE

In the Dopartment

$$
\text { of }
$$

CHEMISTRY

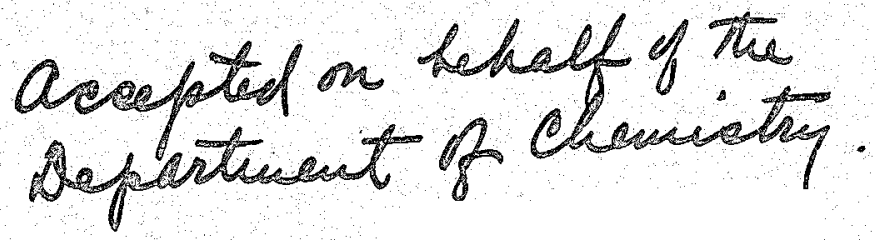

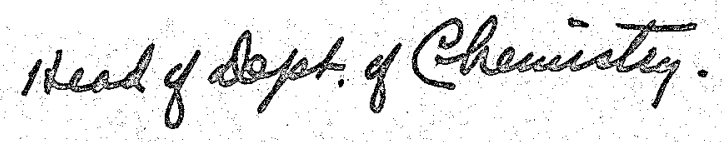

The University of British Columbia 
THE SURFACE CHEMISTRY OF FLOTATION

PART 1.

BIBLIOGRAPHY 


\section{THE SURFACE CHEMISTRY OF FLOTATION}

* PART 1. BIBLIOGRAPHY

\section{CONTENTS}

Chapter 1.

HISTORICAI AND INTRODUCTORY

Chapter 2.

AN ANNOTATED BIBLIOGRAPHY OF

BXPERIMENTAL AND THEORETICAL INVESTIGATIONS IN

THE PHYSICAI CHEMISTRY OF FLOTATION

I. INTRODUCTORY

II. FROIH FORMATION

III. COLIECTION

1. Collectors

Definition of a collector

Examples of Collectors

structure of Collectors

Preparation and Purification of Collectors and their Compounds

Chemical Reactions of Collectors

Physlcal Properties of collectors and their Compounds

2. Hifrect of Varlous keagents on Recovery in Flotation fiests and Practice

Small Scale Flotation Tests

Floatablity of Pure Minerals (Inherent Floatability) 
Ef fect of Varlous Reagents on the Recovery of Minerals in the Presence of a Collector. CGalena - Pyrite - Sphalerite - Chalcocite - Chal copyrite - Miscellaneous Sulfide Minerals - Oxidized Minerals - Nonmetallic inerals)

Specifle Effects of Collectors on Minerals

Influence of remperature on Floatability

3. Experimental Evidence for the Reaction of Collectors with Minerals

Changes in a Collector solution in Contact with a Mineral (Abstraction: In general - by galena - pyrite - sphalerite - chalcocite chalcopyrite - sulfur and graphite - miscelIaneous minerals)

Changes in a Mineral in Contact with a collector Solution.

(Physical nature of coating - Analysis of coatings on galena - pyrite - chalcocite miscellaneous minerals)

4. Contact Angles as a Measure of Floatabl11ty

The Contact Angle

Significance of the contact Angle as a Measure of Floatablity

effect of various factors on the contact Angle

Hysteresis of Contret Angle

Iime to Develop contact

inscellaneous contact Angle Investigations 41

5. Electrical effects in Flotation

Charge on Minerals, AIr Bubbles, and 011 Partieles

Potential of Mineral Electrodes

Effect of Reagents on Mineral Charge $\quad 43$

6. Thermodynamies of Flotation 
Surface Emergy

Page

Displacement Pressure and Adhesion Tension

Contact Angle as a Therrodynamic Quantlty

7. Miscellaneous studies of Wetting

8. Theories of Collector Action

Introductory

Chemlcal theory

Adsorption theory

Ostwald's theory

Electrical theories

M1scellaneous theories

1. Evidence of Depression obtained from Flotation Tests and practice chal cocite - chal copyrite - miscellaneous minerals)

2. Experimental uvidence for the Reaction of Depressors with Minerals

Changes in a solution of Depressor in Contact With a Mineral (Abstraction of Depressor by galena - pyrite - chalcopyrite - sphalerite)

Changes in a Mineral in Contact with a Depressor Solution

3. Contact Angle studies of Depression

Depression by Cyanide

Galena - pyrite - sphalerite - chalco-

pyrite - miscellaneous minerals)

Depression by sodium sulfide

Depresston by other reagents

Depression in General 


\section{Page}

4. Theorles of Depressor Action

71

Depression by Cyanide

71

Depression by Reagents other than Cyanide

(Chromates - Iime - Sulfites - Miscellaneous Reagents)

V. ACTIVATTON

1. Hvidence of Activation Obtalned from Flotation Tests and Practice

(Pyrite - sphalerite - miscellaneous sulfide minerals - oxidized minerals - non-metallic minerals)

2. Hxperimental Evidence for the keaction of ActiFators with Minerals

Changes in a solution of Activator in Contact. with a Mineral (Abstraction of Activator)

Changes in a Mineral in Contact with an Act1vator solution

3. Contact Angle Studies of Activation

4. Theories of Activator Action 
THE SURFACE CHEMISTRY OF FLOTATION

\section{$\therefore \quad$ CHAPTER I \\ HISTORICAL AND INTRODUCTORY}

Flotation is a process of ore concentration in which the ore minerals are separated into two or more products. one product, usually containing worthless minerals, is termed tailings; the other products, containing the valuable minerals in a more concentrated state, are termed concentrates.

In modern flotation, air is generated in, or introduced into a pulp of finely-ground ore suspended in water, which contains small amounts of various reagents. Because of the presence of froth-forming reagents, a zone of rising froth forms at the upper surface of the pulp, and flows over the Ilp of the containing vessel. Ihe minerals in the ore-pulp. are mechanically carried into this froth zone to a greater or less extent. Certain minerals show a greater tendency than others to be carried into the froth by the air bubbles rising through the pulp; and, once in the froth, to rise with 1t. These minerals eventually reach the upper surface of the froth, overflow with 1 , and are removed as concentrate. other minerals either do not enter the froth; or, if they do enter, tend to settle out and fall back into the pulp. To do this, their effective downward velocity in the froth must be greater than the effective upward velocity with which the froth is rising. these minerals eventually remain 
suspended In the pulp and are removed as tailings. Ihe density of a given mineral does not determine whether the mineral will become concentrate or tailing.

Early flotation processes, whlch have become obsolete, are bulk-oil flotation, and skin-flotation.

The first practical process of flotation was the bulko11 process, introduced by w111iam Haynes in 1860 (Brit. Pat. $488 / 1860$ ) and modified by Carrie J. Everson (U.S.Pat. 348,157 -1885). The EImore process, typlcal of bulk-oil flotation, consisted in treating ore with water and large quantities of oil; selective adsorption of certain minerals in the olI phase, or at the 0il-water interface; and removal of the mineral-containing oil after it had risen to the surface of the water.

Skin-flotation consisted of retention of selected mineral particles in a thin layer at a free water surface. Apparatus for this process is described by llacquisten (U.S.Pat. 865,194-5/1907) and Wood (U.S.Pat. 1,088,050/1915) $(28.6 .1)$

Gas as a buoyant medium was introduced by Delprat in 1902 (U.S.Pat 735,071/1903; Brit.Pat.26,279/1902) and by potter in 1904 (U.S.Pat. 776,145/1904). The Botter-Delprat Process involved chemical generation of gas by the reaction of acid with sulfides and carbonates contained in the ore. This process marks the beginning of froth flotation as now practiced.

Air was first introduced directly into the pulp by 
sulman, Picard and ballot in 1906 (U.S.Pat. $835,120 / 1906$ ). With. the use of alr instead of 011 as a buoyant medium, it was found that the quantity of oll could be materially reduced without affecting performance.

In 1909 Greenway, SuIman and HIggins (U.S.Pat. 962,678) $1909)$ recommended the use of soluble frothing agents, such as pine oil. The quantities of such agents which were required, were of the order of less than one pound per ton of ore. Whis patent marks the recognition of frothing agents; although the frothers used also had collecting power, as defined below.

During the period from 1915 to 1922 , certain non-frothing reagents, having the property of collecting desired minerals Into the froth, were introduced.

In 1921, Perkins (U.S.Pat 1,364,304/1921) differentiated between the frothing and the collecting functions of a reagent. He showed that certain non-oleaginous organic compounds, containing trivalent nitrogen or divalent sulfur, specifically thiocarbanilla, or other thloamido, or thiourea compounds, had the property of increasing the tendency of a mineral to adhere to the air phase, and be collected in the froth. Compounds which have this property are now termed collectors. The action by which the alr-adhering tendency Is increased, is termed collection. The compounds intooduced by perkins had no frothing properties, and were designed to be used in conjunction with known reagents which would cause a froth to form. 
Xanthates as collectors were patented in 1925 by $R e I l e r$ (U.S.Pat. 1,554,216/1925; Can.Pat.247,547/1925), and dithiophosphates of the type formula:

$$
S=\frac{P-O R}{S H} \quad R=\text { hydrocarbon group }
$$

prepared from phosphorus pentesulfide and cresylic acid, were patented in 1926 by whitworth (U.S.Pat. 1,593,232/1926) The patent of perkins in 1921 marks the beginning of a new flotation technique, which has been termed "chemical plotation", in contrast to the older "oll flotation".

This brief survey has indicated the stages in the development of frothing and collection, as practiced in . modern flotation. Mention must be made, also, of the development of two other phases of flotation. these are activation and depression.

Activation of a specific mineral, or minerals, is accomplished by adding to the ore-pulp a reagent, termed an activator, whlch will cause the mineral, otherwise unaffected by a collector, to be collected into the froth. Depression is accomplithd by adding a reagent, temed a depressor, which will cause the mineral, nomally collected, to oe depressed; that is, unaffected by the collector. Schwarz in 1906 (U.S.Pat $807,501 / 1906$ ) introduced alkali sulfides or polysulfides as activators for oxidized ores.

Copper sulfate, the most common activator for sphalerite, was discovered by Bradford in 1913. 
Dichromates, as depressors for galena, were suggested by Lowry and Greenway in 1912 (Austral. Pat. 5,065/1912)

oil flotation was usually carried out in an acid circuit, but with the advent of chemical flotation about 1921, alkaline circuits soon became common practice. the use of alkaline circuits led to the discovery of the depressing effect of lime on pyrite, and of cyanide on sphalerite by sheridan and Griswold (U.S.Pats. 1,421,585/1922; 1,427,235/ 1922) 
CHAPTER II

AN ANNOTATED BIBLIOGRAPHY OF

EXPERIMENTAI AND THEOREITCAI INVESTIGATIONS IN

THE PHYSICAL GHEMISTRY OF FLOTATION

INTRODUCTORY

Flotation has developed largely as an art. Discoveries, in many cases, have been the result of trial and error. Until about 1928, very little fundamental experimental work was done, although several theories were advenced. Much of the experimental work carried on since has dealt with the extremely complex systems existing in a flotation cell treating natural ores. While such work has given definite information regaraing treatment methods for a specific ore, it has throw little light on the fundamental reactions taking place. Harly experimenters often failed to realize the delicate nature of the reactions they dealt with, and the profound effect on flotation performance of almost intangible amounts of reagents. The fact that as small a quantity as $0.002 \mathrm{mgm}$. of potassium cyanide is sufficient to prevent a $6 \mathrm{sq}$. ch. area of pyrite from being floated; and a comparable amount of copper sulfate will cause sphalerite, otherwise unfloatable, to be floated; emphasize the necessity for extreme care in investigating the phenomena of flotation. 
These facts must be carried in mind when considering the following experimental work, and the conclusions based upon it. Whis mork is considered as it relates to the study of four fundamental chemical operations: froth formation, collection, depression, and activation. 
FROTH FORMATION

A froth is a dispersion of a gas In a liquid, which forms when the gas-bubble walls are made capable of withstanding stresses. They are in this condition when the surface-tension of the liquid-gas interface, forming the bubble wall is capable of rapid change. If a caplliary active substance is dissolved in water it will tend to concentrate in the froth $(03.8 .1)$ at the alr-water Interfaco, In agreement with the Gibb's equation relating the amount of adsorption of a substance at an interface to its effect on surface tension. If a film of such a solution is stretched, the concentration of the substance in the surface is decreased, and the surface tension of the film necessarily increases; thas setting up a force which will oppose the stretching force.

Frothing agents, as used in flotation, are capillary active substances which stabilize a froth in this way.

Langmuir's work $(16.25 .2)(17.25 .2)$ suggests that oriented adsorption of a monomolecular film of a heteropolar frother such as amyl alcohol, will occur at the airwater interface, in such a way that the non-polar hydrocarbon group is oriented towards the gas phase.

laggart and Gaudin $(22.3 .1)$ note the heteropolar character of molecules of the frothers used in flotation. Bartsch (24.25.I)(24.25.2) finds that hydrocarbons, chloroform, carbon tetrachloride and carbon disulfide have little 
or no frothing, or foam stabilizing ability; but organic acids, alcohols, amines, aldehydes, ketones, etc. ald in the production End stability of foams. Each reagent has an optimum concentration for greatest foam stability. He notes that minerals also exert a stabilizing effect.

As a result of a statistical study of a largo number of organic compounds, in whlch both the frothing effect, measured by a special apparatus, and flotation performance, are correlated to structure, Taggart, laylor and Ince $(30.3 .3)$ state that the molecule of a non-collecting frother should contain one (and preferably one only) oxygen-bearing, wateravid group, such as:

$-\mathrm{OH} \quad-\mathrm{C}^{\circ \mathrm{O}} \mathrm{OH} \quad=\mathrm{O}=\mathrm{O}$

at least a six carbon-atom chain, attached to the above group; and that the compound should have a solubility in water of about $1 \mathrm{gm}$. per $11 \mathrm{tr} \theta$.

Because the solubility of the compounds studied decreases with 'hydrocarbon Ioading', they suggest the hydrocarbon group is hydrophobic, while the rest of the molecule is hydrophilic, in Ine with Langmuir's treatment of partial solubility.

Frothing of solutions of an homologous series increases to a certain point, then decreases with increasing molecular weight; presumably because of the decreasing solubility of the higher members.

Gaudin $(32.25 .5)$ states that the presence in a frother of lonizable polar groups such as $-\mathrm{COOH}$ or $-\mathrm{NH}_{2}$ wiII 
cause it to have collecting tendencies.

- The modern conceptions of frothing have been summarIzed by del Giuelce $(34.6 .3)$

A device for testing the frothing properties of flotation reagents is described by Christmann (U.S.Pat. 1,866,296) 1932).

In practice, pine oil or cresylic acla are almost exclusively used as frothing agents. Little attention was paid to the development of new frothers until the work of Dean and Hersberger $(35.3 .1)$. They state that the ideal frother, in low concentrations, Should form a coplous but not too persistent froth; the froth should be independent of pH, added salts, and added collectors; and the frother should be non-collecting, but should emulsify and disperse insoluble collecting agents. By balancing polar and nonpolar groups, and making use of the fact that a complex polar group will allow long chain hydrocarbon groups to be used without decreasing the solubility of the compound too greatly, they propose a list of compounds which should conform to the specified characteristics.

recent frother patents are reviewed by Bassett (38.4.1) 


\section{COLLECTION}

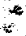

Definition of a collector

Collectors are reagents, invartably organic, which react with a mineral in such a way that its tendency to adhere to air, in preference to water; hence its tendency to float, is increased.

\section{Examples of Collectors}

Exemples of such reagents, commonly used, are:

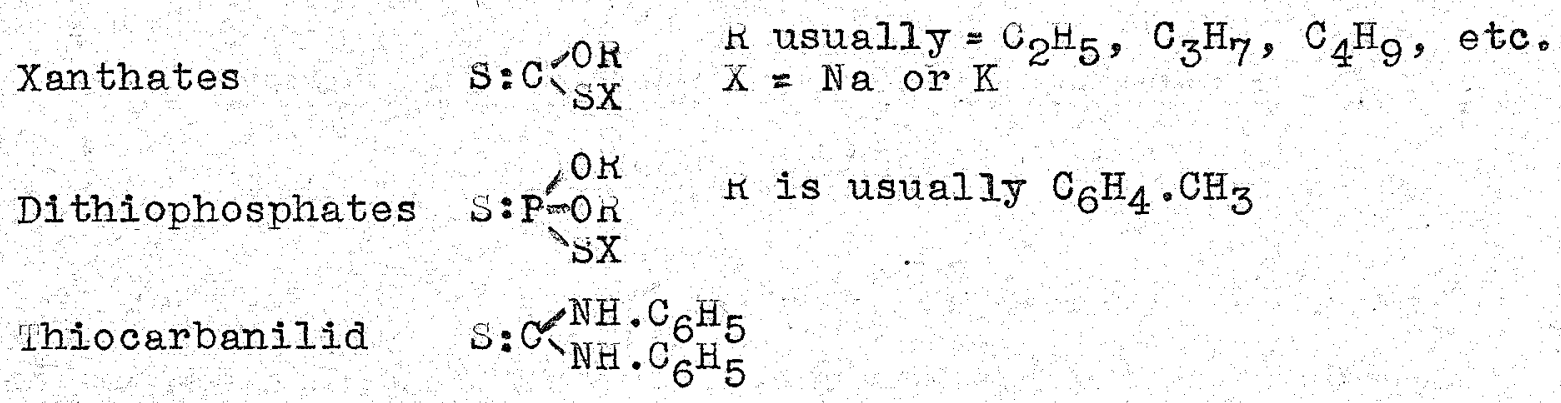

Diazoaminobenzene $\mathrm{C}_{6} \mathrm{H}_{5} \mathrm{~N}: \mathrm{N} \cdot \mathrm{NH} \cdot \mathrm{C}_{6} \mathrm{H}_{5}$

Irimethylcetyl ammonium bromide $\begin{aligned} & \mathrm{CH}_{3} \\ & \mathrm{CH}_{3}\end{aligned} \mathrm{C}_{B}{ }_{1}^{\mathrm{C}} 6^{\mathrm{H}_{33}}$

\section{structure of Collectors}

The heteropolar nature of collector molecules was early recognized $(24.3 .1)(28.3 .1)$. Laggart, laylor and Ince (30.3.3), from a statistical study of the collecting Index (an arbitrary measure of collecting effect, dependent on contact angle measurements) for a large number of organic compounds, reach the conclusion that the effectiveness of 
a compound as a collector depends on the hydrocarbon group present in the molecule. From studies of the abstraction of a collector from solution by a mineral, they show that abstraction is dependent on the presence of a : S or similar group. They state that non-frothing collector molecules must contain divalent sulfur, trivalent nitrogen, or other multivalent negative element in the low valent state, and must have a hydrocarbon complex with 8 or more carbon atoms. the compound should have a solubility of 200 to $300 \mathrm{mgm}$. per litre in water, and probably possess the ability to form relatively insoluble base metal salts.

\section{Preparation and Purification of Gollectors and their Compounds.}

The methods of Foster (28.19.2) for the preparation of xanthates and other trithiocarbonates have been quoted by taudin $(32.25 .5)$. Foster's method has been modified by De Witt and koper (32.1.1) in their preparation of a highly purified potassium ethyl xanthate.

Gaudin and schumann $(36.8 .3)$ give methods for the preparation and purification of potassium n-amyl xanthate and cuprous $n$-amyl xanthate.

\section{Ghemical Reactions of Collectors}

A study of the solubility and kinetics of decomposition of xanthic acids in water shows that decomposition is accelerated by hydrogen lons, and retarded by sulfate ions (18.25.I) 
The kinetics of decomposition in organic liquids has also been studied $(13.25 .1)$. The decomposition is accelerated in liquidse containing $.0 \mathrm{H}$ groups.

Alkali xanthates decompose in acid solution to form carbon disulfide and alcohol. If, however, the pH is not below 5 , and the temperature is less than $5^{\circ} \mathrm{C}$. (13.25.1), the stable, water-insoluble xanthic acid is formed.

In 1 to 2 normal alkaline solution, xanthate ion is decomposed $(08.25 .1)$, as evidenced by the composition of the insoluble cuprous salts precipitated from such a solution. It is probable that mono-, di-, or trithiocarbonates are formed. Iaylor and Knoll $(34.3 .7)$ consider the most probable decomposition products of an aqueous solution of an alkali xanthate are either dixanthogen ${ }^{2}$, or carbon disulflde and alcohol.

De Witt and Roper (32.1.1) state that the hydroxyl ion derived from hydrolysis cannot account for the observed $\mathrm{pH}$ change in solutions of potassium ethyl xanthate. Schaum, siedler and Wagner (32.12.3) note very slight hydrolys is of 0.01 normal xanthate solutions at room temperature. The hydrolysis increases autocatalytically after 20 hours. They consider xanthates, at the concentrations used in flotation, are completely dissociated.

Taylor and Knoll investigated the stability of potassium ethyl xanthate solutions $(34.3 .7)$, and find that a

1. Dixanthogen $=\left(\mathrm{S}: \mathrm{C}_{\mathrm{S}} \mathrm{OR}\right)$ 
water solution has a $\mathrm{pH}$ of 7.2 . Conductivity measurements indicate ethyl xanthic acid is a strong acid.

Sodium or potassium ethyl xanthate, from a solution containing cupric lons, precipitates yellow cuprous ranthate ${ }^{2}$ $(1835.25 .1)(08.25 .2)(10.25 .1)(31.1 .1)$, and from a solution containing lead ions, precipitates white lead xanthate (34.3.7) as determined by analyzing the precipitates for base metals. Taggart, del Giudice and Ziehl $(34.3 .6)$ state that ferrous salts, with xanthate ion, on oxidation, form a precipitate which is probably dixanthogen and ferric xanthate; that ferric salts, with ethyl xanthate ion, form ferric ethyl xanthate, as determined by analysis. They give a table of the reactions of collectors with heavy metal ions.

\section{Physical Properties of Collectors and their Compounds}

The solubility in water at $0^{\circ} \mathrm{C}$. of sodium methyl and ethyl xanthates is reported to be 0.05 and 0.02 mol. per Iitre, respectively $(18.25 .1)$

The surface tension of aqueous solutions of potassium ethyl xanthate has been measured by De Witt and associates (32.1.1)(35.1.1) who note that solutions of the isomeric forms of potassium ethyl xanthate have different surface tensions.

laggart and co-workers mention the solubility of zinc ethyl xanthate is about $335 \mathrm{mgm}$. per litre $(30.3 .1)$; that of

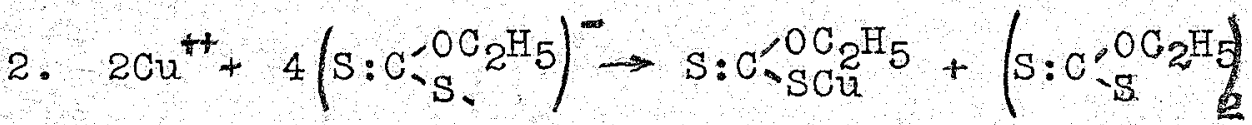


Iead ethyl xanthate is $0.2 \mathrm{mgm}$. per litre $(32.8 .1)$.

- Weinig and Palmer $(29.25 .4)$ state that xanthates are more soluble than the corresponding sulfides.

Brighton, Burgener and Gross (32.6.2) find that the solubility of oupric and zinc n-amyl, and cupric ethyl xanthates is increased by increase in sodium cyanide concentration. they report the solubility in water of zinc n-amyl xanthate as $80 \mathrm{mgm}$. per litre; lead n-amyl xanthate as 30 mgm. per litre. they were unable, using colorimetric methods, to determine copper xanthates in water, or lead. xanthate in sodium cyanide solution.

the relative solubilities of various metallic xanthates in water have been determined by Warren $(33.5 .1)$. Gaudin (34.3.5A) gives solubilities for cuprous n-amyl xanthate in various organic solvents, as follows: acetone 16, diethyl ether 15, carbon disulfide 7.3 , benzene 388 , petroleum ether less than 1 mgm. per litre. 
BEFECT OF VARIOUS REAGENTS ON KHCOVEKY IN FIOTATION TESTS AND PRACITCE

Small scale Flotation lests

The small scale flotation test is probably the oldest experimental technique used in studying flotation phenomena. Various devices have been described for this work; many manufacturers market miniature cells, taking a charge of 500 or 1000 grams, which are miniatures of thelr plant units. A 50 gram agitation type cell, with automatic froth overflow Is described by Gates and Jacobsen $(25 \cdot 6 \cdot 1)$, and has been modifled by fiansen $(32.6 \cdot 5)$. This cell has received wide acceptance for use in experimental work.

A flotation test is usually carried out as follows: A weighed amount of ore is crushed to 4 to $20 \mathrm{mesh}$, and ground with water and certain reagents in a laboratory ball mi11. The pulp is then transferred to the flotation cell, and water is added to give the desired ratio of ore to water. Frothing and other reagents may now be added, and the cell set in operation. the mineral rising into the froth is scraped off, or overfiows, and is recovered as concentrate. lailings and concentrate pulps are filtered, and their solid content dried, weighed, and assayed for various metals. the recovery of a given metal is reported as the percentage of that metal present in the charge, which is recovered in the concentrate. 
More complete details of flotation testing methods and apparatus are described by Dietrich, Engel and Guggenheim $(37.13 .2)$.

For the results of flotation tests on a wide variety of natural ores, reference should be made to the publications "Investigations in Ore Dressing and Metallurgy" published annually by the Department of mines, Ottawa, Canada.

\section{Floatability of Iure Minerals (Inherent Floatability)}

Although it has been shown repeatediy that clean minerals do not make contact with an air bubble under static conditions, it has not been conclusively demonstrated that minerals, under actual flotation conditions, have no inherent floatability. the conflicting conclusions reached by various workers depend, in part, therefore, upon their experimental approach to the subject of inherent floatability.

Investigators who have measured the contact angles developed by an air bubble on a mineral surface $(30.3 .1)$ $(33.8 .2)(34.3 .2)(34.3 .6)$ agree that no contact is developed if the mineral surface is clean.

Gaudin, (32.25.5), summing up the results attained in actual flotation practice, and in small scale tests, gives a table of inherent floatabilities of pure minerals. He considers that metals are the most floatable; then, in order of decreasing floatability: intermetallic compounds; sulfides of metals nearest sulfur in the periodic table; sulfides of metals furthest from sulfur in the periodic table; non-acid- 
forming oxides of the metals nearest to the dividing line between metals and metalloids in the periodic table, and that the least floatable compounds are compound oxides, and oxides of the metals far removed from the dividing line between metals and non-metals in the periodic table. He states that graphite and sulfur have inherent floatability, and xanthates do not function as collectors with these minerals. Rey (35.17.1) substantially agrees with Gaudin in contending that sulfur, graphite, talc, and molybdenlte will attach to an air bubble in the absence of any organic reagent.

Ravitz and Porter (34.3.1) report that they were able to float pure, unoxidized galena in a nitrogen atmosphere, in the absence of reagents, this supporting the idea of inherent floatability. they state that air will displace water from a pure galena surface, in direct contradiction to the work of laggart $(30.3 .1)$ and Wark and Cox $(34.3 .2)$

\section{Effect of various keagents on the kecovery} of Minerals in the Presence of a collector

Galena

Galena, when pure and unoxidized, according to Gaudin, (32.25.5) floats readily without a collector; a frother only being required. If the galene is oxidized, increasing amounts of collector are required to produce the same recovery, depending on the extent of oxidation. These observations are confirmed by other workers (34.3.1)

Kellermann and Bender (30.12.2) note that fresh xan- 
thate solution barely floats galena, but becomes effective on standing, or on treatment with sulfuric acid, and conclude that flotation is effected by xanthate hydrolysis products. Flotation tests made in a $50 \mathrm{gram}$ cell $(25.6 .1)$ in the laboratories of the American cyanamid company (27.2.1) showed that pure, dry-ground galena gave equal recoveries with pine-oil and potassium ethyl xanthate; and with phosphocresylic reagent, but poorer recoveries with thiocarbanilid o-toluidine mixture (TT mixture), for the same reagent concentration.

Pyrite

Equal recoveries of pure pyrite are obtained with pineoil-potassium ethyl xanthate, phosphocresylic reagent, and IT mixture, in the pH range 5.0 to 5.2 (27.2.1).

Gaucin $(32.25 .5)$ notes a poor recovery of pure pyrite with methyl quinoline, but better recovery of pyrite than chalcocite, when both minerals are present; due presumably to the activation of pyrite by copper ions derived from the chalcocite.

Pure, clean pyrite is easily floated, and oxidation inhibits flotation, according to Gaudin et al (28.19.1-Part 2). Gaudin notes, further (32.25.5) that pyrite is floated more readily by higher xanthates than by lower; and more readily by xanthates than by mercaptans. Using amy xanthate as collector, Gaudin (29.10.1) found that the re-

$$
\text { 1. Probably } \quad \mathrm{S}: \mathrm{P}: \frac{\mathrm{O}}{0 . \mathrm{C}_{\mathrm{SH}}} \mathrm{C}_{6}^{\mathrm{H}} \mathrm{H}_{4} \cdot \mathrm{CH}_{3}
$$


covery of pyrite was zero if the pH was above a critical value between 6.4 and 7.0 .

sphalerite

Most workers agree that potassium ethyl xanthate does not collect sphalerite until the mineral has been activated, by copper sulfate, for example $(28.19 .1)(30.3 .5)$. Kesults of Buchanan and Christmann $(27.2 .1)$, who find high recoveries of pure sphalerite with various collectors, including potassium ethyl xanthate, are explained by assuming traces of copper sulfate were present whlle the tests were made. Gaudin $(32.25 .5)$ considers pure sphalerite is one of the most difficult sulfides to float, and states that collectors with less than five carbon atoms in their hydrocarbon chain do not collect sphalerite, unless used in large amounts. The following list of collectors for pure sphalerite is given: di-iso-amyl ammonium al-iso amyl dithiocarbamate; xanthates higher than hexyl xanthate; trithiocarbonates higher than propyl tolthiocarbonate; certain amines such as monoisoamylamine; and certain hydrazines such as phenylhydrazine.

sphalerite recovery is an optimum at a certain pH for each collector studied $(28,19.1)$. This has been explained $(32.8 .1)$ by as suming that the maximum recovery zones correspond to pir bands of maximum reaction velocity between collector and mineral.

Kraeber $(30.25 .2)$ Iinds that maximum recovery is attained at pH 6 to 7 ; and that the optimum pH decreases as 
the iron content of the sphalerite increases.

- Hotation tests made by Yamada and Naganuma (36.25.7) indicate that sphalerite is not floated at a pH above 7.6 . Chalcocite

Flotation tests made by Gaudin and Sorenson (28.19.1) show that the activity of collectors for chalcocite increases as the non-polar part of the molecule is made more complex, and that aliphatic sulfides and disulfides are more active than aromatic sulfides and disulfides, but that the converse is true for the hydrosulfides.

De witt, Makens and Helz (35.1.1) correlate the surface tension of nornal xanthate solutions, from ethyl to heptyl, to their collector activity, as referred to chalcocite and malachite.

Gaudin mentions methyl quinoline $(32.25 .5)$ and monoisoamylamine (29.10.1) as collectors for chalcocite Chal copyrite

Gaudin (32.25.5) states pure chalcopyrite, if unoxidiged, is readily floated, with a frother only.

The recovery of chalcopyrite decreases from $96 \%$ to $84.4 \%$ through the pH range 10.42 to 11.76 , according to ramada and associates $(36.25 .6)$

Miscellaneous Sulfide Minerals

Yamade and associates $(34.25 .5)$ find that complete flotation of pyrrhotite is possible with camphor blue oil and coal tar in the pH range 4.6 to 5 ; but that floatability is negligible at a pr greater than 5 . 
Recent tests made by the same authors show that the recorery of arsenopyrite is decreased from $88 \%$ at a pH below 5 to zero above pH $5(36.25 .1)$; that enargite gives low recoverLes above pH $6(36.25 .2)$; and that the optimum recovery of stibnite is attained in the $\mathrm{pH}$ rango 4 to $6.5(37.25,3)$. The recovery of marmatite is decreased from over $60 \%$ to $2 \%$ as the $\mathrm{pH}$ is increased from 5.7 to $12(3 \%, 25.2)$ oxidized Minerals

The oxidized minerals which are considered, in particular, are azurite and malachite (basic copper carbonates), cerussite (lead carbonate) and anglesite (lead sulfato). In generel, oxldized minerals are less readily floated than the sulfides.

Malachite and azurite $(32.25 .5)$ are collected by higher fatty aclas and soaps, which separate the minerals from quartz, but not from calclte.

There is an optimum $\mathrm{pH}(28.19 .1--\mathrm{T}$. P.9) for the flotation of cerussite, of 9.0 with potassium amyl xanthate, and 7.8 with thiocresol. Gaudin $(32.25 .5)$ states that cerussite and anglesite are floated by soaps; and may bo separated from a s1liceous gangue by fatty aclds. Cerussite is collected by thlonaphthol and by amyl zanthate, but not by methyl xanthate.

Plumbojarosite $(32.25 .5)$ can not bo sulfidized, is not collected by ethyl or amyl xanthates, but is collected by n-octyl and n-lauryl xanthates if these reagents are used In large amounts. 
Non-metallic minerals

- Graphite and sulfur are readliy floated. An Instance Is reported (21.19.1) of the flotation of sulfur with amyl alcohol as the only reagent. Gaudin (32.25.5) does not belleve that xanthates exert any collecting action on sulfur or graphite. The rocovery of sulfur is affected by the $\mathrm{pH}$ (30.6.1). A pH of 7.5 to 8.0 has been suggested as an opt1mum range.

In contrast to the view that graphite has inherent flotablilty is that of Wark and $C O X(35.8 .1)$ who find that $a$ high concentration of frother (which has graphite collecting power) is required to float graphite. They note that certain frothers are Ineffectlve as collectors, and conclude that graphite requires a collector, such as a xanthate, for flotation. Confimatory work $(37.8 .1)$ in which it is found that amyl and ethyl xanthates increase the floatablilty of charcoal, leads Wark and Cox to conclude that the flotation of graphite, obtained in their previous work, was not due to metaliic impurities in the graphite.

Although sulfur usually floats without a collector, Wark and Cox $(35.8 .1)$ show that the presence of a collector enhances its flotation.

Berl and as soelates $(23.23 .1)(24.12 .1)(24.12 .2)(24.12 .3)$ have studied the flotation of tarious minerals, particularly artiflclally prepared silica, by the use of dyes, which, by adsorption on speclfic minerals, make them hydrophobic and cause the mineral to float. 
The effoct of soluble metal salts on quartz flotation has been Invest1gated by Kraeber and Boppel (34.9.1), who advance the theory that a complex is formed between the salt cation and the oxygen of the mineral surface, and that the character of the complex and lts flotation effect depend on the pH of the salt solution.

The flotation of non-metal11cs, particularly with regard to past and present practeo, ls extensively reviewed by Ralston (37.5.1). A b1bllography containing 126 reforences to this phase of flotation is appended.

\section{Specific Effects of Collectors on Minerals}

Gaudin $(34.3 .5 A)$ recap1tulates the known effects of xanthates in lncreasing the floatablilty of minerals, as follows: They aro without effect on s111cates, s111ca and gangues generally; In small amount they Increase the floatab111ty of copper, lead, s1lver, Iron, and mercury sulfides, and of elemental copper, silver and gold. They Increase the floatabl11ty of zinc sulfides only when the mineral is Ilrst activated, as by copper sulfate. In large amounts they Increase the floatabll1ty of oxidized lead and copper minerals; and of oxldized zinc minerals only when the xanthate contains a long-chain hyarocarbon group. Iron oxides and carbonates are not floated by xanthates. Sulfides of not typlcal1y metal1ic elements (stibnlte, roalgar, molybdenite) are not made to float markedy better by xanthate treatment. 
Gaudin $(32.25 .5)$ notes the selective action of certain collectors for specific minerals, and gives the following 11st: Sosps cellect the minerals of all di- and tri-valent metals, and minerals of certain monovalent metals such as silver. The lower xanthates collect copper, lead, lron, silver and mercury sulfides to the exclusion of the sulfides of zinc, calclum, barlum and aluminium. Xanthates collect lead minerals in preference to copper or mercury minerals. Substituted dithiophosphates select copper minerals. Al1phatic mercaptans select copper, s1lver and mercury minerals.

\section{Influence of Temperature on Floatablilty}

Huber-Panu (31.9.1) states that each ore and method has an optimum flotation temperature between $23^{\circ}$ and $40^{\circ} \mathrm{C}$. As the temperature is increased the time of flotation is deoreased, and the total recovery is increased up to a certain polnt. It is supposed that the decrease in recovery above this point is due to increased oxidation of the mineral, and Increased solubility of the compounds formed at the mineral surface. 
EXPERIMENTAL EVIDENCE FOR THE REACTION OF COLLECTORS

WITH MINERALS
$\frac{\text { Changes In a Collector Solution in Contact }}{\text { WIth a MIneral }}$

Considerable study has been made of the changes in a collector solution when it is brought into contact with a mineral. Experimental methods usually consist in agitating the solution with a known welght of sized mineral, for a given time, and determining, by analytical methods or sur. face tension measurements, any changes resulting in the collector solution. If a change In coicentration of collector results, the collector is sald to be abstracted by the mineral.

Abstraction, in general.

The first work dealing with abstraction of flotation reagents by minerals was probably that of Fahrenwald (21.25.1) who found, by measuring the surface tension of an oil-water emuision or solution before and after bringing it into contact with minerals, that all minerals investigated abstracted 011 from the emulsion or solution; that sulfides abstracted more than gangue minerals; and that, in general, the floatability of a treated mineral was proportional to the amount of 011 abstracted. He noted that electrolytes affect the amount of o11 abstracted. Taggart and Gaudin (22.3.1) made a similar study with confirmatory results. 
other workers $(33.8 .3)(32.8 .1)$ have noted a close connection between the abstraction of a soluble collector by a mineral and the solubility of the salt of the collector and the metal contained in the mineral. When the metal salt is relatively soluble, concentrated collector solutions and long treatment are necessary to effect abstraction.

Rimskaya (37.16.1) has studied the wetting 1sotherms of pyrite in sodium oleate; malachlte in heptyllc acid: galena in butyl xanthate solutions, and interprets them as showing two parts, the first corresponding to gradual saturation of a unimolecular collector layer; the second to a saturated flim, whlch shows the least wetting. Abstraction by galena

Taggart, Taylor and Knol1 (30.3.1) prove that there is a metathetical equivalence between the amounts of xanthate Ion abstracted from solution by galena, and the oxidation products of galena appearing in solution. They were unable to detect sulfide lons in solution, and suggest the mechan1sm of abstraction is purely chemical. Lead sulfide is oxidized to lead sulfate, whlch reacts with xanthate 1 on to form Insoluble lead xanthate. The fact that the ranthate abstraction is decreased by grinding and treating galena in the absence of alr, and increases with the time of exposure of galena to molst air, is taken to confirm this mechanism. Taggart, raylor and Ince $(30.3 .3)$ and Taylor and knoll (34.3.7) continued this work and found that the potassium concentration was unchanged, and that no lead lon could be 
detected in the solution after abstraction had taken placo. The necessity for oxidation of galona to precede reaction with the collegtor is confirmed by Ralston et al $(30.3 .4)$ Who found that galena ores, ground in tho absence of oxygen, gavo poor flotation results; and by WI kinson (35.9.1) who states that partial oxidation of galena is essential, if xanthate is to be adsorbed. Berl, Schmitt and Schulz $(33,12.1)$ note that oxidation of galena increases its collector requirements. In contrast to the above views is that of Revitg and porter (34.3.1) who flooted galena in the absence of air, and consider oxidation products on the surface inhibit plotation, and are not essential for the flotation of galena w1th ethyl xanthate.

Gaudin and Wiklnson $(33.8 .5)$ state that galena abstracts dixanthogen from an aqueous suspension.

It has been show $(28.9 .2)$ that the abstraction of capric acla from aqueous solution by galena follows the law:

$$
\begin{aligned}
\alpha=\beta c^{1 / n} & \\
\alpha & =\text { Welght abstracted } \\
c & =\text { equ1110rium concentration in } \\
\text { solution } & \\
\beta & =67 \\
\frac{1}{n} & =0.5
\end{aligned}
$$

and was further noted that dry galena shows leas adsorptive power than wet galena.

Ince $(30.3 .2)$ notes that galona abstracts more thiocarbanlild than sphalerite does. 
It has been shown that galena abstracts palmitate ion only from a solution of sodium palmitate, presumably to form insoluble lead palmitate $(29.25 .1)(29.15 .1)$ : and abstracts oleate lon from sodium oleate solution (34.3.6). Taggart (32.8.1) reviews the experimental work to date and notes that a-haphthylamine, potasstum ethyl xanthate, mono- and diphenyl thiourea, and $p$-thiocresol are abstracted by galene. Rimskaya (37.16.1) has studied the wetting lsotherms of galena in butyl xanthate. Abstraction by pyrite

It is stated $(34.3 .6)$ that pyrite abstracts only ethyl xanthate ion from a solution of potassium ethyl xanthate. Gaudin and Wlikinson $(33.8 .5)$ advance evidence to show that the xanthate, on abstraction, is changed to dixanthogen. Taggart (32.8.1) reviews the experimental work on abstraction and states that pyrite abstracts a-naphthylamine, potasgium ethyl xenthate, mono- and diphengl thlourea and p-thlocresol. Wark and Cox $(38.3 .1)$ were unable to determine the xanthate abstracted by cyanlde-treated pyrite, because reducing lons were liberated by the alkali present. By an indirect method however, they show that the depressant reduced, and probably prevented xanthate abstraction.

Abstraction by sphalerite

The non-abstraction of ethyl xanthate by pure sphaler1te has been noted by Taggart, Taylor and Knol1 (30.3.1) and confirmed by others $(30.3 .7)(33.8 .5)$, and is considered due to the high solubility of zinc ethyl xanthate (30.3.1) 
Abstraction of ethyl xanthate lon by copper-activated sphalerite has been measured by Gaudin $(30.3 .7)$, who finds It to be greater than the abstraction by cyanide-treated copperized sphalerite. Taggart states $(32.8 .1)$ that during abstraction of collector by copperized sphalerite, sulfate Ions appear in solution.

A very low abstraction of collector by cyanlde-treated sphalerite was noted by Ince $(30.3 .2)$, who also found that pure sphalerite abstracts less thiocarbanilid than galena does.

According to Berl, Schmltt and Schulz (33.12.1), who determined the amount of collector required to make a mineral hydrophobic, as shown by the inversion of a benzene-in-water to a water-in-benzene emulsion, the oxidation of sphalerite decreases its collect or requirement, by virtue of the high solublilty of zine sulfate.

Gaudin, Haynes and Haas (28.19.1 - T.P.4) showed that certain amines which float sphalerite, do not form insoluble zinc salts or sulfides.

Abstraction by chalcoclte

Chalcocite abstracts ethyl xanthate fon from a solution of potassium ethyl xanthate $(34.3 .6)$

Abstraction by chalcopyrite

The abstraction by chalcopyrite of various collectors, Including potassium ethyl xanthate, has been noted by Taggart $(32.8 \cdot 1)$. Gaudin and Schumann $(36.8 .3)$ found that chalcopyrite abstracts ethyl xanthate ion only, very rapldiy, 
from potassium ethyl xanthate solution, in quantity to form cuprous ethyl xanthate; and that hydroxyl, carbonate, sulfate, and reducing lons of the form $\mathrm{S}_{\mathrm{m}} \mathrm{O}^{-}$are thrown into solution, In total amount metathetically equivalent to the amount of xanthate ion abstracted.

Abstraction by sulfur and graphlte

In contradiction to Gaudin $(32.25 .5)$, Wark and Cox (35.8.1) show that a wide variety of minerals, Including sulfur, graphite, cerussite and gold, abstract xanthate from solution. The abstraction of ethyl and amyl xanthate from solution does not change the $\mathrm{pH}$ of the solution. In further work $(37.8 .1)$ they find that charcoal abstracts both anions and cations of potassium amyl and ethyl xanthates from solution; that more xanthate ion than potassium ion is abstracted; and that the difference is accounted for as an increase in the alkalinity of the solution. The abstraction of potassium ion probably takes place by exchange adsorption with hydrogen ions of the charcoal, and the increase in alkalinity by exchange adsorption of xanthate with hydroxyl 1ons.

Abstraction by miscellaneous minerals

oxidized minerals (malachite) abstract xanthate lons from solution $(32.25 .5)$, and adsorption isotherms of ethyl and butyl xanthates on malachite are given by Shneerson $(36.16 .4)$

The equivalence of the reaction between cerussite and

1. $\mathrm{PbCO}_{3}+2 \mathrm{EtX}-\mathrm{Pb}(\mathrm{EtX})_{2}+\mathrm{CO}_{3}^{--}$ 
xanthate has been shown by Gaudin $(34.3 .5 \mathrm{~A})$ by titrating the carbonate formed. Wark and $\operatorname{Cox}(36.3 .1)$ state that anglesito and cerussite astract sodium sulfide in preference to xanthato. Apatite removes palmitate ion from solution, as determined by surface tension measurements, presumably to form an insoluble calcium palmitate (29.25.1)(29.15.1). Cassiterite $(29.25 .1)$, which does not normally abstract palmitate ion, w11 abstract it from sodium palmitate solution after the mineral has been treated with calclum hydroxide.

Volkova et al (35.12.1) show that, in the flotation of talc by isovaleric acld, an exchange reaction occurs and magnesium passes into solution. Gaudin $(32.25 .5)$ states that certain sllicates, activated by metal lons, abstract soap collectors from solution. Volkova and Zaporozhetz $(35.12 .2)$ find that, In the flotation of certain finely-powdered nonmetallic minerals with isoamyl alcohol, adsorption of alcoho1, as evidenced by surface tension measurements, does not occur. Pootz (28.9.2) finds that quartz does not abstract capric acid from solution.

\section{Changes in a Mineral in Contact}

\section{With a collector solution}

Physical nature of coating

Visible coatings formed by collectors on varlous minerals have been noted. It is stated that visible coatings are formed on malachlte by treatment with zanthates $(34.3 .5 \mathrm{~A})$ on azurite by amyl xanthate $(28.19 .1)$, and on lead carbonate 
by xanthates, mercaptans and thiophenols $(32.25 .5)$.

- Fahrenwald (24.3.1) estimated the thickness of the ofl film formed on sulfides in 011 flotation was 10 to 100 molecules, but was greater if high concentrations of oll were used. The abstraction of various collectors by pyrite, malachite and galena $(37.16 .1)$ and copperized sphalerite (37.16.4), correlated to the amount of wetting, Indicates that maximum floatability is attained when a monomolecular film is formed on the mineral surface. Analysis or coatings on galena

When slightly oxidized galena, whlch has been treated with a zanthate, is loached with a solvent for lead xanthate, lead xanthate is obtalned in the leach liquid (33.25.3 through 32.25.5). on longer treatment with xanthate, sulfur and unidentifled olls are also leached from the surface $(33.8 .5)$. Gaudin $(34.3 .5 \mathrm{~A})$ belleves that, on long treatment, the lead xanthate which forms flrst, decomposes to sulfur and olls (probably dixanthogen), since the amount of lead xanthate recovered decreases with the time of treatment while the amount of sulfur and oils increases. Lead xanthate is also leached from the surface of galena treated with dixanthogen $(32.25 .5)$

Analysis of coatings on pyrite

Gaudin et al $(34.3 .5 \mathrm{~A})$ state that xanthates react with a pyrite surface to form ferric ranthate, which decomposes rapidiy to sulfur and an 011. For the latter reason, it is not usually possible to extract ferric xanthate from the 
mineral surface.

Analgsis of coatings on chalcocite

Guprous xanthate is extracted from the surface of chalcoclte which has been treated with an alkal1 xanthate $(34.3 .5 \mathrm{~A})$. Gaudin and schumann $(36.8 .3)$ leached xanthate-treated chalcoclte with water, and with pyridine. Leachlng with water had no effect on the floatability of the treated mineral. The pyridine extract contained cuprous xanthate, and probably small amounts of other substances. They conclude that the fliming of chalcoclte by xamthates is accompanied by reaction of part of the zanthate to form cuprous xanthate and other substances removable by organic solvents.

The coating formed by alxanthogen on chalcocite gives no tests for sulfur, dixanthogen, or o11, but shows the presence of varlous other products, presumably oxidation products of cuprous xanthate $(34.3 .5 \mathrm{~A})$ Analysis of coatings on miscellaneous minerals

Base metal xanthates have been identified by Gaudin $(34.3 .5 \mathrm{~A})$ in the visible coatings formed by xanthates on malachite and cerussite. Cowellite reacts with dixanthogen and alkell zanthates to form cuprous zanthat $\theta$ and sulfur. In the reaction with xanthates, dixanthogen is formed as an Intermediate product, $(34.3 .5 \mathrm{~A})$, and may be extracted from the coating.

Wark and cox $(35.8 .1)$ were unable to recover amy 1 zanthate from hot water or alcohol washings of treated graphlte: but obtalned an indleation of xanthate by an 
lodine titration of a suspension of treated graphite. Iaggart, del GIudice and ziehl $(34.3 .6)$ consider the formation of dixanthogen on minerals treated with xanthate as noted by Gaudin $(33.8 .5)(34.3 .5 \mathrm{~A})$ is not a significant factor in their flotation, since Wark and Cox $(34.3 .2)$ have shown that the characteristic contact angles for dixanthogen and xanthate are different, and that xanthate-treated galena gives the typical xanthate contact angle 


\section{GONTACT ANGLES AS A MEASURE OF FLOATABILITY}

\section{The Contact Angle}

When a gas bubble is brought into contact with a solla surface in a liquid, the bubble may become attached to the sol1d, or may fall to make contact. If attachment occurs, a definite angle is subtended between the plane tangent to the bubble and the plane of the solld surface at any point along the line of three phase contact. This angle, measured
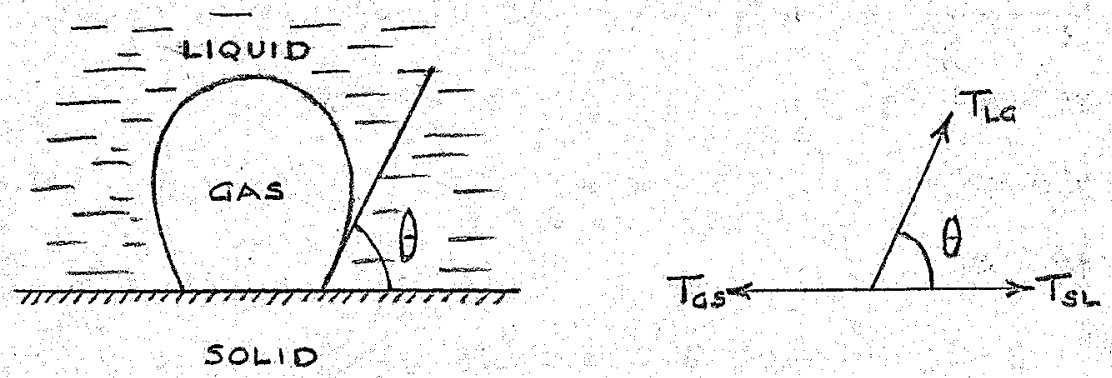

across the water phase, is called the contact angle. reinder's relates the contact angle to the interfacial tensions:

$$
\begin{aligned}
& T_{g s}=T_{s 1}+T_{1 g} \cos \theta \\
& T_{g s}=\text { gas-sol1d Interfaclal tension } \\
& T_{S 1}=\text { solid-11quid } " \text { " } \\
& T_{18}=1 \text { qu1d-gas } n \text { n } \\
& \theta=\text { contact angle }
\end{aligned}
$$

The "bubble machine", an apparatus for measuring contact angles, was introduced by Taggart, Taylor and Inco (30.3.3) and has been described in detall by del Giudice (36.6.1). A similar apparatus to that of Taggart is used 
by wark and $c o x(36.6 .2)$, who describe their machine, and give notes on the technique of operation.

\section{Signiflcance of the Contact Angle}

As \& Measure of Floatability

Taggart and Beach (16.3.1) used Reinder's equation as a qualitative gulde in expressing the relation between contact angles and flotation results.

Shepard $(32.10 .1)$ shows that the work to pull a bubble away from a solid surface $1 \mathrm{~s} \mathrm{~T}_{\mathrm{Ig}}(1-\cos \theta)$, and that, as a close approximation, collectivity is directly proportional to the contact angle. Wark (32.22.1) gives the quantity $T_{I g}(1-\cos \theta)$ as the free energy change $(-\Delta F)$ assoclated with bubble adhesion.

Wark and $\operatorname{cox}(32.22 .1)(33.8 .1)$, before using contact angle measurements as the major tool in their infestigations of flotation, made a thorough study of the signifleance of the contact angle, from a mathematical, thermodynamic, and practical point of view. They show that the contact angle is directly proportional to the force of air-solid adhesion, and is the best measure of the adhesion of a bubble of alr and alngle solid partiele.

del Gludice $(34.6 .3)$ reviews certain work on contact angles.

Valentiner $(36.9 .1)$ does not consider the contgct angle Is a measure of floatability, because the conditions under whlch it can be measured do not correspond to those in flo- 
tation.

\section{Effect of varlous factors on the contact angle}

The following results have been obtained by Wark and Cox, from an extensive study of contact angles $(33.8 .3)$ $(34.3 .2)(35.8 .1)(37.8 .1)(38.3 .1)$

Clean surfaces of all the minerals examined, Including galena, sphalerite, pyrite and pyrrhotite, do not develop contact with an alr bubble, in pure water.

on treating the mineral with a xanthate solution, if It then makes contact with the alr bubble, the magnitude of the contact angle is Independent of the mineral'; but depends only upon the non-polar group in the collector molecule? This is further evldence for the outward-orientation of this non-polar group at the mineral surface.

Certain sulfides make contact with alr in the presence of any xanthate. Other sulfides and xanthates require actio vation before contact develops.

Whether any contact will develop between an alr bubble

1. Metallic copper, various sulfieles, graphite, sulfur, and activated charcoal all show the same contact angle in a given ranthate solution.

2. For example: Diethyl dithiophosphate

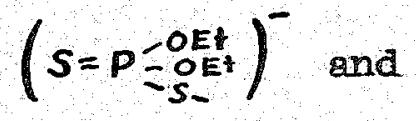
ethyl ranthate $\quad\left(S=C_{-S}^{-O E t}\right)^{-}$give the same contact angle because they have the same non-polar group. 
and a sulfide in a given ranthate solution, depends in general upon the solubility of the xanthate of the metal contained in the mineral! Sulfides whose metal constituents form relatively soluble xanthates, and gangue minerals, do not show alr-mineral contact in a xanthate solution.

In an homologous series of xanthates, the magnitude of the characteristic contact angle ineroases with the molecular weight of the xanthate.

For each mineral, in a given xanthate solution, there is a orltical pH above which contact is Impossible, and below whlch the full angle, characterlstic of the xanthate, is obtained. For a concentration of $25 \mathrm{mgm}$. per litre of potasslum ethyl xanthate, the critlcal pH values for galena and pyrite are about 10.2 and 10.5 respectively, at room temperature. As the concentration of a particular zanthate is Increased; or if a more complex xenthate is used at the same concentration, the critical pH becomes higher.

1. It was found, with the following collectors:

(1) sodium diethyl dithiophosphate

(2) potassium ethyl xanthate

(3) sodium diethyl dithlocarbonate

(4) Potassium isoamy I xanthate

(5) potassium di-n-amyl althiocarbamate

arranged in order of decreasing solubility of thelr heary metal salts, that chal copyrite responds to all five; galena and pyrite respond to all except the first; sphalerite responds to the fifth only. 
Anglesite responds to potassium ethyl xanthate best between $\mathrm{pH} 9$ and 11 ; cerussite at a pH less than 9. In the presence of soclum earbonate, a higher zanthate concentration Is necessary to produce contact with these minerals.

As the temperature $1 \mathrm{~s}$ aecreased from $35^{\circ} \mathrm{C}$ to $10^{\circ} \mathrm{C}$, the critlcal pH for galena, pyrite and chalcopyrite, in the pres ence of ethyl xanthate only, becomes lower. The following values are given:

$$
35^{\frac{C r i t i c a I ~ p H}{C}} 0^{\circ} \mathrm{C}
$$

$\begin{array}{lll}\text { Galena } & 10.8 & 9.7 \\ \text { Pyrite } & 10.7 & 10.0 \\ \text { Chal copyrite } & 12.7 & 10.9\end{array}$

Hysteresis of Contret Angle

Sulman noted $(20.25 .1)$ that contact angles show hysteresis, and consldered that flotation depends on this factor. Wark and cox $(34.3 .2)$ however, belleve that $h y-$ steresis of the contact angle $1 \mathrm{~s}$ due to friction. They were able to eliminate it in their experiments, and conclude that it does not help flotation.

\section{Time to Develop Contaet}

Freundil ch, ths In and IIndia $(33.25 .1)(33.25 .2)$ have studied the rate of wetting of minerals. They note that zinc sulfide and copper sulflde are wetted slowly; lead sulflde and Iron sulfide rapldy; and that olelc acla favors wett $\operatorname{lng}$.

sren Nilsson (34.12.1) correlates loatability to in- 
duction time (the time required, in contact angle measurements, for an air bubble to make contact with a mineral), and shows that collectors decrease this time, whllo depressors Increase 1t. Wark and $\operatorname{cox}(36.8 .1)$ comment on this work, and show that the induction time depends on the concentration of collector solution.

Methods for measuring wetting hysteresis in powdered minerals and ores are described by Klyachko (37.12.1), who observes a possible correlation between floatability and differential wetting hysteresis of a given powder, before and after adsorption of a wetting agent.

\section{Miscelleneous Contact Angle Invest1gations}

Contact angle studies made by Wark and Cox $(35.8 .2)$ with amines and sulfide minerals show that the maximum contact angle is independent of the amine; that copper minerals and activated sphalerite respond most readily; pyrite least readily to an amine; and that hexylamine allows sphalerite to be floated away from galena. They state that contact angle measurements closely parallel flotation tests.

Mokrushin and Demenev $(35.18 .3)$ have measured contact angles on metal sulfide films formed on a solution of the metal salt $(35.12 .4)$. They conclude that wetting of the flims is a temporary phenomenon, not explainable entirely by molecular orientation, but due also to lon adsorption from solution. Whey state that sulfide flims adsorb antons preferentially. 
Demeney $(36.25 .3)$ finds that xanthates do not change the wettability of sulfur flims formed by hydrogen sulfide on ferric chloside, which is taken to indicate that there is little or no adsorption. He was unable to obtain the constancy of contact angle clalmed by Wark and Cox. 
ELECTRICAL EFFECTS IN FLOTATION

Charge on Minerals, Alr Bubbles, and O11 Partleles

It has been shown $(14.25 .1)(22.25 .1)(24.25 .3)$ that a Ir bubbles and oll droplets in pure water carry an electric charge, that the number of free charges is very small (27.24.2), and that the origin of the charge is probably Ionic rather than electrostatic.

Ince (30.3.2) shows that, In similar aqueous solutions, certain minerals are positively charged; others negatively. Sven-N1Isson $(32.25 .6)$ states that alromineral adhesion Is good at high values of the potential measured by electrocapillary tests; poor at low values. The value of the potential at which the alr-adhering tendency of the mineral changes varies with the mineral.

\section{Potential of Mineral Electrodes}

The potentials of galena, copperized sphalerite, and glass electrodes, against a calomel electrode, have been measured by Kamienski and Benis $(37.16 .5)$.

\section{Ef fect of Reagents on Mineral Charge}

Kamienski $(32.25 .1)(32.25 .2)$ found that the potential of negative platinum, galena and graphite electrodes in potassium chloride solution becomes more negative; but that the potentigl of zine is unchanged, on adding terpineol and 
potassium ethyl xanthate to the electrolyte. lhis work was carirled out to test the theory that wetting of the electrode will reduce its positive charge. He suggests that o1l-sulflde adhesion is due to static phase-boundary potentials. Bull (29.24.1) determined the potential developed by galena, and by quartz, carrying initial positive and negative charges respectively, on falling through solutions of metal salts. It Is suggested that certain lons ralse the charge on galena and prevent 1 ts collection.

Both Iime and olelc acld reverse the charge on quartz, and potassium ethyl ranthate changes the sign on pyrite, according to 1 ilkhon $(35.25 .1)$.

The electro-kinetic potential of precipitated particles of metal ferrocyanides and sulfides increases during peptization $(36.25 .5)$. 


\section{THERMODYNAMICS OF FLOTATION \\ Heat of Wetting}

The heat of wetting of sillca was measured by Parks (02.25.1) and Edser (22.24.1). Fahrenwald (31.3.1) noted that the heat of wetting is an approximate measure of the adheston of a mineral to water, and Wark (32.22.1) showed, from a thermodynamlo treatment, that it is only a rough indication of the adhesive force, and that the contact angle is a better measure of this force. Recently $(37.25 .1)$ the heats of wetting by water, ethyl alcohol, and carbon tetrachloride, of powdered bartum sulfate and potasslum halides have been measured.

\section{Surface Energy}

Fahrenwald (31.3.1) has estimated the surface energy of quartz.

\section{Displacement Pressure and Adhesion Tension}

Barte 11 and associates $(27.11 .1)(27.25 .1)(33.8 .6)$ have developed a method for measuring the pressure of displacement of one liquid by another at the surface of a powdered solld, by which the liquid-solid adhesion tension may be evaluated. the adhesion tension of crude oils (28.11.1), various organic liquids and water $(32.8 .3)$ on sllica have been determined by this method. 
A relation between the lnterfacial angle and adhesion tension is glven by Bartell and Bartel1 (34.1.1), whlch allows, from one determination of the adhesion tension or contact angle of a liquid on a solid, the calculation of the adhesion tension of the solia on water or on any liqula whose interfacial tension against water is known.

Bartel1 and Greager $(32.8 .3)$ found that the adhes lon tension of various IIquias on $\$ 111 \mathrm{a}$, carbon black, and calelum fluoride is a Inear function of the absorbtion of the Ilquid by the solid, in those cases where 1 quid arops make zero contact angle on the sol1d; and that 011 absorbtion is Iow if the adhesion tension is high, or if the contact angle Is large. It is stated $(32.11 .2)$ that aqueous solutions whlch are most effective in displacing crude oll and benzere from sllica are adsorbed on, or react chemlcally with the s111ea.

If the various 11 quids studied $(33.8 .6)$ are arranged In the order of increasing adhesion tension against $\$ 111 \mathrm{ca}$, It is found that this serles is the reverse of the series for carbon; and that, for any given 1lquid, the sum of the adhesion tension on s111ca and the adhesion tension on carbon is approximately constant.

The adhesion tension of 11 quias $(34.8 .2)$ against strongIy hydrophilie solias is lndependent of the solla used. From this it is concluded that the sollds are covered by an adsorbed water flim.

Aahesion tension stuales of stibnite $(34.8 .3)$ ana 
galena $(35.8,3)$ indicate that the former changes slowly from a hydrophilic to an hydrophobic solld as it is subjected to successive Iimited oxidations, and that tho latter is elther an organophille or hydrophilic solld, depending on whether It is first wetted by an organic Iiquld, or by water.

The rate of displacement of water by pine oll from mineral surfaces has been measured by Barsky and Falconer (31.22.1), following the method of Barte11 (27.1.1.1)(27.25.1). They found that reagents which produce flotation cause the 011 to displace the water, whereas depressants have the reverse effect. Wark $(32.22 .1)$ discussed this work and criticlzed the conclusions.

David and Curt1s (32.11.1) have also studied wetting of minerals by water and organic compounds.

\section{Contact Angle as a Thermodynamic Quantity}

Wark (32.22.1) glves the following relationshlps:

$$
\begin{aligned}
-\Delta F & =T_{I_{g}}(1-\cos \theta) \\
\Delta F & =\Delta H=T \Delta S \\
\Delta S & =\left(\frac{d(\Delta F)}{d T}\right)_{D} \\
T_{I_{g}} & =11 \text { qu1a-gas Interfaclal tension } \\
\theta & =\text { contact anglo } \\
\Delta H & =\text { heat of wetting }
\end{aligned}
$$




\section{MISGHLLANHOUS STUDIES OF WETTING}

Agnes pockels $(33.12 .2)$ noted that the readiness with which a solid is wet by water decreases after drying. Metals and metallolds, crushed under water and then brought to the surface, exhlbit cortain water-repelient characteristics, according to Devaux (33.25.5)

Iuyken and Blerbraver $(29.25 .1)$ measured the wetting of minerals by the contact angle formed at a arop of sol. ution on the mineral surface.

Bartel1, In connection with his work on adheslon ten. sion of Ilquids against solias, has determined the contact angle formed by liquid drops on solid surfaces (29.11.1) $(32.8 .3)(34.1 .1)(35.8 .3)$, and has studled the wetting characteristics of talc, waxes and resins (36.1.1) by this technique. He found that water and organic liqulds form contact angles on talc, waxes and resins, and coneluded that the surface tension of these sollds is low. He states that sollas which are soft and have a low surface tension are wetted less readily by liquids than hard solids of higher surface tension. 


\section{THEORIES OF COLIECTOR ACTION}

\section{Introductory}

Several theories of collector action have been proposed. Most workers now agree that the collector or collector ion is removed from solution by the mineral, with consequent alteration of the mineral surface to make it more hydrophoble. The mechanism of the alteration is not agreed upon. It is thought to be elther metathesis between negative Ions of collector and positive lons from the mineral; or ad. sorption of an unspecifled nature.

\section{Chemleal Theory}

What has become known as the chemical theory of flotatIon was Introduced by Taggart, Taylor and Knoll (30.3.1), and amplifled in later papers by Taggart and his assoclates $(32.8 .1)(34.3 .6)$. In the first paper the generalization is made that soluble collectors roact with minerals by metathesis between mineral catlons and collector anions; and that the formation of a water-repellent flim on the mineral makes 1t flotable, while the formation of a water-avid flim makes It non-floatable. It is further stipulated that the reaction of a xanthate with galena requires previous oxidation of the galena to form lead sulfate. This mechanism was verlfled by the stolchlometric balance between the xanthate ion abstracted by the galena and the lons, derived from galena, which 
appear in solution; by the non-change in potassium ion concentration in solution; by the non-detection of sulfide ion in solution; by the recovery of lead xanthate from the surface of treated galena; and by the poor floatabllity of fresh galena.

opponents of the chemical theory, however, have noted that the floatability of anglesite (natural lead sulfate) Is less than the floatability of galena; that certain minerals such as gold $(34.3 .1)(33.8 .3)$, sulfur and graphite (35.8.1)(37.8.1), whlch do not lonlze in the usual sense, are collected by xanthates; and that xanthates are more soluble than the corresponding sulfides, rendering improbable the suggested reaction in which a sulfide is replaced by a xanthate. Iaggart $(34.3 .6)$ does not belleve that gold flotation disproves the chemical theory, as he was unable to float pure gold until it had been treated by á dis solving agent; presumably to provide gold lons required by the chemical theory. He explains the activating effect of sodlum hydroxide on cassiterite, and of sulfides on oxides, as being due to similar effects.

Cox and Wark $(33.8 .2)$ contrasted the chemlcal theory to adsorption theories, and pointed out that a true chemical theory implies adsorption can only occur when the solution is saturated with respect to the adsorbed compound.

Gaudin $(32.25 .5)(34.3 .5 \mathrm{~A})$ takes an intermediate stand. He belleves that chemical reaction is responsible for the collection of some minerals, $(\theta .8$. azurite by amyl xanthate, 
which forms a visible coat); that metathesis is the mechanism, at least in part, for collection of galena, chalcocite and covellite by ranthates; but that the original reaction is followed by decomposition or oxidation of the coating, so that the coat during flotation may or may not be base metal xanthate. He states that collection of sphalerite by phenjl hydrazine, and mono-isoamyl amine; and of chalcocite by monois oamylamine and methyl quinoline is not explainable on the basis of Insoluble compound formation.

A mechanism for the flotation of pyrite, In accordance with the chemleal theory, 1s stated by Taggart et al (34.3.6): Pyrite is oxidized to ferric sulfate; which, by metathesis with xanthate ion, forms ferric xanthate.

\section{Adsorption Theory}

Fahrenwald's early work dealing with oll flotation (24.3.I) led him to belleve that the heteropolar olls used as reagents were adsorbed, possibly as orlented films, on the mineral surface, and that adsorption took place when the mineral particles and 011 droplets carried unlike charges. As early as 1921, kyskewltsch (21.25.2) stated, "the difference of adsorption on gangue minerals and metallic minerals Is due to difference of structure. The space lattice of gangue minerals is made up of molecules; that of metallie minerals of atoms. Ihe metall1e minerals therefore have a residual valence or unbalanced static force at the surface which 1 s responsible for adsorption". 
Berl and associates $(23.23 .1)(24.12 .1)$ were able to float quartz by the use of dyes, and conclude that adsorption of the dye at the mineral surface forms a hydrophoble coating which renders the mineral floatable. They state that there is no relation between the sign of the charge on a mineral and its floatability.

Gaudin $(28.3 .1)$ postulated that santhates adsorbed at mineral surfaces to form non-Dalt onlan compounds. Schaum and assoclates $(32.12 .3)$ stated that collecting action is due to Ionic adsorption. Bartel1, Miller and Almy (33.1.1) discussed the appllcation of the Glbb's adsorption theorem. to solid-11quid interfaces.

Adsorption of the collector at a mineral surface is thought by Cox and Wark $(33.8 .2)(34.3 .2)$ to result in a closely packed film, with the alkyl groups orlented outward. Gaudin (34.3.5A) discussed the adsorption theory, and noted that there is doubt as to whether the adsorbed entity is xanthic acld or alkall xanthate molecules; xanthate ion; base metal xanthate molecule; or xanthate oxidation products. Adsorption theories, in general, have been criticlzed by Taggart ond associates $(34.3 .6)$ as not explaining the unchanged potassium ion concentration, or the recovery of lead ranthate from treated minerals. Their conception of adsorption is based on the Gibb's equation.

De Boer and custers $(34.25 .4)$ have attempted to calculate the energy of adsorption by considering it to be the sum of the van der Wal's and electrostatic forces. They 
show that molecules with a high dipole moment are largely adsorbed electrostatically, while van der Wal's forces act. with the non-pelar portion of the adsorbed molecule. Wark and $\operatorname{cox}(35.8 .1)$, on the basis of this work, consider that the unbalanced forces, particulariy electrostatic forces, at solid surfaces, act either on dipoles or dissoclated lons of the collector; since collectors have elther a high dipole moment, or a high degree of dissociation. Specifically, on graphite, xanthate lon is adsorbed with a surrounding layer of potassium ions, and every second carbon atom of the gra phite surface, carrying an unshared electron, should be able to adsorb a ranthate ion. They consider that the force binding ethyl ranthate ion to lead sulfide is stronger than that binding it to lead ethyl xanthate, and that the concentration of xanthate ions in oquilibrium with such different surfaces must $21 \mathrm{so}$ be different.

\section{Ostwald's Theory}

Wolfgang ostwald $(32.12 .1)$ introduced the concept of "Iinear" flotation, which involves a three-phase (air-vatermineral) Ilnear contact; as contrasted to oil flotation, thich Involves only a two-phase (011-mineral) contact. He states that film flotation uses diphllic collectors such as olele acid, while "linear" plotation uses triphlic collectors. A triphilic collector contains a capillary active group, and groups with affinity for metal and for water respectively. He stated that ethyl dixanthogen is not a collec- 
tor, because of the absence of a hydrophllic group, whllo carbanille and thlourea lack capillary active groups.

Evidence in support of ostwald's Theory is adduced by King (33.12.3) from observations with nickel dimethyl and aphengl glyoximes and galena.

ostwald's Theory is contradicted by photographle evidence $(32.12 .2)$ which shows that the mineral, as such, does not extend into the air phase. The compounds stated by ostwald to be non-collectors, are collectors in alcoholle solution. Wark and Cox $(33.8 .4)$ have also critlcized ostwald's Theory.

\section{Electrical Theorles}

Early explanations of flotation (15.25.2) (16.25.1) (17.25.1) considered that air-mineral adherence was due to different electrical charges on these phases. Gaudin (32.25.5) belleves, however, that the eariy investigators confused the electrostatic charge on minerals with the charge due to the Helmholz double lajer, which exists around a1r-bubbles, and notes that the existence of electrostatic charges on particles in an ore pulp presupposes the pulp is a delectric, which is not the case.

Fohrenwald (24.3.1) believed that selective oling of a mineral was the result of favorable electrical charges on the 011 and on certain mineral particles, and that flotation could be controlled by regulating the charge. He correlated flocculation and peptization, as Indications of the relative 
chargo carriod by the particles, to flotation and depression respectively. RIdsdale Ell1s (US Pat. 1,425,185) agrees with Falirenwald, and considers the function of chemical reagents 18 to control the sign of the charge on particles. Previous correlation between flocculation and flotation had been noted by SuIman (20.25.1), Edsor (22.24.1) and Bartsch (24.25.1). Ralston and Barker $(31.22 .3)$ commented on the effect of collectors on flocculation in practical flotation. Fahrenwald (31.22.4) advanced the facts that sphalerite is weakly peptized in water, strongly in allute sodium cyanide; quartz is peptized in water; copper sulphate flocculates a sphalerite suspension in sodium cyanlde as further evidence for the connection between flocculation and flotation, and between peptization and wetting.

Taggart, Taylor and Knoll (30.3.1) observed that particles in Brownian movement do not float; and noted that BrownIan mevement ean be controlled by the presence of reagents. These workers could not explain certain of their results by the kinetic theory. laggart, in a later revlew (32.8.1) however, offers an explanation for the previously observed effects of reagents on the Brownian movement, which is not In disagreement with kinetic theory.

Wark (32.22.1) believes that aispersion, as such, is no bar to flotation; but that the surface conditions which lead to dispersion also hinder flotation. Gaudin (32.25.5) takes the opposing vlew to Fahrenwald, Taggart, et al, and considers dispersion is necessary for flotation. He cites 
the practical use of dispersing agents (such as sodium silio cate) which produce cleaner concentrates and yield higher recoverles. In more recent work $(34.3 .6)$ Taggart conclúdes that flocculation is independent of flotation, but that particles In Brownian movement will not float because they are already wetted.

Tikhonor $(35.25 .1)$ noted that xanthate changes the sign of the charge on a mineral, but does not consider that electrostatic charges can account for all flotation phenomena. kecent work by Shneerson $(36.16 .4)$ shows that xanthates in crease the rate of flocculation of malachite suspensions; and that flocculation is due to adsorption, and firation of polar groups on the mineral.

\section{Miscellaneous Theorles}

Volkova $(35.12 .3)$ has explained the flotation of asbestos and barlte by assuming oriented coagulation of powder particles at a phase boundary.

Hel'd (35.16.1) distingulshed threo types of molecular attraction in flotation: (a) molecular adsorption (b) lonlc adsorption, and (c) chemical reaction. He states that the type is determined by the properties of the collector, and the elements of the mineral ergatal lattice.

Shvedor $(36.16 .2)$ advanced a modified chemical theory for the reaction of collectors with the products of semioxidation of minerals. 


\section{DEPRESSION}

A depressor is a chemlcal, used elther before, or in conjunction with a collector, to decrease the recovery of a specific mineral.

Acids and alkalis mey be classed as depressors. Their action, however, has been considered under the heading of the effect of $\mathrm{pH}$ on collector action.

sodium cyanide is used extensively to depress sphalerIte. Soluble chromates are used to lower the recovery of galena; and Ilme is sometimes emplojed to depress pyrite.

\section{EVIDENCE OF DEPRESSION OBTAINED FROM FLOTATION}

\section{TESTS AND PRACTICE}

Galena

The depressing effect of various cations (28.19.1-TP. I) (29.8.1) on galena, which decreases through the series: $\mathrm{Cr}^{3}, \mathrm{Th}^{4}, \mathrm{Al}^{3}, \mathrm{Cu}^{2}, \mathrm{Fe}^{3}, \mathrm{Hg}^{2}, \mathrm{Hg}^{1}, \mathrm{Ag}^{1}, \mathrm{~Pb}^{2} \mathrm{Cd}^{2}, \mathrm{CO}^{2}$, corresponds roughly to the insolubility of the sulfides formed by the cations. Gaudin (32.25.5) terms this class of depressant "toxic agents", because there $1 \mathrm{~s}$ no evidence of chemical reaction between reagent and mineral.

oxidized galena $(32.25 .5)$ is depressed by chromates, phosphates, tungstates, arsenates and arsenites. Compounds of lead with these anions are, In general, less soluble than either the oxidized coating on galena, or the lead salt of 
the collector used.

- Buchanan and Christmann $(27.2 .1)$ from flotation tests on pure galena specimens, using as collectors (1) pine o1l and potassium ethyl zanthate (2) phosphocresylic reagent, and (3) thiocarbanllid-o-tolulaine mixture; found that lime depressed galena with all three collectors, whlle sodium carbonate and eyanide were depressants oniy when using the third collector.

Trusor (35.16.2) found that galena is temporarily depressed by sodium hyposulfite, but not bo sulfite or thiosulfate.

Pyrite

The depressant action on pyrite of lime $(30.3 .4)$ and of sodium eyanlae $(30.25 .2)$ have been studied.

Buchanan and Christmann (27.2.1) found that lime strongly depresses pyrite at concentrations above $0.75 \mathrm{gm}$. per litre (pH 7.0 or higher); sodium carbonate up to $4 \mathrm{gm}$. per litre has little effect with the first two collectors; but at concentrations above $1 \mathrm{gm}$. per litre has a marked depressing action when used with the third collector; sodium cyanide is a strong depressant at concentrations greater than $1 \mathrm{gm}$. per Iitre for the first, and greater than $0.25 \mathrm{gm}$. per Iitre for the other collectors.

Brighton, Burgener and Gross (32.6.2) found that the depression of pyrite is proportional to the sodium cyanide concentration for a given size of particle. Smaller particles require a greater concentration of cyanide to effect the 
same amount of depression.

Pure Sphalerite - depression by cyanlde

Gaudin (30.3.7) found that sodlum cyanlde has no depressant action on wactivated sphalerite when reagents are used whlch collect unactivated sphalerite (e.g. amyl xanthate, thiocresol, amyl mercaptan), Wark and Cox $(34.3 .4)$ do not agree with Gaudin. According to Yamade $(36.25 .7)$ the effect of cyanide on the floatability of sphalerite is very 81 lght. Aetivated sphalerite - depression by cyanide

Flotation of sphalerite, possloly unintentlonally activated, was studied by Buchanan and Christmann $(27.2 .1)$, who found that soalum cyanide, at concentrations greater than 0.25 gms. per IItre, is a strong depressant. If sphalerite is Intentional1y activated by copper sulfate, more cyanide 1s required to cause deprossion.

Gaudin (30.3.7) showed that cyanlde completely depresses copper-activated sphalerite, bJ aissolving the copper sulfide coating and removing the copper ion from solution as undissoclated $\mathrm{Cu}(\mathrm{CN})_{3}^{-} 10 \mathrm{O}$

The depression by cyandde of sphalerito is less than thet of pyrite, eccording to Brighton, Burgeneriand Gross (32.6.2). pH as a fotor in depression was recognlzed by Gavain $(29.10 .1)$. Kroeber $(30.25 .2)$ has studied the Influence of cyanide on the floatability of zinc minerels. kecent work includes that of Mitrofonov and Arashkerich (36.16.1), and Mantser $(37.16 .2)$. The 1atter found that 
copper-activated sphalerite is completely depressed, as evidenced from wetting diagrams, by $0.005 \%$ sodium cyanide, when using potassium iso-amyl ranthate as collector. Sphalerite - depression by reagents other than cyanide

Pallanch (28.3.2) showed that soluble sulfites depress sphalerite, but not galena. Trusor (35.16.2) found that sphalerite is slightly depressed by sodium hyposulfite, but strongly depressed by its decomposition products: sulfites and thiosulfates.

Hellstrand (US Pat 1,469,042 - 1923) has patented the use of sodium sulfide as a depressor for sphalerite. sladkov $(36.16 .3)$, as a result of laboratory and plant tests on a Iead-zinc-copper-Iron-gold ore, considers sodium sulfice Is a better sphalerite depressant than eyanide.

Buchanan and Christmann $(27.2 .1)$ found that lime depresses sphalerite strongly with the first, silghtly with the second collector they studied; and that sodium carbonate depresses in the reverse order.

The depressant action of sodium carbonate and zinc sulfate has been investigated by Mitrofonov (36.16.1).

Mantsev $(37.16 .2)$, from a study of wetting diagrams, states that ferrocyanide does not depress activated zine sulfide, and that ferricyanlde is less effective than cyanide as a depressant. the action of ferricyanide is increased below $\mathrm{pH} 5$, and decreased above $\mathrm{pH} 9$.

Sphalerite is depressed by potassium dichromate $(500$ 8. per ton of ore) at a pH above 5.45 ; by tannin (500 g. per 
ton of ore) at a $\mathrm{pH}$ a ove 5.25 ; and by potass 1 um permanganate $(100 \mathrm{~g}$. per ton of ore); but ls not materlalIy affected by zine sulfate or sodium chloride $(36.25 .7)$

\section{Chalcoclte}

Tucker, Gates and Head (26.3.1) observed that chalcocite is depressed by cyanide in alkaline solution. According to Gaudin (32.25.5), chal coclte is depressed by thiosulfate, sulfite, sulfide, and ferro- and ferricyanide.

\section{Chal copjrite}

Chaj copjrite is depressed by oxldizing agonts, oyanide, sulflae, and 1 ime $(32.25 .5)$, but not by hyposulfite, sulfite, or thiosulfate (35.16.2). Brighton, Burgener and Gross (32.6.2) however, state that sodium cyanide, up to $11 \mathrm{~b}$. per ton of ore, has no depress Ing effect. Recent work of Yamada and associates $(36.25 .6)$ indloates that 893 g. potas sum cyanido per ton of ore, at pH 7.8 , causes a sudan decrease In the floatability of chal oopyrte.

Miscellaneous minerals

the work of Yamada and assoclates on arsenopjrite (36.25.1), enarg1te $(36.25 .2)$, mamatite $(37.25 .2)$ and stibnite (37.25.3), Indleates that arsenopjrite is depressed by copper sulfate bolow pH 5 , and by sodium sulfite, potasslum cyanide, zinc sulfate and tannin above about $p H 5$; that enargite is possibly depressed by cyanlde In alkallne sol. ution; that mamatite is depressed by zinc sulfate above pH 5.4, and is also depressed by tamin; that stibnite is depressed by copper sulfate in the pH range 3.5 to 7.0 , and 
by tannin in the range 6.2 to 7.2 .

Gaudin states that cerussite is depressed by alkali chromates $(32.25 .5)$.

Belash $(36.16 .5)$ finds that sodium sulfide depresses molybdenum in partially oxidized sulfide ores of molybdenum. Sulfidized malachlte $(37.16 .2)$, as evidenced by wetting alagrams, is completely depressed by cyanlae, but unaffocted by ferro- and ferricyanides. 
EXPERIMENTAL EVIDENCE FOR THE REACTION OF DEPRESSORS

WITH MINERALS

Changes in a Solution of Depressor in Contaet with a Mineral

(Abstraction of Depressor)

Galena

Galena does not abstract cyanide lon from solution $(32.6 .2)$ Pyrite

Pyrite abstracts eyanide in proportion to the soluble Iron prosent, and to the exposed mineral surface (32.6.2) Chalcopyrite

Chal copyrite abstracts more cyanldo than sphalerite, but less than pyrite $(32.6 .2)$

Sphalerite

The abstraction of cyanide from solution by sphalerite is greater than that by galena $(30.3 .2)$, but less than that by pyrite $(32.6 .2)$, since sphalerite is dissolved by sodium cyanlde $(30.3 .8)$. When sphalerite abstracts cyanide from solution, the concentration of sulfate ion in solution increases (30.3.1). The abstraction by copperized sphalerite is greater than by unactivated mineral $(30.3 .7)$.

Mokrushin and Villesove $(35.18 .2)$ found that copper sulfide films, formed on the surface of a copper sulfate solution, adsorb chloride ion from sodium chloride solution, and zinc lons from zinc sulfate solution. They believe that the latter ions are held as if a zinc atom had replaced a copper 
atom in the crsstal lattice; while chlorlde lons are held as If by true adsorption.

\section{Changes in a Mineral in Contact with a Depressor solution}

Tucker and associates $(25.3 .1)(26.3 .1)$ elalm that cyanido produces a vilble change on the mineral surfaces they invest1gated. Previous experlments (20.25.2), and later attempts to duplicate Iucker's findings $(30.3 .3)(30.3 .7)(28.9 .1)$ do not confirm the prosence of visible coatings. tucker and assoclates also claim to have analyzed the coating formed on sulide minerals by lime and ejanide.

Gaudin (32.25.5) states that chromates produce a $\nabla 1 s i b l \theta$ coating on oxidized, but not on fresh galena. 


\section{CONTACT ANGLE STUDIES OF DEPRESSION}

The results of contact angle moasurements, outlined below, are those of Wark and $\operatorname{Cox}(34.3 .2)(34.3 .3)(34.3 .4)$ $(36.3 .1)(36.8 .1)(37.8 .1)(38.3 .1)$, except where otherwise noted.

\section{Depression by Gyanide}

Galena

Cyanide, in the usual concentrations, does not affect alrogalena contact with any of the collectors studied. Pyrite - pure mineral

Cyanide lowers the eritical pH for pyrite. As the pH is increased, the eritical ejanlde concentration for pyrlte and chalcopyrite is decreased.

The cyanide concentration to prevent contact with pyrite and chalcopyrite, when using the following collectors:

1. sodium diethyl dithlophosphate

2. potassium ethyl xanthate

3. sodium diethyl dithlocarbamate

4. potassium isoamyl zanthate

5. potassium di-n-amyl dithlocarbamate (arranged in order of decreasing solubility of their heavy metal salts), Increases in the order I to 5 .

The concentration of cyanide to depress pyrite and chalcopyrite decreases slightly as the temperature is raised from $10^{\circ} \mathrm{C}$. to $35^{\circ} \mathrm{C}$. 
If trimethylcetyl ammonium bromide is used as collector, pyrite is not depressed by cyanide, but is depressed by copper sulfate usec with cyanlde; presumably by the effect of the cupricyanide ion.

Pyrite - In the presence of copper sulfate

If copper sulfate is also present, contact is similariy prevented by cyanide with all fivo collectors noted.

with ethyl xanthate, at a given $\mathrm{pH}$, the cyanide concentration to prevent contact with pyrite is less when copper sulfate is present; but with chalcopyrite, is greater.

Ihe concentration of sodium cyanide to prevent air-pyrite contact in the presence of copper sulfate and ethyl ranthate, increases rapidly with temperature to a maximum at about $35^{\circ}-40^{\circ} \mathrm{C}$. It is suggested, therefore, that the best separation of sphalerite or chalcopyrite from pyrite is effected at a low temperature and Iow xanthate concentration. sphalerite - pure

Pure sphalerite responds to potassium di-n-amyl dithiocarbamate and makes contact with an alr-bubble. If cjanido is added this response is prevented.

Mokrushin and Demener (35.18.1) have found that potassium cyanide decreases the contact nngle to zero at a zinc sulfide film on the surface of a liquid. Sphalerite - activated by copper sulfate

Cyanide makes copper-activated sphalerite non-responsive, and prevents activation of pure sphalerite by copper compounds unless the copper ion concentration is in excess of the ratio 
$1 C \mathrm{Cu} 3 \mathrm{CN}$.

- An Inerease in the pH Improves the action of cyanide. Temperature has. Ifttle effect on the concentration of cyanide required to depress copper-activated sphalerite.

When amyl xanthate is used as collector, in the presence of copper sulfate, and at a given pH, a greater concentration of ejanide is required to prevent contact, than when ethyl xanthate is used as the collector. The offect is greater if the $\mathrm{pH}$ is high.

Taggart and associates $(34.3 .6)$ noted that a sphalerit $\theta$ particle, showing no contact in a xanthate-cyanide-copper sulfate solution containing eyanide in excess of $3 \mathrm{CN}: 1 \mathrm{Cu}$ ratio, does not respond to xanthate after it is removed from the solution and washed.

If copper sulfate is present, the cyanide and/ore alkall necessary to prevent contact with sphalerite is proportional to the copper sulfate present.

In the presence of a collector, less cjanide is required to prevent activation of fresh sphalerite, than to deactivate sphalerite that has been previously activated. The amounts approach each other as collectors are used in the order 5, 4, $3,2,1$ in the serles given. With diethyl dithlophosphate, the amounts are equal. This suggests that more eyanide is required to remore the copper xanthate, than to remove the copper-bearing activation film from sphalerite.

If trimethylcetyl ammonlum bromide is used as a collector sphalerite is not depressed by cyanide, but is depressed by a 
mixture of copper sulfate and sodium cyanide; presumably by the cupricyanide ion.

Chal copyrite (see also Pyrite)

If copper sulfate is prosent, the amount of cyanide and alkall, used either alone or together, whlch is necessary to prevent contact on chalcopyrite, is proportional to the copper sulfate present. Temperature has little effect on the concentration of cjanide required to depress chalcopyrito in the presence of copper sulfate.

Mokrushin and Demenev $(35.18 .1)$ found that potassium cyanide decreases the contact angle to zero at a copper sulfide film on the surface of a liquid.

Miscellaneous minerals

Covellite is less sensitive to cyanide than is actirated sphalerite.

Marmatite, christophite and sphalerite, in the presence or copper sulfate, are equally senaltive to cyonide and/or alkali. Pyrrhotite is not activated by copper sulfate in the same manner.

Graphite and charcoal are unaffected by sodium ejanide, with ethyl xanthate as collector.

Tinstone is depressed by a mixture of copper sulfate and dodium cyanide, using trimethylcetyl ammonium bromlde as collector.

Arsenopyrite, $11 \mathrm{ke}$ galena, is unaffected by cyanlde in the absence of copper sulfate. In the presence of copper sulfate, the effect of cyanide is similar to its effect on pyrite. 
The contact angle at films of blsmuth sulfide formed on the surface of a liquid is decreased by potassium cyanide, and more strongiy decreased by silver nitrate, according to Mokrushin and Demener (35.18.1)

\section{Depression by Sodium Sulfide}

Sodium sulfide depresses sulfides. The concentration of sodium sulfide to prevent contact is a function of $\mathrm{pH}$. HS Ion is the effective depressant. There is a critical HS concentration for each mineral, just suffleient to prevent response to a given potassium ethyl xanthate concentration. The xanthate concentration does not greatiy affect the crit. 1cal HS concentration.

Copper sulfate influences the effect of sodium sulfide on chalcopyrite and galena, probably by removing the sulfide Ion as copper sulfide.

If trimethylcotyl ammonium bromide is used as a collector sodium sulfide does not depress sphelerite or pyrite.

\section{Depression by other Reagents}

Copper sulfate depresses pure pyrite, under certain conditions, with sodium dlethyl and potassium di-n-dlamyl dithiocarbamates.

S1Iver nitrate reduces slightly the contact angle on films of copper sulfide and zinc sulfide on the surface of a 11quid, according to Mokrushin and Demener $(35.18 .1)$ 


\section{Depression In General}

The amount, of cyanide, at a glven pH, to prevent contact with pure minerals, increases through the series pyrite, chalcopyrite, bornite, covellite, and chalcocite. If copper sulfate is also present, the order is pyrite, sphalerite, chalcopyrite. The resistance of a given mineral to depression by cyanide becomes greater as collectors are used which form more insoluble salts of the metal in the mineral.

The Influence of cyanide on copper and lron minerals appears to depend only upon the cyanide lon concentration. there is a critical cyanide ion concentration for each mineral, just suffieient to prevent contact. The pH of the solution, if below the critlcal value (see Gollectors Effect of $\mathrm{pH}$ on Contact Angle) is important only so far as It controls the cyanide ion concentration. If the $\mathrm{pH}$ is above the eritical value, contact is impossible, whether cyanide is present or not. 


\section{THEORIES OF DEPRESSOR ACTION}

\section{Depression by Cyanide}

According to Ince $(30.3 .2)$, cyanlde forms an insoluble metal eyanide on zine and iron sulfides with the water-avid cyanogen groups outer-oriented. He states that no simple cyanlde of lead is known, but this is not conflrmed by handbooks.

A theory of depression has been advanced by Berl and Schmitt $(30.12 .3)$. Christmann $(30.2 .1)$ and Buchanan (31.22.3A) belleve that complex cyanide lons are adsorbed by sphalerite, but may be replaced by copper. They also suggest $(27.2 .1)$ that pyrite $1 \mathrm{~s}$ depressed by complex iron cyanides formed by the reaction of cyanide and soluble iron.

Fahrenwald $(31.22 .4)$ believes that depression involves peptigation; and that eyanide forms a ainc cyanide film on sphalerite which does not react with the collector. The deslrability of making electro-osmotic measurements on sphalerite in the presence of sodium eyanide, to determine if it becomes more polar, 1s suggested by Buchanan (31.22.4)

Taggart (32.8.1) contends that depressors react with mineral surfaces to form adherent salts which are less soluble than the salts of the collector with the metal in the mineral. Gaudin $(32.25 .5)$ states that the effect of cyanide on pyrite may consist of coating the mineral surface, or In the solution of an activating copper film. Brighton, 
Burgener and Gross $(32.6 .2)$ conclude that eyanlde prevents metallic xanthate formation on the surfaces of pyrite and sphalerite, either by forming a preclpltate, a weak salt, or complex lon; or by dissolving an exlsting film of xanthate. Gaudin $(30.3 .7)$ states that depression of copper-activated sphalerite is due to solution of the copper-bearing coating to form undissoclated $\mathrm{Cu}(\mathrm{GN})_{3}^{-}$10ns.

laggart and assoclates $(34.3 .6)$ advanced the theory that cyanlde elther dlssolves the copper sulfide film on ac tlvated sphalerite or reacts with and removes the copper ion made avallable by oxldation. Because the concentration of cyanide to cause depression varles with the collector used, they state that removal of a copper suIflde film can not be the entire mechanlsm. They incline to the view that cyanide disolves a film of cuprous xanthato from activated sphaler Ite but also forms an insoluble zinc cyanlde coat on pure sphalerite. lhey also suggest that depression of pyrite by cyanlde involves coating the mineral surface with a momplex copper-iron eyanide, since depression, In contact anglo measurements, appears to be related to cupricyanide ion concentration.

Wark and cox $(34.3 .2)$ adduced evidence to prove that cyanide removes the copper compound formed on activated sphalerite, probably as a complex cuprocyanide; and that prevention of contact in ejanide solution is due to prevention of adsorption by the mineral of a film of collector, not due to formation of a cyanide film at the mineral surface. Thelr 
recent work, $(38.3 .1)$ Indicates that the combination of copper sulfate and eyanide is a more effective pyrite depressor than elther compound used alone, presumably by the action of a complex copper cyanide lon. The combination $1 \mathrm{~s}$ particularly effective at low temperatures $\left(10^{\circ} \mathrm{C}.\right)$

\section{Depression by Reagents other than Cyanide}

Chromates

Gaudin $(32.25 .5)$ believes alkall chromates depress cerrussite and galena by coating them with lead chromate, which Is less soluble than the existing coat on the mineral (e.g. Iead carbonate). In this was they cause the mineral to resist the action of colloctors. Taggart and assoclates $(34.3 .6)$ suggest a similar mechanism for the depression of galena by chromates, but postulate that the chromate nay also oxidize an exlsting colloctor film.

$\mathrm{IIme}$

Ralston $(30.3 .4)$ showed that pyrite roacts with Iime to form soluble sulfides and thiosulfates, which are then oxidized to sulfates. He considers that the oxidation products eause depression. Gaudin $(32.25 .5)$ suggested that 1 Ime may dissolve pyrite to some extent; at the same time coating the mineral with effective depressants.

Sulfites

Pallanch $(28.3 .2)$ believes that sulfites depress sphalerite in the presence of galena by forming a zinc sulfite coating on the zinc but not on the leat mineral. 


\section{Miscellaneous, Reagents}

- The action of reagents such as aluminium and chromiun salts in inhlbiting flotation is ascribed, by Gaudin (32.25.5) to hyorolysis of the reagent, with the formation of colloldal hydroxides which adhere indiseriminately to the mineral surfaces. 


\section{ACTIVATION}

An activator is a reagent, used with a given mineral and collector to cause the mineral, otherwise unfloated, to be floated by the collector.

The most common example of this class of reagent is copper sulfate, used as an activator for sphalerite. Ethyl zanthate does not collect sphalerite untll the mineral has been treated with an activator such as copper sulfate. In the soparation of galena from sphalerite, galena is first floated away fron cyanido-depressed sphalerite. Coppor sulPate is then added to activate the sphalerite and allow $1 t$ to be floated.

\section{EVIDENCE OF ACTIVATION OBTATNED FRON FLOTATION TESTS AND PRACTICE}

\section{Pyrite}

Although Gaudin $(32.25 .5)$ stated that pure pyrite is activated by soluble copper, contact angle measurements by Wark and Cox (38.3.1) Indieate that, under no circumstances, is pure pyrite activated by copper sulfate.

Recovery of pyrite, which has been depressed by Iime, sodium carbonate, or sodium cyanide, ls enhanced by copper sulfete with ethyl xanthate, but not with TT mixture or phose phocresyllc reagent as collectors $(27.2 .1)$. Depressed pyrite is apparent1y activated by soluble sulfides, or by an acia 
clrcuit $(32.25 .5)$

Sphalerite

The activation of sphelerite by copper sulfate has been studied bJ Buchanan and Chrlstmann $(27.2 .1)$ and by Gaudin and associates (28.19.1-TP 1 \& TP 7). The latter found that sphalerite is activated by salts of metals whose sulfides are less soluble In water than zine sulflde (e.g. s1lver, copper, mercury, eadmium, and lead); that copper sulfate widens the pH zones of highest recovery; and, with certain collectors, also Increases the recovery.

kalston and Hunter $(30.3 .6)$ noted that cuprous and cupric salts are equally effective activators. Ihey correlate the activating effect of a given metal Ion to the position of the metal in the electromotive series. From copper to s11ver, activation decreases. Lead, cadmium and zinc are depressors. they also noted that copper oleates, resinates and zanthates, when added as such to a flotation pulp, are non-effective as activator-collectors.

Mitrofonov and Arashkevich (36.16.1) have studied the effect of copper sulfate on the floatability of sphalerite. In the presence of copper sulfate $\left(500 \mathrm{~g}\right.$. CuSO $4.5 \mathrm{H}_{2} \mathrm{O}$ por ton of ore) sphalerite $1 \mathrm{~s}$ completely recovered in the pH range 1.3 to 11.65 according to Yamada $(36.25 .7)$

Miscellaneous sulflide minerals

oxldized sulfide ores of molybdenum $(36.16 .5)$ are getivated by treatment with copper sulfate followed by sodium sulfide. It is presumed that a copper sulfide coating is formed. 
Marmatite is activated by copper sulfate in the pH range 2 to 11; by zine sulfate if the pH is below 5 . Above pH 5.4 zinc sulfate ats as a depressor $(37.25 .2)$

Stibnite is activated by $\mathrm{PbO}(\mathrm{Ac})_{2}$ in the $\mathrm{pH}$ range 6.5 to $6.8(37.25 .3)$

oxidized minerals

Halachlte is activated by lead salts (28.19.1 - TP 9), cerussite by soluble sulfides $(32.25 .5)$, presumably by coating the mineral with lead sulfide. Non-metallic minerals

Calcite, activated by copper and lead lons, will respond to soap collectors $(34.6 .3)$. 
EXPERIMENTAI EVIDENCE FOR THE REACTION OF ACTIVATORS WITH MINERALS

Changes in a Solution of Activator in contact with a Mineral (Abstraction of Activator)

Varlous Investigators $(25.6 .1)(24.3 .1)(26.5 .1)$ have shown that copper sulfate is abstractod from solution by sphalerlte. At the same time a coating of copper sulfide is formed on the mineral and the concentration of zinc Ion in solution increases. The abstraction of copper sulfate by pure minerals $(30.3 .5)$ increases in the order: pyrite, chalcopyrite, schist, and sphalerite.

Ince $(30.3 .2)$ found that more copper sulfate is abstracted by cyanide-treated sphalerite than by the pure mineral.

The abstraction of metal lons from solution by silicates has been noted by Gaudin (32.25.5). Such metal-coated sillcates are activated towards a soap collector if the metal cost forms an Insoluble soap with the collector.

Changes in a Mineral in Contact with an Activator Solution

Rogers $(11.25 .1)$ and Tucker and Head $(25.3 .1)$ have observed visible coatings on copper sulfate-treated sphaler1te, but Ince (30.3.2), Mitrofenoff (28.9.1) and Ralston, et al $(30.3 .5)$ were unable to duplicate their results. Gaudin $(30.3 .7)$ found that sphalerite reacts rapidiy, at first, with eupric nitrate in acid solution to form a thin 
coating of cupric sulfide, but that the rate decreases with the time of reaction. He noted $(32.25 .5)$ that the coating formed on sphaserite by the action of copper sulfate is visible if high temperatures are employed. A visible coating (32.25.5) Is formed by sodium sulfide on cerussite. Although Wentworth $(10.6 .1)$ was unable to detect any surface alteration he found that the conductivity of sphalerite increased after treatment with copper sulfate.

It is generally cons1dered $(25.19 .2)(26.3 .1)(28.19 .1-$ TP 7) $(30.3 .5)(30.3 .6)$ that the coating formed by copper sulfate on sphalerite is cupric sulfide, sometimes referred to as covellite. Gaudin $(30.3 .7)$ stated that the coating has been shown to contain copper, and to be non-reactive toward silver nitrate. It is presumed to be covellite on the basis of the demonstrated reaction:

$$
\mathrm{ZnS}+\mathrm{Cu}^{++} \rightarrow \mathrm{CuS}+\mathrm{Zn}^{*}
$$

Taggart (32.8.I) takes an opposing view, apparently without presenting experimental evidence for the contention, that the coating consists of cuprous sulfide willoh is subsequent Iy oxidized. Because natural covellite is difficult to float, Beck (34.25.1) suggests that the film formed $1 \mathrm{~s}$ a mixture of cupric and cuprous sulfides and sulfur, rather than covelilte, and that free sulfur is the activator. Kamenetzi (34.25.2) found that $0.01 \mathrm{~N}$ silver nitrate reacts with such mineral surfaces as chalcopyrite, pyrite, galena, covellite, orplment, and sphalerite, to precipitate $\mathrm{Ag}_{2} \mathrm{~S}$ and throw sulfide into solution. 
Ravitz and wall $(34.8 .1)$, assuming that eopper sulfate forms cupric sulfide on sphalerite, found the concentration of copper sulfate to glve the best flotation recovery is that required to form a monomolecular film on the surface of the sphalerite. They noted that the abstraction from the solutions used in practice is in excess of this amount. on the basis of ZWicky's theory of mosale crystal structure $(29.25 .3)$ $(30.25 .3)(33.13 .1)$, they explain the fact that smaller particles require less copper sulfate than is requlred to form a monomolecular f1Im, In order to effect the same flotation recovery as attalned with large particles. 


\section{CONTAGT ANGIE STUDIES OF ACTIVATION}

The results of contact angle measurements, outlined below, are those of Wark and Cox $(34.3 .3)(34.3 .4)(36.3 .1)$ $(36.8 .2)(37.8 .2)(38.3 .1)$.

Copper sulfate activates sphalerite and activates galena above its oritical pH. It is without effect on the response of pure pyrite, graphite, or charcoal, to potassium ethyl xanthate. Copper sulfate is a more effective activator for sphalerite in neutral cyanide-free solution than in an alkaline solution contalning cyanide. Copper sulfate, in combination with eyanide, depresses, rather than activates pyrite.

Salts of such metals as platinum, gold, bismuth, mercury, silver, copper, cadmium, lead, cerium, antimony and arsenic, activate sphalerite, so that it will respond to potassium ethyl xanthate. Thallium and cobalt salts have a slight activating tendency, while salts of titanium and tin show none. In general, those metals which are effective activators form sulfides less soluble than zine sulfide, while the non-effective metals form sulfides which are more soluble. However, thallium sulfide is reported more soluble, and stannous sulfide as less soluble than zinc sulfide. These metals are apparentiy exceptions to the generalization. Sphalerite, depressed by sodium sulfide, may be activated by copper sulfide, if the copper sulfate is in stolch10metric excess of the sodium sulfide. Controlled concentrations 
of sodium sulfide activate anglesite and cerussite, presumably by coeting the minerals with a lead sulfide flim, so that they w111 respond to a lower concentration of zanthate. Excess sodium sulfide, however, prevents response. In certain cases sodium phosphate may be substituted for sodium sulfide as an activator for these minerals. 


\section{IHEORIES OF ACTIVATOR ACTION}

All theories for the activation of sphalerite by copper sulfato are basically the same. They postulate the formation, on the sphalorite surface, of a copper-contalning coat whlch wl1 react with the collector, whereas the unaltered sphalerIte surface does not react. The various theorles differ as to the composition of the coating, and the mechenism by which it $1 \mathrm{~s}$ formed.

Varlous theorles have suggested, on the basls of the reaction:

$$
\mathrm{ZnS}+\mathrm{Cu}^{+} \rightarrow \mathrm{CuS}+\mathrm{Zn}^{+}
$$

that the coating is cuprie oulfide. As polnted out by Ralston, KIng and Tartaron $(30.3 .5)$ however, the mineral covelIIte, which is cupric sulfide, is diffloult to float.

Mtrofanoff $(28.9 .1)$ suggested the formation, in an alkaline copper sulfate solution containing cjanide, of a coating of hydrate, cyanide or carbonate, followed by the formation of the corresponding copper compounds, which react with xanthate to form insoluble copper xanthato.

Ince (30.3.2) advanced the theory that an insoluble cupric cyanide is formed at the surface of cyanide-treated sphalerite. Cyanide lon $1 \mathrm{~s}$ thus removed, and frees the zinc of the mineral to react with the collector.

Taggart (32.8.2) contended that the cuprous sulfide coating first formed $1 \mathrm{~s}$ oxidized and then reacts with xanthate 
to form cuprous xanthate. Whe abstraction of xanthate ion, and liberation of sulfate ion is evidence for such a reaction. Tho activation of cyanide-treated sphalerite is thought to be effected by the decomposition of zine eyanide, accompanied by the formation of soluble cuprocyanide ions. Taggart and assoclates $(34.3 .6)$ alscuss activation in terms of the chemical theory.

Ralston, King and Tartaron $(30.3 .5)$ noted that the film formed by copper sulfate on sphalerite is probably different In nature from that on pyrite, because displaced zinc is soluble, whlle iron is insoluble in alkaline solutions. They consider that this difference may account for the fact that copper sulfate activates sphalerite to a greater extent than pyrito. 


\section{REFERENCES FOR BIBLIOGRAPHY}

In the accompanying list the references have been numbered, according to the following conventions: The first number Indleates the jear of publication; the second the journal In which the article is published, and the third is the soquence number of the reference to a particular journal and Jear.

The two numbers on the right hand slde of a reference refer to the volume and page of Chemlcal Abstracts, respectively. The key numbers used for varlous journals are as follows:

1. Journal of the American Chemical society

2. American Cyanamid Company Publieations

3. Publications of the American Institute of Mining and Metallurgical Englneers

4. Canadian Mining Joumal

5. Publications of the Canadian Institute of Mining and Retal lurgy

6. Engineering and Mining Journal

7. Economic Geology

8. Journal of Physical Chemistry

9. Metall und Erz

10. Mining and Metallurgy

11. Industrial and Engineoring Chemistry

12. Ko1101d Zeitschrift

13. Publications of the United States Bureau of Mines

14. Publications of Jtah Englneering txperiment Station 
15. Zeitschrift für technts chePhys 1k

16. Various Russian Publications

17. Congress intern. mines metal geol. appl.

18. Journal of Physical Chemistry (U.S.S.R.)

19. Publications of the University of Jtah

20. Mitt. berg. Huttenmann, etc.

21. Selence

22. Transactions of the Rlectro-Chemical society

23. Zeltschrlft für angewandte Chemie

24. Col1o1d Symposium

25. Miscellaneous Publlations

1835.25 .1

Ze1se

Ann, physik. Chem. Pogg. 35, 487; 1835

02.25.1 ON THE HEAT EVOLVED OR ABSORBED WHEN A LIQUID IS BROUGHT IN CONTAC'1 WITH A FINELY DIVIDED SOLID Parks, G.J.

Ph11. Mag. 4, 240; 1902

03. 8.1 IHE GOMPOSITION OF THE SURFAGE LAYERS OF AQUEOUS AMYL ALCOHOL

Benson, Miss

J. Phys, Chem. 7, 532; 1903

08.25.1 XANTHOGENIC ACID

Ragg, M.

Chem. Ztg. 32, 630: 1908

$2: 2547$

08.25 .2 XANTHOGENIC ACID

Ragg, M.

Chem. Ztg. 32,654 and $677 ; 1908$

$2: 2813$

10. 6.1 ELECTHOSTATIC SEPARATION OF MINERATS IN ORES Wentworth

Eng. Mining J. 90,$15 ; 1910$

10.25.1 XANTHOGENIC ACID AND DIXANTHOGEN

Ragg, M.

Chem. Ztg. 34, 82; 1910 
11.25 .1

rogers

Columbla Sch. Mines qtrly. 32, 298, 1911

13.25.1 XANTHOGENIC AOID AND THE KINETIGS OF ITS DECONPOSITION von Halban, $H$. and A. KIrsch

Z. physik. Chem. 82,$326 ; 1913$

$7: 2004$

14.25.1 WHE ELECTRIFICATION OF IIQUID-GAS SURFACES

MeTeggart, H.A.

Phil. Mag. 27, 297; 1914

$8: 1898$

Phil. Mag, 28, 36\%; 1914

$8: 3744$

15.25.1 WHY DO MINERAIS FLOAT

Ralston, $0 . C$.

Mining Sc1. Pross 111, 623; 1915

15.25.2 THE ELECTRICAI THEORY OF FLOTATION

Bains

MIning Sc1. Press 111, 824; 1915

111,$883 ; 1915$

16.3.1 AN EXPLANATION OF THE FLOTATION PROCESS

Taggart, A.F., and F.E. Beach

Irans.A.I.M.E. 55, 547; 1916

16.25.1 IHE ELECTROSTATICS OF FLOTATION

Mining Sc1. Press 112, 375; 1916

16.25.2 IHE CONSTITUTION OF LIQUIDS WITH SPECIAL REFERENCE TO SURFACE TENSION PHENOMENA

Langmua $r$, I.

Chem. Met. Eng. 15, 468; 1916

$10: 3008$

17.25.1. HIECTROSTATICS AND FLOTATION

Black

"Flotat1on" p. 200; Mining Sc1. Press 1917

18.25.1 XANTHIC ACIDS AND THE KINETICS OF THEIR DECONPOSITION von Halban, $H_{0}$ and W. Hecht

Z. Elektrochem. 24, $65 ; 1918$

J. Chem. Soc. 114, II-222;

13: 277

20.25.1 A CONTRIBUTION TO THE STUDY OF FLOTATION Sulman, H.I.

Trans. Inst. Mining and Met. (London) 29,44; 1920

20.25.2 MICROSCOPIC EXAMINATION OF THE ORE MINERAIS (BOOK)

Davy, and Farmham

NeGrav H111, 1920 
21.25.1 SURFACE ENERGY AND ADSORPTION IN FLOTATION Fahrenwald, A.W. Mining Se1. Press 123, 227; 1921

21.25.2 IHE FIOIATION PROGESS OF ORE DRESSING Ryskewits ch Chem. Ztg. 45, 478; 1921

22. 3.1 SURFACE TENSION AND ADSORPTION PHENOMENA IN FLOTATION Taggart, A.F., and A.M. Gaudin

Trans. A.I.M.E. preprint 1185M; Sept. 1922 Irans. A.I.M.E. 68,$479 ; 1923$

22.24.I THE CONCENTRATION OF MINERALS BY FLOTATION Edser, E. 4th Report Brit. Assn. Ad. Sci. p.263; 1922

22.25.1 THE FLECTRIFICATION OF LIQUID GAS SURFAGES

MeTaggart, H.A. Ph11. Mag. 44, 386; 1922

22.25.2. MOLECUIAR STRUCTURE AND THE PHYSICAL PROPERTIES OF LIQUIDS Edser, E. Report Brit. Assn. Ad. Sc1. p.40; 1922, 17:659

23.23.1 THE FLOTATION PROCESS

Berl, E. and H. Vierheller

z. ongew. Chem. 36,$161 ; 1983$

$17: 3855$

24. 3.1 SURHACE REACTIONS IN FIOTATION

Fahrenwald, A.W. Trans.A.I.M.E.No. 1283M; Jan 1924

$18: 1104$

24.12.1 THE FLOTATION PROCESS I. THE BEHAVIOR OF SILICIC ACID IN THE FLOTATION PROCESS

Berl, E. and W. P Pannmïller Kol101d Z, 34, 328; 1924

$18: 2863$

24.12.2 THE FLOTATION PROCESS II. THE BEHAVIOR OF OXIDES, CARBONATES AND SULFATES IN THE FLOTATION PROCESS Berl, E. and W. Prannmüller Kollold Z. 35, 34; 1924

$18: 3161$

24.12.3 THE FLOTATION PROCESS III. THE BEHAVIOR OF ALUMINIUM OXIDES IN THE FTOTATION PROCESS

Berl, E. and W. Pfannmuilier Kol101d Z. 35, 106; 1924

24.19.1 FLOTALION OF A UTAH SULFUR ORE Sherman, H.C. Utah Eng. Exp. Stn Bul1. 17; 1924 
24.25.1 FOAM

Bartsch, 0 .

Kolloldchem. Beihefte 20, 1; 1924

$19: 1076$

24.25.2 IHE THEORY OF FOAM FLOTATION

Bartsch, 0 .

Kolloldchem, Belhefte 20, 50; 1924

$19: 1077$

24.25.3 LHE ELECTRIFICATION OF LIQUID GAS SURFACES

Mctaggart, H.A.

Trans. Roz. Soc. Can. 18, III-129; 1924

25. 3.1 EFFECT OF CYANOGEN COMPOUNDS ON THE FLOATABILITY OF PURE SULFIDE MINERALS

Tucker, H.L., and K.E. Head

Trans. A.I.M.E. No. 1487B; Aug 1925

$19: 3450$

25. 6.1 DEVELOPMENT AND OPERATION OF A 50-GRAM FLOTATION MACHINE

Gates, J.F., and I.K. Jacobsen

ing. Mining J, Press 119, 771, 1925

$19: 2319$

25.19 .2

Gates, J.F., and I.K. Jacobsen

Utah ting. exp. Stn. Bul1. 16; 1925

26. 3.1 IHE EFFECT OF CYANOGEN COMPOUNDS ON THE FLOATABILITY OF PURE SULFIDE MINERALS

Tucker, E.I., J.F. Gates and H.E. Head

Mining Met. 7, 126; 1926

$20: 1376$

26. 5.1 SYNTHETIC TESTING FOR FLOTATION

McLachlan, C.G.

Bul1. Can. Inst. Mining and Met. 19, 987; 1926

Trans. " " " n " 29, 251; 1926

26.12.1 FOAMING ROWER AND SURFACE TENSION

Bartsch, 0 .

Kol101d Z. 38,$177 ; 1926$

$20: 3110$

27. 2.1 THE EFFECT OF CERTAIN CHEMIGALS ON THE ELOATABILITY

OF GALENA, SPHAIERIIE AND PYRITE

Buchanan, G.H. and L.J. Chrjstriann

American Cyanamid Co. T.P. 9; Nay 1927

27. 3.1 FLOTATION MECHANISM. A DISGUSSION OF THE FUNCTIONS OF FLOTATION REAGENTS

Gaudin, A.M.

A.I.M.E. - T.P. 4; 1927

$21: 3176$

27. 6.1 LHE "WHY" OF FIOTATION

Gaudin, A.M.

Eng. Mining J. 124, 1045; 1927

$22: 934$ 
27.11.1 DETERMINATION OF THE WETTABILITY OF A SOLID BY A IIQUID

Bartell, F.E. and H.J. Osterhof Ind. Eng. Chem. 19, 1277; 1927

22: 523

27.24.2 DETERMINATION OF THE NUMBER OF FREE ELECTRIC CHARGES ON AIR BUBBLES AND OIL DROPLETS DISPERSED IN WATER CONTAINING A SMALL AMOUNT OF CETYL SULFONIC ACID

McBain, J.W. and R.C.Wili1ams

Col101d Symposium Ann. 7, 104; Wiley, 1927

27.25.1 WORK OF ADHESION BETWEEN SOLID AND IIQUID PHASES

BarteII, F.E. and H.J. Osterhof

Z. physik. Chem. 130,715; 1927

$22: 531$

28. 3.1 FLOTATION MECHANISM. A DISCUSSION OF THE FUNCTIONS OF FLOTATION REAGENTS

Gaudin, A.M.

"Flotation Fractice" p 50, A.I.M.E. 1928

28. 3.2 THE ROLE OF SULFITES IN THE DIFFERENTIAI FLOTATION

PLANTS OF THE U.S. SRELTING AND MINING CO.

Pallanoh, R.A.

"Flotation Practice" p 78, A.I.M.E. 1928

28. 6.1 EARLY EFFORTS IN FLOTATION OF DRY MINERALS

Wood, H.E.

Eng. Mining J. 126, 571; 1928

28.9 .1

Mitrofanoff, S.I. and A.S. Mitrofanoff

Metal1 u. Erz 25, 644; 1928

28. 9.2 THE INFLUENCE OF ADSORPTION ON FLOTATION PROCESSES

Peetz, E.

Metal1 U. Erz 25, 494:1928

$23: 2913$

28.11.1 DEGREE OF WETTING OF SILICA BY CRUDE PETROIEUM OILS

Bartel1, H.E. and F.L.MIII0I

Ind. Eng. Chem 20,738; 1928

$22: 3520$

28.19.1 FLOTATION FUNDAMENTALS: FLOATABILITY OF PURE MINERALS AND THEIR MIXTURES

Gaudin, A.M., et al

$25: 1188$

Univ. Utoh Technical Papers, Including:

Pt. 1 I.P. 1 Gaudin, A.M., H. Glover, M.S. Hansen and C.W. Orr 1928

Pt. 2 T.P. 3 Gaudin, A.M. and P.M. Sorensen, 1928

Pt. 3 T.P. 5 Gaudin, A.M. and J.S. Mart1n, 1929

Pt. 4 T.P. 7 Gaudin, A.M., C.B. Haynos and E.C. Haas, 1930

Pt. 5 T.P. 9 Gaudin, A.M. and A.E. Anderson, 1930 
28.19.2 THE PREPARATION OF XANTHATES AND OTHER ORGANIC THIOCARBONATES Foster, I.S.

Utah Eng. Exp. Stn. T.P. 2; 1928

29. 8.1 A STUDY OF THE EFFECT OF CERTAIN CATIONS ON THE FLOTATION OF GALENA Taylor, N.W. and H.B. Bull

J. Phys. Chem 33, 641; 1929

29. 9.1 INVESTIGATIONS ON THE RELATION BETWEEN ADSORPTION, WETTING AND FLOTATION

Luyken, W., and E. Blerbraver.

Metail u. Erz 26, 197; 1929

$23: 4911$

29.10.1. IHE INFLUENCE OF HYDROGEN-ION CONCENTRATION ON RECOW ERY IN SIMPLE FLOTATION SYSTEFHS

Gaudin, A.M.

Mining Met. 9, 19; 1929

29.11.1 RELATION OF ADHESION TENSION TO "IIQUID ABSORPTION" Bartell, F.E. and $0 . H$. Greager

Ind. Eng. Chem 21, 1248; 1929

$24: 766$

29.15.1 WETTING AND ADSORPTION IN RELATION TO FLOTATION

Bierbrauer, $\mathrm{E}$.

Z. tech. Physik 10, 139; 1929

$23: 2913$

29.24.1 ELECTROSTATICS OF FLOTATION

Bu11, H.B.

Collo1d symposium 7, 115; 1929

$24: 4248$

29.25.1 INVESTIGATIONS ON THE THEORY OF FLOTATION

Luyken, W. and E. Blerbrauer

Mitt. Kaiser wilhelm Inst., Eisenforschung 11,

37; 1929

$23: 2912$

29.25.2 SOME SURFACE-CHEMICAL STUDIES CONTRIBUTING TO THE THEORY OF FLOTATION

Takakuwa, T. 25:5370

Proc. world Fing. Congr. Tokyo 1929. 35, 395; 1931

29.25 .3 MOSAIC CRYSTALS

Zwlcky, $\mathrm{H}^{\circ}$

Proc. Nat.AC. SC1. 15, 816; 1929

$24: 1005$

29.25.4 THE TREND OF FLOTATION

Weinig, A.J. and I.A. Palmer

Colorado School Mines qtriy. v24 \#4, 146 pp:i9286

29.25.5 THE ADSORPTION OF OIL ON MINERAL SURFACES WITH SPECIAL REFHRENCE TO FLOTATION

okada, J .

Proc. World Eng. Congr. Tokyo 1929 35, 367; 1931 
30. 2.1 CHEMISTRY AND THE FLOTATION PROCESS

Christmann, L.J.

American Cyanamid Co. T.P. 17; Nov 1930

30.3.1 GHEMIGAL REACTIONS IN FLOTATION

Taggart, A.F., T.C. Taylor and A.F. Knoll A.I.M.H._-T.P. 312; 1930

Trans.A.I.M.E., Miliing Methods (1930) 217

30. 3.2 A STUDY OF DIFFERENTIAI FLOTATION

Ince, C.R.

A.I.M.E.--I.P. 195; 1929

I'rans. A.I.H.E., MIlling Methods (1930) 261

30. 3.3 EXPERIMUNIS WITH FLOTATION REAGENTS

I'aggart, A.F., T.C. Taylor and C.R. Ince

A.I.M.E.--I.P, 204; 1929

Trans. A.I.M.E., Milling Methods (1930) 285

30. 3.4 FEDUCING AIND OXIDIZING AGENTS AND LIME CONSUMPTION IN

FLOTATION PULP

Ralston, 0.C., I. Klein, C.R. King, T.F. Mitehell,

O.E. Young, F.H. MLller and L.M. Barker

A.I.M.E.- - I.P. 224; 1929

Irans. A.I.M.E., Miling Methods (1930) 369

30. 3.5 COPPER SULFATE AS A FLOSAIION ACTIVATOR FOR SPHALERITE

Ralstion, $0 . C ., C . R$. K Ing and F.X. Tartaron

A.I.M.E.-T.P. 247; 1929

Trans. A.I.M.E., MIIIng Methods (1930) 389

30.3.6 ACTIVATION OF SPHALERITE FOR FLOTATION

Ralston, O.C. and W.C. Hunter

A.I.M.E.-T.P. 248; 1929

24: 42

Trans. A.I.M.E., MIIIIng Methods (1930) 401

30. 3.7 IHE EFFECII OF XANTHATES, COPPER SULFATE AND CYANIDES ON THE FLOTATION OF SPHALERITE

Gaudin, A.M.

Trans. A.I.M.E., Milling Methods (1930) 417

30. 3.8 THE EFFECT OF COPPER AND ZINC IN CYANIDATION

Leaver, E.S. and J.A. Woolf

Trans.A.I.M.E., MIIling Methods (1930) 536

30. 6. I THE PH VALUH IN FLOTATION AND MAXIMUM PROFIT

Hazen, H.L.

Eng. Mining J. 129,$458 ; 1930$

$24: 3864$

30.12.1 FLOTATION AND THE ELECTRICAL CHARGE ON PRECIPITATES

Talmu, $\mathrm{D}$. and $\mathrm{N}, \mathrm{M}$. Lubman

Kol1010 Z. 50,$163 ; 1930$

$24: 2355$ 
30.12.2 FUNDAMENTALS OF FLOTATION WITH XANTHATES NO. 1

Kellermann, $K$ and $E$. Bender

Kol101d Z. 52, 240; 1930

$24: 5682$

30.12.3 WETTING PHENOMENA ON SPHALERITE AND GAIENA

Beri, E. and B. Schmitt

Ko1101d Z. 52, 333; 1930

$24: 5682$

30.25 .1 HIOTATION REAGENTS

Holman, B.W.

Bu11. Inst. MIning and Met. 314; 1930 25:268

30.25.2 INVESTIGATIONS ON THE INFLUENCE OF THE IRON CONTENT OF ZINC BLENDES ON THEIR FLOATABILITY

Kraeber, L.

Mitt. Kalser Wilhelm Inst. 12, 343; 1930 25:2082

30.25.3, EXPERIMENTAL EVIDENGE OF THE MOSAIC STRUCTURE OF BISNUIH SINGLE CRYSTALS

Goetz, A.

Proc. Nat. Acad. Sc1, 16,99, $1930 \quad 24: 2928$

31. 1.1 COMPOSITION OF COPPTR XANTHATE

Matuszak, M.P.

J. Am. Chem. Soc. 53, 4451; 1931

26: 433

31.3 .1

Fahrenwald, A.W.

A.I.M.E.- -T.P. 416; 1931

31. 9.1 INFLUHNCH OF TEMPERATURE UPON FLOTATION

Huber-Panu, I. Metall u. Erz 28, 545; 1931

$26: 1221$

31. 9.2 XANTHATES AS COLLECTORS

sledier, $P$.

Metali u. Erz 28, 425, 1931

$25: 5882$

31.16.2 PHYSICAL CHEMISTRY OF FLOTATION 3. INFLUENCE OF

FLOTATION REAGENTS ON SELECTIVE WETTING AS CHARACTERISTIC OF COLLECTING POWER

Lipetz, M.E, and M.M. RImskaya

Tzvetnule Metal 1931, 990

$26: 1882$

31.22.1 DIFFERFNTIAI WETTING EFFECTS IN FLOTATION

Barsky, G. and S.A.Falconer

Trans. Electrochem. Soc, proprint $60 ; 1931$

$25: 4824$

31.22.2 ON THE PHYSICAL CHEMISTRY OF FLOTATION

Freundlich, $\mathrm{H}$.

Trens. Electrochem. soc. preprint 60 ; 1931

$25: 4824$ 
31.22.3 FIOGCULATION AND FROTH QUALITY IN FLOTATION

Ralston, O.C. and I.M. Barker

Trans - Electrochem. Soc.preprint $60 ; 1931$

$31.22 .3 \mathrm{~A}$

Buchanan, G.H.

Trans. Electrochem. Soc. preprint 60,$93 ; 1931$

31.22 .4 SOIUBILITY, PEPTIZATION, WETTING AND FLOTATION

Fahrenwald, A.W.

Trans. Electrochem. Soc. preprint 60,$311 ; 1931$.

31.23.1 ADSORPTION INTENSITY AND ITS IMPORTANCE IN TECHNICAL PROCESSES

Iraube, I.

Z. engew. Chem, 44; 1931

$25: 2616$

32. 1.1 SURFACH RELATIONS OF POTASSIUM ETHYL XANTHATE AND PINE OII NO. I

De Witt, C.C. and E.E. Roper

J.Am. Chem. Soc. 54, 444, 1932

$26: 1840$

32. 6.2 DFPRESSION BY CYANIDE IN FLOTATION CIRCUITS

Brighton, T.B., G. Burgener and J. Gross

Eng. Mining J. 133,$276 ; 1932$

$26: 3758$

32.6.5 PERFECTION AND USE OF THE 50-GRAM FTOTATION CELI Hansen, H.S.

Eng. Mining J. 133, 28, 1932

32. 8.1 MTNERAL FLOTATION

Faggart, A.F.

J. Phys. Chem. 36, $130 ; 1932$

$26: 1221$

32. 8.3 ADHESION TENSION

Bartel $1, E$. and $\mathrm{C} . \mathrm{E}$. Whitney

J. Phys.. Chem. 36, 3115; 1932

$27: 1255$

32.10 .1 BUBBLE ATTACHMENT IN FLOTATION

shepard, 0.C.

Nining Net. 13,$282 ; 1932$

32.11.1 PREFERENTIAI WETTING OF SOLIDS BY IIQUIDS

David, N.S. and H.A. Curtis

Ind. Eng. Chem 24, 1137; 1932

$26: 5816$

32.11.2 DISPLACEMENT OF CRUDE OIL AND BENZENE FROM SILICA BY AQUEOUS SOLULIONS

Bartell, F.E. and F.I. M11ler

Ind. Eng. Chem. 24, 335; 1932

$26: 3366$ 
32.12.1 THEORY OF FLOTATION

Ostwald, Wo.

K0110id Z. 58,$179 ; 1932$

$26: 2946$

32.12.2 THEOPY OF FLOTATION

Siedler, P., A. Moeller and T. Reddehase

Kollo1d Z. 60,$318 ; 1932$

$26: 5884$

32.12 .3 HYDROLYSIS AND DISSOCIATION OF XANTHATES

Schaum, K., P. Siedler and E. Wagnero

Kol101d Z. 58,$341 ; 1932$

$26: 3430$

32.22. 1 THE PHYSICAL CHHMISTRY OF FIOTATION

Wark, I.W.

$26: 1550$

Trans. Electrochem. Soc. preprint 61,$427 ; 1932$

32.25.1 ELECTROSTATIC EXPLANATION OF FLOTATION

Kamienski, $B$.

Nature, 129, 59; 1932

$26: 1550$

32.25.2 ELECTROSTATIC POTENTIALS AT PHASE BOUNDARY ELECTROLYTEUNATTACKABLE ELECTRODE AND THE PHYSICAL CHEMISTRY OF FLOTATION

Kamiens $k 1, B$.

Z. physik. Chem. A158, 441, 1932, 26:2660

32.25.3 MEGHANISM OF THE FLOTATION PROCESS

Talmud, D.I.

Physik Z. Sowjetunion 1, 603; 1932

$26: 5519$

32.25.4 THE EFFECT OF ACTIVATED CHARCOALS ON THE FLOTATION OF ORES

Braunstein, $\mathrm{k}$.

Kohle u. Erz 29, 189; 1932

$27: 2117$

32.25 .5 FLOTATION (BOOK)

Gaudin, A.M. MCGraw HIII, 1932

32.25.6 ELECTROCAPILLARY TESTS IN CONNECTION WIIH THE PROBLEM OF FLOTATION

Sven-NIIs son, $I$.

Iva 3,50; 1932

$27: 2116$

33. 1.1 APPLICATION OF THE GIBB'S ADSORPTION THEOREM TO SOIID-IIQUID INTERFACES

Bartell, F.E., F.I. Miller and E.G. Almy

J. Am. Chem. Soc. 55, 466; 1933

$27: 1798$

33. 5.1 SOLUBLE METAI XANTHATES AND THEIR EFFECT ON DIFFERENTIAI FLOTATION

Warren, S.P.

Bul1. Can. Inst. Mining Met. 251, 186; 1933 
33. 8.1 PHYSICAL GHEMISTRY OF FLOTATION 1. SIGNIFICANCE OF THE CONTACI ANGLE Wark, I.W.

J. Phys. Chem. 37, 623; 1933 $27: 4194$

33. 8.2 FHYSICAI CHEMISTRY OF FLOTATION 2. NATURE OF ADSORPTION OF SOLUBLE COLIECTORS

Cox, A.B. and I.W. Wark

J. Phys. Chem. 37, 797; 1933

$27: 1596$

33. 8.3 PHYSICAL CHEMISTRY OF FLOTATION 3. THE RETATION

BETWEEN CONTACT ANGLE AND CONSTITUTION OF COLLECTOR Wark, E.E. and I.W. Wark

J. Phys. Chem. 37, 805; 1933

$27: 4194$

33. 8.4 PHYSICAI CHEMISTRY OF FLOTATION 4. CRITICISM OF OSTWALD'S THEORY

Wark, $1 . W$. and A.B. Cox

J. Phys. Chem. 37, 815; 1933

$27: 4195$

33. 8.5 SURFACE REACTIONS OF SOME SULFUR BEARING ORGANIC COMPOUNDS WITH SULFIDES

Gaudin, A.M. and W.D. Wilkins on

J. Phys. Chem. 37,$833 ; 1933 \quad 28: 79$

33. 8.6 ADHESION TENSION. PRESSURE OF DISPLACEMENT METHOD

Bartell, H.E. and H.J. Osterhof

J. Phys. Chem. 37,$543 ; 1933$

$27: 3868$

33.12.1 WETTING HXPERIMENIS ON HYDROPHILIC AND HYDROPHOBIC POWDERS IN SYSIEMS OF TWO IMMISCIBLE LIQUIDS. 2. ADSORPTION AND WETTING OF GALENA AND SPHALERITE

BerI, E., B. Schmitt and H. Schulz

KoIlold Z. 63,$327 ; 1933$

$27: 4149$

33.12.2 THE DEPENDENCE OF WETTING OF SOLIDS ON THE TIME OF CONTACT

Pockels, Agnes

Kollo1d Z. 62, 1, 1933

$27: 1798$

33.12.3 MICROSCOPY OF FLOTATION PHENOMENA IN REFLECTED LIGHT King, N.

Kollo1d Z. 62,$343 ; 1933$

$27: 2117$

33.12.4 IHE MECHANISM OF THE FLOTATION PROCESS

Talmud, D.

Ko1101d Z. 62,$375 ; 1933$

$27: 2116$

33.13 .1

Dean, R.S., J. Gross et al

U.S. Bur. Mines 544B; 1933 
33.25.1 KATE OF WETTING AND FLOTATION

Freundlich, $\mathrm{H}, 0,0$. Ensin and $\mathrm{G}$. IIndau

Ko110id Beiherte 37, 281; 1933

$27: 3376$

33.25.2 INFLUENCE OF FOREIGN SUBSTANCES ON THE UPTAKE OF

LIQUIDS BY NON-SWELIING POWDERS

Freundilch, H., O. EnsIIn and $G$. IIndar

K01101d Beihefte 37, 242; 1933

$27: 3376$

33.25.3 THE REACTION OF CERTAIN SULFUR-BEARING COLIECTORS

HITH CERUSSITE AND GAIHNA

Johnson, R.A.

Thesis, Montana School of Mines; 1933

33.25.5 THE WATER-AVIDITY OF INSOLUBLT SUBSTANCES, AND THE REMARKABLE FORCES OF ATTRACTION EXISTING AT THE INIERFACE OF NON-MISCIBLE IIQUIDS

Derave, H.

Compt. rend. 197, 105: 1933

$27: 4983$

33.25.6 IHE CHEMICAI BASIS OF FLOTATION

Wark, I.W.

28:1307

Proc. Australasian Inst. Mining Met. 90,$83 ; 1933$

34. 1.1 QUANTITATIVE CORRELATION OF INTERFACIAI FREE SURFACE ENERGIES

Barte11, F.E., and L.S. Barte11

J.Am. Chem. SOC. 56, 2205, 1934,29:973

34. 3.1 OXYGEN-FREE FLOTATION, 1. FLOTATION OF GALENA IN THE ABSENCE OF OXYGEN

Ravitz, S.F. and R.R. Porter

A.I.M.E.- - T.P. 513: 1933

$28: 1308$

34. 3.2 PRINCIPLES OF FLOTATION. 1. AN EXPERIMENTAL SIUDY OF THE EFFECT OF XANTHATES ON CONTACT ANGLES AT MINERAL SURFACES

Wark, I.W. and A.B. Cox

A.I.M.E.-.I.P. 461; 1932

Trans. A.I.M.E. 112, 189; 1934

$26: 1881$

34. 3.3 PRINCIPLES OF FLOTATION, 2. AN EXPERIMENTAL SIUDY OF THE INFLUENGE OF CYANIDE, ALKALIS AND COPPER

SULFALE ON THE EFEECT OF POTASSIUN ETHYL XANTHATE

AT MINERAL SURFACES

Wark, I.W. and A.B. Cox

A.I.M.E.--I.P. 495; 1933

Trans. A.I.M.E. 112, 245; 1934

$27: 1596$ 
34. 3.4 PRINCIPLES OF FLOTATION, 3. AN EXPERIMENTAL STUDY OF THE INFIUENCE OF CYANIDE, AIKAIIS AND COPPER SULFATE ON THE EFFECT OF SULFUR-BEARING COLLECIORS AT MINERAL SURFAOES

Wark, I.W. and A.B. Cox

$A . I . M . E .--T . P .574 ; 1934$

Irans. A.I.M.E. 112, 267: 1934

34. 3.5A RHACTIONS OF XANTHATHS WITH SULFIDE MINERAIS

Gardin, A.M., F. DeweJ, W.E. Duncan, R.A. Johnson and $0 . F$. Tange $1 \mathrm{~J} r$.

Trans. A.I.M.E. I12, 319, 1934

34. 3.6 IHE CASE FOR THE CHEMICAL IHEORY OF FLOTATION

Taggart, A.F., G.R.M. deI Gludice and O.A. ZiehI

Irans. A.I.M.E. 112, 348, 1934

$29: 7886$

34. 3.7 THE ACTION OF ATKALI XANTHATES ON GALENA

Taylor, $1 . C$. and A.F.KnOII

A.I.M.E.-Contribution \#26; 1933

Trans. A.I.M.E. 112, 382; 1934

34. 3.9 RETATIVE FLOATABILITY OF SIIICATE MINEHALS

Patek, J.M.

A.I.M.E. $-=$ I.P. 564, 1934

Trans. A.I.M. H. 112, 486; 1934

$28: 6664$

34. 6.2 SOAP FLOTATION-ACTION OF DEPRESSING GEIS

Patek, J.AI.

Eng. MLIng J, 135, 125; 1934

$28: 2649$

34. 6.3 FUNDAMENTAIS OF FLOTATION IN THE LIGHT OF MODERN RSSEARCH

del Gludice, G.R.M.

Eng. Mining J. 135, 152, 1934

$28: 3341$

135,$213 ; 1934$

$28: 3695$

135,$257 ; 1934$

135,$350 ; 1934$

$28: 5789$

34. 6.4 COLIOIDAL DEPRESSORS IN SOAP FLOTATION

Patek, J.M.

Eng. Hining J. 135,$558 ; 1934$

$29: 1037$

34. 8.1 ADSORPIION OF COPPER SULFATE BY SPHALERITE AND IHS REILATON TO FLOTATION

Revitz, s.F. and W.A.Wa11

J. Phys. Chem. 38, 13; 1934

$28: 2591$

34. 8.2 ADHESION TENSION OF LIQUIDS AGAINST STRONGLY HYDROPHIIIC SOIIDS. A SERTES OF IIQUIDS AGAINST BARITE

Barte11, F.E. and H.Y. Jennings

J. Phys. Chem. 38, 495; 1934

$28: 4288$ 
34. 8.3. AITERATION OF THE SURFACE PROPERTIES OF STIBNITE AS RHVEALED BY ADHESION-TENSION STUDIES

Bartell, $H^{\prime} . E$. and C.W. Walton

J. Phys. Chem. 38, 503; 1934

$28: 3960$

34. 9.1 EFFECT OF METALLIC SALTS UPON FLOTATION OF OXIDIC MINERALS

Kraeber, L. and A. BoppeI

Metall u. Erz 31, 412; 1934

29: 85

34.12.1 HFFECT OF CONTACT TIME BETWEEN MINERAL AND AIR-BUBBLE ON FLOTATION

Sven-N118son, 1 .

KoI101d Z. 69, 230; 1934

$29: 1367$

34.12 .2 CONTRIBUIION HO THE IHEORY OF FLOTATION

sledier, $\mathrm{P}$.

Ko1101d Z, 68,$89 ; 1934$

$28: 6403$

34.12.3 IHE THHORY OF FIOTATION III.

Ostwald, Wo.

KO1101d Z, 68,$103 ; 1934$

$28: 6403$

34.16.1 MECHANISM OF FLOTATION WITH WATER-INSOIUBLE REAGHNTS

1. FUNCTION OF THE NON-POLAR PHASE IN THE PROCESS OF ADSORPTION OF A REAGENT ON THE SUSPENSION

PARTICLES

Volkova, Z.V. and N.N. Serb-Serbina

Mineral sulre 9, \#10,19; 1934

$29: 1899$

34.16.2 APPLICAIION OF IHE SAIURATION METHOD FOR THE INVESTIGATION OF THE MINERAL DISPERSOIDS. A STUDY OF THE COMPARATIVE WETTING OF CORUNDUM POWDERS

Volkova, Z.V.

Acta Phys Icochim. U.R.S.S. I, 247; 1934 29:7744

34.25.1 ACTIVATION OF SPHALERITE

Beck, A.B.

Chem. and Ind. 1934, 104

$29: 2122$

34.25.2 ACTION OF DILUTE SILVER NITRATE ON MINERAL SULFIDES

KamenetzI, S.A.

Z. anorg. 211gem. Chem, 219, 335; 1934, 29: 24

34.25.4 IHE NAYURE OF ADSORPIION FORCES

de Boer, J.H. and J.F.H. Custers

Z. phys1k. Ghem. 25B, 225; 1934

$28: 4646$

34.25.5 EFFECT OF $\mathrm{PH}$ AND VARIOUS GHEMICALS ON THE FLOTATION OF PYRRHOTITE

Yamada, G. and M. Muraoka

Sulyokwa1-Sh1 8, 435; 1934

$28: 4687$ 
35. 1.1 SURFACE RELATIONS OF THE XANTHATES

De Witt, C.C., R.F. Makens and A.W. Helz

J. Am. Chem. Soc. 57, 796; 1935

$29: 4298$

35. 3.1 NEV YLOIATION REAGENTS

Dean, A.S. and A.B. Hersberger

A.I.M.E. $--T . P .605 ; 1935$

$29: 2121$

35. 6.1 FATTY ACID AND SOAP FLOTATION APPLIED TO OXIDIZED COPPER ORE

Rey, H.

ting. Hining J, 136, 221, 1935

35. 8.1 PHYSICAI CHEMISTRY OF FLOTATION 5. FLOTATION OF GRAPHITE AND SULFUR BY XANTHATE COLLECTORS, AND ITS BEARING ON THE THEORY OF ADSORPTION Wark, I.W. and A.B. Cox

J. Phys. Chem. 39, 551; 1935

$29: 6974$

35. 8.2 PHYSICAL CHEMISTRY OF FLOTATION 6. ADSORPTION OF AMINES BY SULFIDE MINERAIS

Wark, I.W. and E.E. Wark

J. Phys. Chem, 39, 1021, 1935

30: 59

35. 8.3 THE WETTING GHARACTERISTICS OF GALHNA

Barte11, F.E. and G.B. Hatch

J. Phys. Chem. 39, 11: 1935

$29: 2420$

35. 9.1 ACTION OF XANTHATES ON GALENA

Wilkins on, W.D.

Metal1 u. Erz 32, 157; 1935

$29: 5789$

35.12.1 MECHANISM OF FLOTATION. ADSORPTION ON TALC AND ITS FIOTATION.

Volkova, Z.V., N.N. Serb-Serbina and A.V. Zaporozhetz K01101d Z. 71, 230; 1935

$29: 7703$

35.12.2 MECHANISM OF FLOTATION. ROLE OF HIGHLY DISPERSED POWDER

Volkova, Z.V. and Z.V. Zaporozhetz

KOIloId Z. 72, 82; 1935

$29: 7703$

35.12.3 MECHANISM OF FLOTATION 4. ORIENTED COAGULATION IN NON-POLAR AND AQUEOUS MEDIA

Volkova, Z.V.

Kollo1d Z, 72, 229; 1935

$29: 7703$

35.12.4 EXPERIMENTAL INVESTIGATION OF LAMINAR SYSTEMS. 1. UNIMOLECULAR AND MULTIMOLECULAR SULFIDE AND HYDROXIDE FILMS AT INTERFAGES

Mokrushin, S.G.

Kol101d Z, 70, 48; 1935

$29: 2420$ 
35.16.1 ADSORPTION OF ORGANIC SUBSTANCES ON THE SURFACE OF CRYSTALS AND THE EFFECT OF ELECTROLYTES ON THE EXTENT OF ADSORPTION HeI'd, N.A.

Mekhanobr (in English) 161; 1935 $30: 2451$

35.16.2 DEPRESSING ACTION OF HYPOSULFITES Trusov, $\mathrm{P} \cdot \mathrm{D}$.

Mekhanobr, Russ1a 1, 164; 1935 $30: 3373$

35.17.1 CONTRIBUTION TO THE THEORY OF FLOTATION Rey, M.

Congr. Intern. mines motal geol. appl. 7e session, Par1s 1935, Mines 1, $270 \quad 30: 7073$

35.18.1 LAMINAR SYSTEMS 8. EFFECT OF ELECTROLYTES ON THE WETTABIIITY OF FILMS OF METALLIC SULFIDES Mokrushin, S.G. and N. Demenev. J. Phys. Chem.(U.S.S.R.) 6, 1269; $1935 \quad 30: 7415$

35.18.2 LAMINAR SYSTEMS 5. ADSORPTION OF ELECTROLYTES BY COPPER SULFIDE FILMS

Mokrashin, S.G. and G.F. V111esova

J. Phys. Chem. (U.S.S.R.) 6,$640 ; 1935 \quad 29: 7748$

35.18.3 IAMINAR SYSTEMS 7. WETTING PHENOMENA ON SURFACE FILMS OF METAIIIC SULFIDES

Mokrushin, S.G. and N. Demenev

J. Phys. Chem. (U.S.S.R.) 6, 1066; 1935 31: 18

35.25.1 ACTION OF FLOTATION REAGENTS ON THE CHARGE IN MINERAL SUSPENSIONS

TIkhonov, M.K.

$29: 7886$

Bul1. acad. Sc1. U.R.S.S. 1935; 253 (In English)

35.25.3 THE THEORY OF FLOTATION

ostwald, Wo.

Z. phys1k. Chem.A173, 393; 1935

$29: 7703$

35.25.4 THE THEORY OF FLOTATION

Wark, I.W.

Z. physik. Chem. AI73, 265; 1935

$29: 7703$

36. 1.1 WETTING CHARACTERISTICS OF SOIIDS OF LOW SURFACE TENSION, SUCH AS TALC, WAXES AND RESINS.

Barte11, F.E. and Zuidema

J. Am. Chem. Soc. 58,$1449 ; 1936$

$30: 6620$

36. 3.1 PRINCIPLES OF FLOTATION 4. AN EXPERIMENTAL STUDY OF THE INFLUENCE OF SODIUM SULFIDE, ALKALIS AND COPPER SULFATE ON THE EFFECT OF XANTHATES AT MINERAL SURFACES

Wark, I.W. and A.B. Cox

A.I.M.E.--T.P. 659; 1936

30: 997 
36. 3.2 PRINCIPLES OF FLOTATION 5. CONCEPTION OF ADSORPTION APPLIED TO FLOTATION REAGENTS

Wark, I.W. and A.B. Cox

A.I.M.E.- $-T . P \cdot 732, B 59 ; 1936$

36. 6.1 THE BUBBLE MACHINE FOR FLOTATION TESTING

del Giudice, G.R.M.

Eng. Mining J. 137, 291; 1936

36. 6.2 THE BUBBLE MACHINE FOR FLOTATION TESTING

$\mathrm{Cox}, \mathrm{A} . \mathrm{B}$. Eng. Mining J. 137, 641; 1936

36. 8.1 PHYSICAL CHEMISTRY OF FLOTATION 7. TRIMETHYLCETYL AMMONIUM BRORIDE AS A FLOTATION REAGENT Wark, I.W. J. Phys. Chem. 40,661; 1936

36. 8.2 PHYSICAL CHEMISTRY OF FLOTATION 8. THE PROCESS OF ACTIVATION

Wark, E.E. and I.W. Wark

J. Phys. Chem. 40, 799; 1936

$30: 8106$

36. 8.3 AOTION OF POTASSIUM ETHYL XANTHATE ON CHALCOGITE Gaudin, A.M. and Schumann

J. Phys. Chem. 40, 257; 1936

$30: 4443$

36. 9.1 MARGINAL ANGLE AND FLOTATION ABILITY

Valentiner, $s$.

Netall u. Erz 33, 221; 1936

$30: 4443$

36.16.1 FLOTATION AND SUSPENSION STABIIITY OF ZINC BLENDE

Mitrofanov, S.I and Arashkevich

Gorno-0bogatitel Zhur. 4, 9; 1936

31: 636

36.16.2 THE FLOTATION OF SULFIDE AND OXIDIZED MINERALS

Shvedor, D.A.

Gorno-obogatitel Zhur. 6, 24, 1936

$31: 2133$

36.16.3 THE USE OF SODIUN SULFIDE AT ZYRYANOVSK ORE-DRESSING PLANT

Sladkov,

Tsvetnye Metal 1, 66, 1936

$31: 5303$

36.16.4 A QUANTITATIVE STUDY OF FLOCCULATION AS A METHOD FOR CHARACTERIZING THE REAGTION OF THE MINERAL WITH THE REAGENT IN THE FLOTATION PROCESS

Shneers on, V.B.

Tsvetnye Metal. 10, 33; 1936

$31: 2133$

36.16.5 DEPRESSING AND ACTIVATING ACTION OF SODIUM SULFIDE DURING FLOTATION

Belash, Kedkle Motal $5, \# 6,27 ; 1936$ 
36.25.1 WHE LFFECT OF $\mathrm{PH}$ AND THE ADDITION OF VARIOUS CHEMICALS ON THE FLOTATION OF ARSENOPYRITE

Yamada, G. and Jyo

Sulyokwa1-sh1 9, 83; 1936

$31: 1329$

36.25.2 THE EFFECT OF $\mathrm{pH}$ AND THE ADDITION OF VARIOUS CHEMICALS ON THE FLOTATION OF ENARGITE

Yamada, G. and Kolzums

Su1yokwal-Sh1 9, 89; 1936

$31: 1329$

36.25.3 THE EFFECT OF XANTHATES ON THE WETTABILITY OF SULFUR Demener, $\mathrm{N}$.

Collo1d J.(U.S.S.R.) 2, 665, 1936

$31: 2064$

36.25.5 THE RELATION BETWEEN PEPTIZATION OF A PRECIPITATE AND ITS ELECTROKINETIC POTENTIAL

Chaudbury, and Sen-Gupta

J. Indian Chem. Soc. 13,670; 1936

$31: 3769$

36.25.6 THE EFFECT OF $\mathrm{PH}$ AND THE ADDITION OF VARIOUS CHEMICALS ON THE FLOTATION OF CHALCOPYRITE

Yamada, G. and WaksaugI and Naganuma

Sulyolkwal-Shi 8,$943 ; 1936$

$30: 3755$

36.25.7 THE EFFECT OF PH AND THE ADDITION OF VARIOUS CHEMICALS ON THE FLOTATION OF SPHALERITE

Yamada, $G$. and Naganuma

Suigokwai-Shi 9, 47; 1936

$30: 6679$

37. 4.1 REVIEW OF REGENT FLOTATION PATENTS

Bassett, I.

Can. Mining J. 58, 185; 1937

58,$255 ; 1937$

$58 ; 304 ; 1937$

58,$356 ; 1937$

37. 5.1 HROTH FLOTATION AND AGGIOMERATE TABLING OF NONMETALIIC MINERRIS

Ralston, 0.C.

Bul1. Can. Inst. Mining Met. 307,$691 ; 1937$

37. 6.1 'HE PROBLEN OF MEASURING SETTIING RATES OF MINERAL

SUSPENSIONS WITH DATA ON THE FLOTATION OF QUARTZ

Fahrenwald, A.W. and J. Newt on

Eng. Mining J. 138, 23; 1937

37. 8.1 PHYSICAL CHENISTRY OF FLOTATION 9. ADSORPTION OF

XANTHATES BY ACTIVATED GARBON AND GRAPHITE AND

ITS RELATION TO THE THEORY OF FLOTATION

Wark, I.W. and A.B. Cox

J. Phys. Chem. 41, 673; 1937 
37.12.1 DISPERSH HYSTERETIC DIFFERENTIAL WETTING. THE KINETICS OF WASHING OFF THE ADSORPTION LAYERS AS A METHOD OF SIUDYING CHEMICAI REACTIONS IN THE SURFACE FILM KIyrachko,

K01101d Z, 78, 171, 1937

$31: 4560$

37.13 .1 USE OF WETTING AGENTS IN FLOTATION

Dean, R.S., J.B. Clemmer and S.R.B. Cooke U.S. Bur. Mines R.I. $3333 ; 1937$

37.13.2 ORE DRESSING TESTS AND THEIR SIGNIFICANGE

Dletrich, W.F., A.I. Engel and P. Grggenheim U.S. Bur. Mines R.I. 3328: 1937

37.16.1 ADSORPTION OF FLOTATION REAGEITS ON MINERAL SURFACES Rimskaya, Gorro-obogatitel Zhur. 2, 27; 1937

37.16.2 ISOIHERMS OF WETTING AS APTLIED TO FLOTATION Mantser, Gorno-obogatite1, Zhur. 2, 32; 1937 $31: 5303$

37.16 .3 STUDY OF GOLD FLOTATION BY THE "ZERO" METHOD Mitrofanov, S.I.

Gorno-Obogatite1 zhur. 3, 22, 1937

37.16.4 ISOTHERMS OF WETTING OF ZINC SULFIDE AND LEAD SULFIDE GENERAI HYSTERESIS OF WETTING

Mantser,

Gormo-Obogatitel zhur. 3, 28; 1937

$31: 5728$

37.16.5 ELECTRIC POIHNIIALS AT THE INTERFACE OF PHASES IN THE FLOTATION PROCESS

Kamlensk1, and Benis

Rocznik1 Chem. 17, 89; 1937

$31: 4560$

37.16.6 INFLUENCE OF OXIDATION ON THE FLOTATION OF SULFIDE MINERALS

Shvedor, D.A. and Shorsher

Gorno-obogatitel zhur. 9-10, 24; 1937

$32: 1218$

37.16.7 HLOTATION OF GOLD BY THE ZERO METHOD

Mitrofanov, S.I. Gorno-obogatitel zhur. 9-10, 31; 1937

37.16.8 WETTING OF MINERAI SURFACES AND THE PHENOMENON OF FLOTATION OF MINERAL SURFACES

Iubman, N.N.

Gomo-obogatite1 Zhur. 9-10, 39; 1937

$32: 1217$ 
37.25.1 ADSORPIION FORCES AND THEIR ELECTRICAL NATURE III. NATURE OF THE FORCES OF WETTING

IIIIin, Leontiew and Bragin

Ph11. Mag. 23, 294; 1937

37.25.2 THE EFFECT OF PH AND THE ADDITION OF VARIOUS CHEMI-

CALS ON THE FLOTATION OF SULFIDE MINERALS

9. MARMATITE

Yamade, $G$. and Naganuma

Sulyolkwa1-Sh1, 9, 197; 1937

37.25 .3 THE FLOTATION OF STIBNITE

Yomada, G. and Yokoyama

sulyokwal-Sh1 9,$245 ; 1937$

38. 3.1 PRINCIPLES OF FLOTATION 6. INFLUENCE OF TEMPERATURE

ON THE EFFECT OF COPPER SULFATE, ALKAIIS AND

SODIUM CYANIDE ON THE ADSORPTION OF XANTHATES AT MINERAI SURFACES

Wark, I.W. and A.B. Cox

A.I.H.E.--T.P. 876; Jan. 1938

38. 3.2 OIL-AIR SEPARATIONS OF NON-SULFIDE AND NON-METALIIC MINTRAIS

Taggart, A.F.

A.I.M.E.- $-T \cdot P \cdot 838 ; 1938$

38. 4.1 A REVIEW OF RECENT FLOTATION PATENTS

Bassett, I.

Can. Mining J. (In press) 


\section{PART 2.}

EXPERTMENTAI

The Solubility of Iead Ethyl Xanthate

and

The Flotation of Lead Sulfide 


\section{ACKNOWLEDGHENT}

The author appreclates the guldance of Dr. Wm. Ure, under whose general direction this research was carrled out; and the help of Rex F. Pearce; B.A.SC., who assisted in preparing materials used in the work. 


\section{THE SURFACE CHEMISTRY OF FLOTATION \\ - PART 2. BXXPERIMHNTAI \\ The Solubility of Iead Ethyl Xanthate \\ and \\ The Flotation of Lead Sulfide}

\section{CONIENTS}

INTRODUGTION TO EXPERIMENYAL WORK

Page

PREPARATION OF MAIERIAIS, ETC.

SOLUBILITY OF LEAD ETHYL XANTHATE 3

Gravimetric Procedure 3

Colorimetrie Procedure $\quad 4$

SOLUBILITY OF CUPROUS ETHYL XANTHATE 12

METHODS FOR MEASURING FLOATABILITY 14

FLOTATION WITHOUT REAGENTS 16

FLOTATION WITH TERPINEOL ALONE (Inherent Floatablity) 27

FLOTATION OF XANTHATE-TREATED GAIENA WITH TERPINEOL 30

A FURTHER EFFEGT OF $\mathrm{pH} \quad 35$

SUMYARY 37

ILLUSTRATIONS

Fig. Facing Page

1. Lead ion Concentration in Solutions of Various $\mathrm{pH}$ Containing solld Iead Ethyl Xanthate

2. Flotation Cell

3. Elutriator 
11.

Fig.

Facing Page

4. Flotation without Reagents

5. Recovery of Xanthate-treated Galena vs. pH

6. Change of $\mathrm{pH}$ with rime. Flotation of Xanthate-treated Galena. Alkallne Range

7. Change of $\mathrm{pH}$ with Time. Flotation of Xanthate-treated Galena. Acid Range 
THE SURFACE CHEMISTRY OF FLOTATION

PART II

INIKODUCTION TO EXPERIMENTAL WORK

Prevlous Investigators have demonstrated that flotation of a solld is accomplishod by malntaining or producing a hydrophobic coating on its surface, and that non-flotation results when the coating is hydrophilic. The mechanism by Which the surface of a solld mineral becomes more hyarophobie after contact with a solution of a collector has not been sat. 1sfactorlis explained. It is thought to be either chemical metathes is between entities derived from the mineral and the soluble collector; or adsorption of the collector, in whole or part, on the mineral surface. It has been show that xanthate collectors are abstracted from solution by minerals if the basic constituent of the mineral forms a xanthate of low solubility, and are not abstracted if the zanthate has an appreclable solubility. It has also been shown that achesion between an air-bubble and a renthate-treated mineral surface is possible only below a critical pH value; more or less specifle for a particular xanthate and mineral.

It is the purpose of the present livestigation to determine the effect of $\mathrm{pH}$ on the solubility of certain base metal xanthates, and on the floatability of the corresponding ranthate-treated minerals, and to determine whether any correlation exists between this solubility and the floatability of 
the mineral.

For the Investigation, galeng and potassium ethyl xanthate were selected as a typlcel mineral and collector, respectively.

\section{PREPARATION OF MATERIALS, ETC.}

The preparation and purification of the reagents used are described by H.F. Pearee?

Mneral specimens used in flotation tests are described be10w:

Galona \#1 Massive specimen of Sullivar galena obtained from Geology Dept., Unlversity of B.C.

Galene H2 Large specimen, visibly altered on the surlace, and composed of $1 / 4^{\prime \prime}$ and larger cubes: obtalned from Geology Dept, University of B.C.

Galena \#3 Fine crystaline

Galena \#4 Nodium crystals, containing sphalerite and quartz.

Galene H5 $^{5}$ Slver-Ieqd ore from St. Eugene Extension Mine. Massive, brittle, highly-lustrous speci. men with no visible impurities. Obtalned from B.C. Chamber of Mines, Vancouver.

AII pH determinations were made with a Beckman glasselectrode pi meter.

1. The Surface Chemlstry of Flotation. The Solublilty of tinc Ethyl Xanthate, H.F.Pearce, B.A.Sc. lhesis, Univers $1 t y$ of British Columbia, 1938 


\section{SOLUBILITY OF LEAD ETHYL XANTHATE}

\section{- Gravimetric Procedure}

\section{Procedure}

Equivalent quantities of lead nitrate $(0.2948 \mathrm{gms}$.$) and$ potassium ethyl ranthate $(0.2852) \mathrm{gms}$.$) to form 0.4 \mathrm{gms}$. of lead ethyl xanthate were dissolved in separate 500 ce. portions of water. The solutions were mixed, and the mixture allowed to stand overnight, while the preclpitate became completely flocculated.

Ihls suspension of lead ethyl xanthate was flitered through asbestos on a welghed Gooch crucible, and the precipitate washed with $100 \mathrm{cc}$. Water and $25 \mathrm{cc}$. ether. The cruclble and contents were dried overnight at $80^{\circ} \mathrm{C}$. then weighed to obtain the combined welght of precipltate and asbestos. Ihe contents of the crucible was now transferred to $1000 \mathrm{cc}$. of distliled water and placed on a shaking machine overnight. This suspension was then filtered through asbestos on a weighed Gooch crucible, the precipitate dried, and its loss in welght determined.

A second preparation of lead ethyl xanthate was treated In the same way, but was extracted in the cruclble with 1000 cc. of water Instead of being transferred from the cruclble and agitated with water.

Resuits

The $\mathrm{pH}$ of the lead ranthate suspension was $5.5-5.6$. the loss in welght in the flrst procedure was $198 \mathrm{mgms}$; and 
in the second was $120 \mathrm{mgms}$.

Gönclusions

Experimental difficulties make this procedure useless as a method for determining the solubillty of lead ethyl xanthate. The hydrophoble nature of the precipltate causes it to form a heavy scum on the surface of all suspensions, and to climb the walls of any vessel in which the preparation is placed, tendIng to cause loss of the material and leading to high results. Furthermore, the solubility of the asbestos used in the procedure is probably of the same order as that of the lead ethyl xanthate.

\section{Colorimetrie Procodure}

Preparation of lead ethyl ranthate

Preliminary tests showed that a colorimetric procedure Was sultable for determining lead in a saturated solution of lead ethyl xanthate. The following method was adopted for estimating the concentration of lead fons in equilibrium with solld lead ethyl xanthate in aqueous solution at various pH values.

Two solutions were prepared to contain $0.1474 \mathrm{gms}$. Iead nitrate and $0.1454 \mathrm{gms}$. potassium ethyl ranthate respectively In $500 \mathrm{cc}$. of solution. This allowed $2 \%$ excess ranthate over the amount required to react with the lead nitrate and form 0.2 gms. of lead ethyl xanthate.

The lead nitrate solution was poured into the ranthate solution, contained in a litre flask, whlle shaking the latter. 
The fine suspension of lead xanthate, which formed immediately, was then allowed to stand for two or three hours until it became flocculated and settled out, leaving a clear solution above the precipitate. In this condition, the precipitate showed no water-repelling tendency, and remalned settled at the bottom of the filask. If the flask was agitated, however, the precipitate tended to concentrate as a dry scum at the Pree liquid surface, and to cllmb the walls of the flask. Whe clear liquid above the preclpitate was decanted off, the precipitate washed on to a paper filter, and washed on the filter with $1000 \mathrm{cc}$. of distilled water. At no time during the washing process, was the preclpitate allowed to becone completely dry.

Ireatment of lead ethyl ranthate

After washing, the precipitate was transferred to a

1 lltre rubber-stoppered bottle, about 900 ca. of alstilled water added; then varlous amounts of elther N/10 KOH Or N/10 HCl to adjust the pH; and the total volume was made up to 1 litre. After a couple of minutes agitation, the initial pH of the preparation was measured, and the bottle and contents placed on a rotary shaking machine for a time interval varying from 16 hours up to several days. At Intervals the bottle was removed from the shaking machine and the $\mathrm{pH}$ of the contents measured.

Dotermination of $\mathrm{Pb}^{++}$concentration

Wen $1 t$ was desired to measure the $\mathrm{Pb}^{\text {in }}$ concentration in the preparation, the bottle was removed from the shaker, and 
the final pH reading was mado. The contents of the bottle wes flitered through asbestos on a Gooch chucible, and the plitrate placed in a l-11tre Pyrex beaker. After the adaltion or $2 \mathrm{cc}$. $6 \mathrm{~N} \mathrm{HCl,} \mathrm{the} \mathrm{flltrate} \mathrm{was} \mathrm{slowly} \mathrm{evaporated,} \mathrm{without} \mathrm{bolling,}$ to a volume of $5-10 \mathrm{cc}$. Ammonia was added to the solution unt II 1 was sIlghtIJ alkaline to IItmus. Whe red color of the Iltmus was then brought back by adalng glacial acetic acla and the solution was mado up with distilled water to a measured volume of $100 \mathrm{ce}$. This solution was used as the unknown In the subsequent colorimetric comparisons. Colorimetrie comparisons for lead

Standard solutions were prepared by dissolving 2.2881 gms. $\mathrm{Pb}\left(\mathrm{C}_{2} \mathrm{H}_{3} \mathrm{O}_{2}\right)_{2} \cdot 3 \mathrm{H}_{2} \mathrm{O}$ ( 1 ead acetate) In water and dIuting to $500 \mathrm{cc}$ inis solution (A) contalned 2500 mgms. $\mathrm{Pb}$ per 11tre.

10 co. of solution (A) were llated to 500 ce. to prepare a solution (B) containlng 50 mgms. Po per litre. 100 ce. of solution (B) were diluted to 500 cc to prepare a solution (C) containing 10 mgms. Pb per IItre. $10 \mathrm{cc}$. of solution (B) were alluted to $500 \mathrm{cc}$ to prepare a solution (D) contalning 1.0 mgms pB per $11 t r o$. When making a comparison with the colorimeter, $10 \mathrm{cc}$. of unknown solution was placed in one colorimeter cup, and $10 \mathrm{cc}$ of a sultable standard solution in the other: 4 drops of a saturated sodium sulfide solution were added to each cup, and the solutions stirred carefully.

The cups were now placed on the colorlmeter and several 
readings were taken, after which the cups were reversed, and a second set of readings obtained.

Fresh porttons of standard and unknown were now placed In the cups, so that the cup formeriy containing the standard solution contained the unknown, and a new series of readings was made.

These precautions were found to be essentlal in order to eliminate Instrumental errors.

From the above readings an average value was obtalned for the ratlo of the depth of standard solution to the depth of unknown solution. Ihis patio was mutiplied by the lead ion concentration in the standard solution to obtain the lead ion concentration in the unknown. The latter value, multplied by 10 , was taken to be the lead lon concentration in the origlnal saturated lead xanthate solution.

The method Is 11 lustrated bJ the following example: Unknown solution No. 11

Unknown in Gup \#I

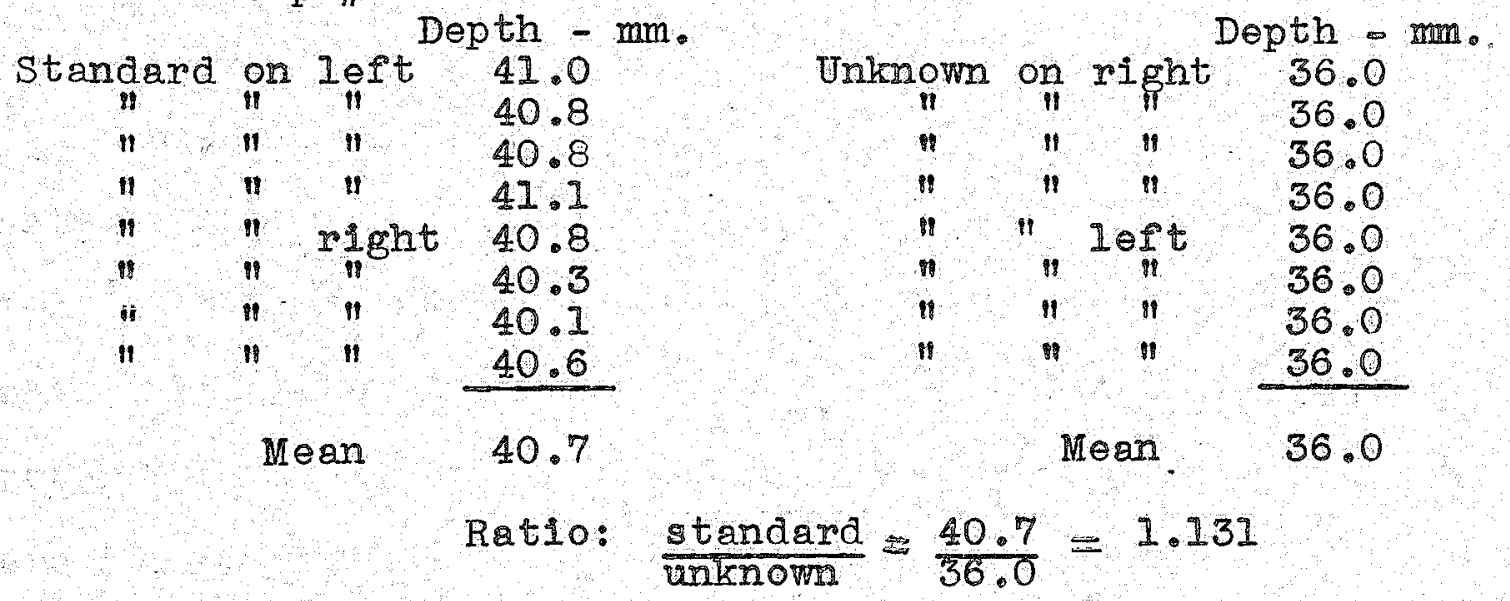


Unknown in Cpp \#2

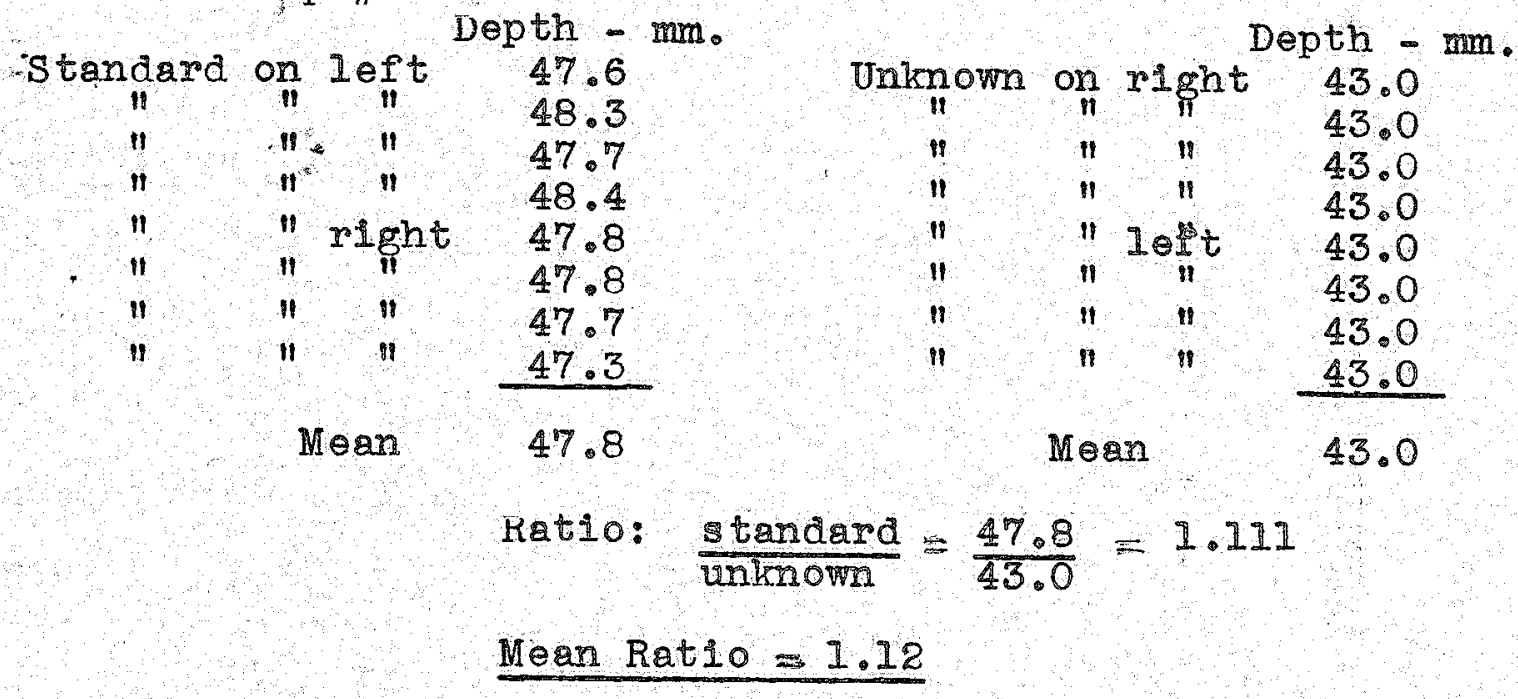

Standard solution $=10.0 \mathrm{mgm} . \mathrm{Pb}$ per litro

Unknown solution $=(1.12)(10.0)=11.2 \mathrm{mgm} \cdot \mathrm{Pb}$ per 1 .

Original solution $=\frac{(11.2)(100)}{1000}=1.12 \mathrm{mgm} . \mathrm{Pb}$ per. 1 .

Comparisons made between a particular unknown solution

and different standard solutions gave comparable results. It

was concluded that a correction for nom-linear absorbtion, as required by Beer's Law, was outside the limits of experimental error. In most comparisons, the depth of one solution did not exceed twice the depth of the other.

A blank determination on the distilled water used in the analyses showed a concentration of $0.12 \mathrm{mgms}$. Pb per $11 \mathrm{tre}$ It is felt that this value is probably too high, as it was determined during the early part of the work, before the colorimeter technlque had become standardized. Subsequent values were not corrected for the $\mathrm{Pb}$ concentration of the water, because of the doubtful accuracy of the latter, and bacause It was more desirable to determine the trend of $\mathrm{Pb}$ concentra- 
tion with $\mathrm{pH}$, than to evaluates the absolute values of the $\mathrm{Pb}$ concentration.

Results and Conclusions

The results of this work are glven in table $I$ and plotted in Fig. 1. From these results it is concluded that:

(1) The concentration of lead lons in a solution which is In equilibrium with solid lead ethyl zenthate depends on the pH of the solution.

(2) The lead ion concentration has a minlmum value of $0.15 \mathrm{mgm}$. Pb per 11tre at a pif of $8.0-8.2$. This corresponds to a solubility of lead ethyl xanthate at this pH of 0.33 mgms. per Itre. At pH values above or below $8.0-8.2$, the lead Ion concentration is greater.

(3) The solubility of lead ethyl xanthate in pure water, at a pil of $6.41 \mathrm{~s} 1.8 \mathrm{mgms}$. per I1tre.

(4) Lead ethyl ranthate, in the presence of water and hydrochloric acid, or potassium hydroxide, is slowly decomposed. This decomposition is accompanled by a decrease in pH in alkaline solutions, and an increase in acid solutions. the decomposition in the presence of potassium hyaroxide is also accompanied by a darkening of the lead ethyl ranthate. This darkening is more rapid in the more concentrated alkaline solutions.

Note

Samples of lead ethyl xanthate for determinations $19-22$ inclusive were prepared from equivalent quantities of reagents, all owing no excess xanthate. The lead concentrations obtained 
for these samples, as tabulated in Table 1 , are less than for comparable samples prepared with an excess of potassium ethyl xanthate. This is mentioned, Inasmuch as it may have a bearing on the solublilty figures obthined from the samples as prepared with excess renthate. It $1 \mathrm{~s}$ possible that excess xanthate ion may alter the lead xanthate surface in such a way that it will have a diferent solubility. Wo justify this assumption, further work is necessery. 


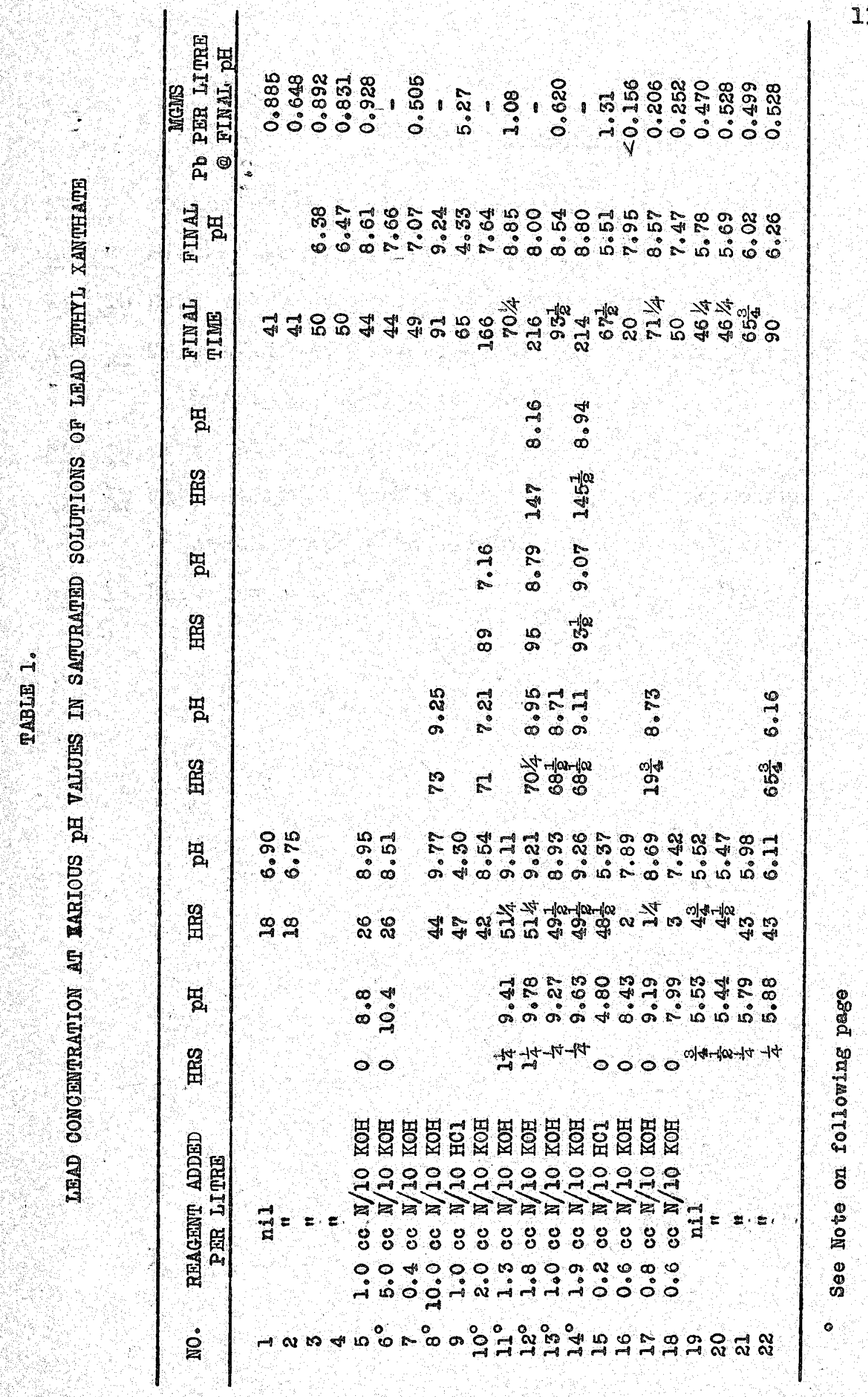




\section{NOTES RE TABLE 1 .}

No. 6 Yellowish initially; tumed black after 24 hrs. No. 8 Black after 24 hrs. No. 10 Dark after 24 hrs.; blackening with longer time 10. 11 Very slightly dark after $48 \mathrm{hrs}$. Final filtrate and precipitate both falriy dark.

No. 12 Darkened after 48 hrs. w0. 13 Very slightIy dark after 72 hrs. Flltrate and precipltate both slightly derk. No. 14 Dark after 48 hrs. 


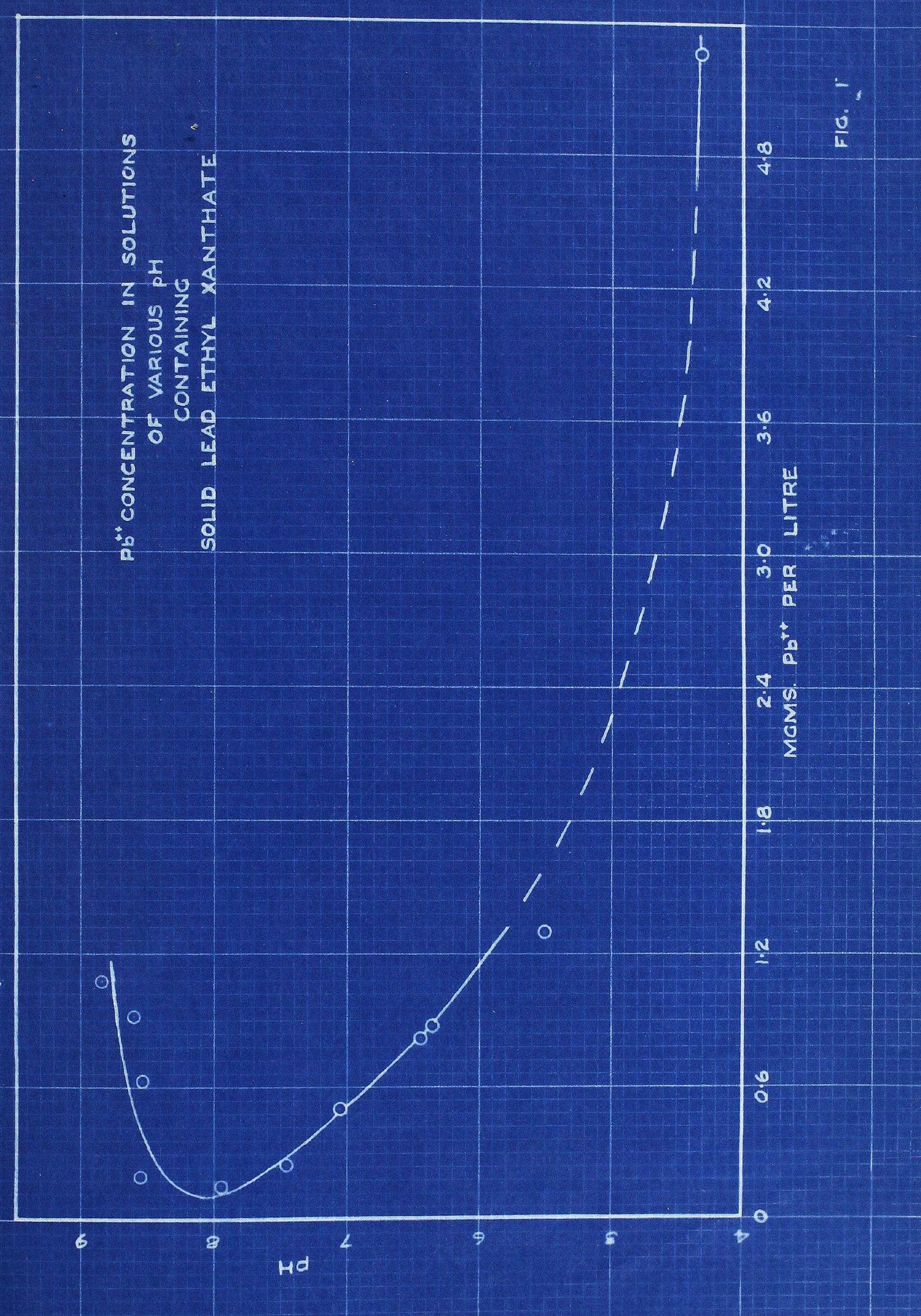




\section{SOLUBILITY OF CUPHOUS ETHYL XANTHATE}

Equivalent quantities of copper sulfate $\left(\mathrm{CuSO}_{4} \cdot 5 \mathrm{H}_{2} \mathrm{O}\right)$ (13.4 gms.) and potasslum ethyl zanthate $(17.3 \mathrm{gms}$.$) to react$ according to the equation:

$$
2 \mathrm{CuSO}_{4}+4 \mathrm{KEtX}-2 \mathrm{CuEtX}+(\mathrm{EtX})_{2}+2 \mathrm{~K}_{2} \mathrm{SO}_{4}
$$

and form $10 \mathrm{gms}$. cuprous ethyl xanthate, were disolved in water, and the solutions mixed. The precipitate was filtered and washed with water and with $95 \%$ ethyl alcohol, and stirred overnight in vater.

The precipitate was again filtered, extracted with alcohol and ether, and dried at a low temperature.

$0.1 \mathrm{gm}$. portions of ary cuprous ethyl xanthate, prepared as above, were agitated overnight with about 1 litre of water, then 11 tered; and the precipltate transferred to I litre bottles with $1000 \mathrm{cc}$. of distilled water, to give a solution having a pri of $7.1-7.4$. These preparations were agitated for $21 \frac{1}{2}$ hours. At the end of thls time the pH was 5.0-5.1. They were then piltered through filter paper and asbestos; but continued to pass through the filter as a cloudy liquid, probably an emulsion of dixanthogen.

2 cc. $6 \mathrm{~N}$ hydrochloric acld was added to the filtrate, which was then eveporated almost to dryness, made just alkaline with ommonia, and then bolled to expel excess ammonia. 2 cc. amonium nitrate solution ( $100 \mathrm{gm}$. per litre) were added, and the solution was made up to a volume of $60 \mathrm{cc}$. 
A colorimetric comparison was attempted between a $10 \mathrm{cc}$. portion of the above solution, and a $10 \mathrm{cc}$. portion of a standard copper sulfate solution, contalning $4 \mathrm{gm}$. amonium nitrate per 11tre, efter adding 2 drops of potassium ferrocyaride solution ( $40 \mathrm{gms}$. per litre) to each. It was found, however, that insuffleient color was developed to make this procedure feasible.

Further work on the solublity of cuprous ethyl xanthate was not attempted. 


\section{METHODS FOR MHASURING FLOATABILITY}

If the premise is accepted that a solid is floatable when Its surface is hydrophoble; and that it may possess this property to a greater or less extent; the question arises: How can this degree of water-repelience or floatability be measured? It has been determined previousiy in various ways. The floatablity has been measured as the percentage of finelyground solld recovered in a flotation froth, under perticular conditions approximating those existing in industrial flotation cells. The extent to which a surface is hydrophobic has been measured by the magnitude of the contact angle between an alr-bubble and the submerged solld surface; or between a water drop and the solld surface in alr. To a lesser extent, the displacement pressure of water by $a 1 \mathrm{r}$, and the heat of wetting of the surface have been used as measures of ploatability. the contact angle is probably the most fundamental meas ure of the state of a solld surface, and is a derivable funetion of the solld interfacial tension. However, the concentation of a IInely - ground solld at a liquid-gas interPace is a more alrect measure of floatability. In the current work it was decided to use the latter method. It became necessary, therefore, to develop an apparatus to make small scale flotation tests, which woula permit close control of as many as possible of the variables inherent in the process. It was at first thought that some information might be obtained by allowing single alr bubbles of known size to rise 
through a pulp of mineral in water, and determining the concentration of mineral in the upper part of the pulp, as a function of the total interfacial area represented by the bubbles. No satisfactory method could be devised, however, to remove the concentrated solid before the alr bubbles collapsed and allowed the solid to settle back into the pulp. In order to hold the water-repellent mineral above the pulp, it is nocessary to maintain a froth zone in which the individual alr bubbles are rising with a velocity greater than the effective downward velocity of the mineral partieles. With this in mind, a pneumatic glass flotation cell (FIg. 2) was dereloped, whlch Is belleved to have certain advantages for the present work over existing types of laboratory cells. The all-glass construction facilitates cleaning, and minimizes contamination of the pulp by the material of the cell. In practice it is found necessary to clean the sintered plate after each man by forcing aqua regla through it, to remove small sulfide particles which tend to clog the pores. Alr supply is easily regulated. Elimination of mechanical agitation, othor than by the stream of alr bubbles allows eloser reproduclbility of this varlable than is possible when on impeller is used. 


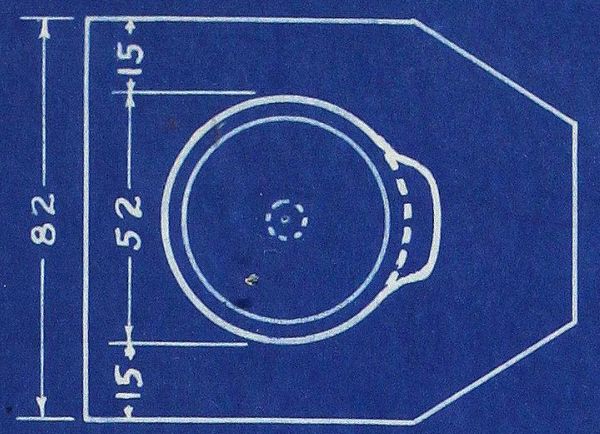

FLOTATION CELL

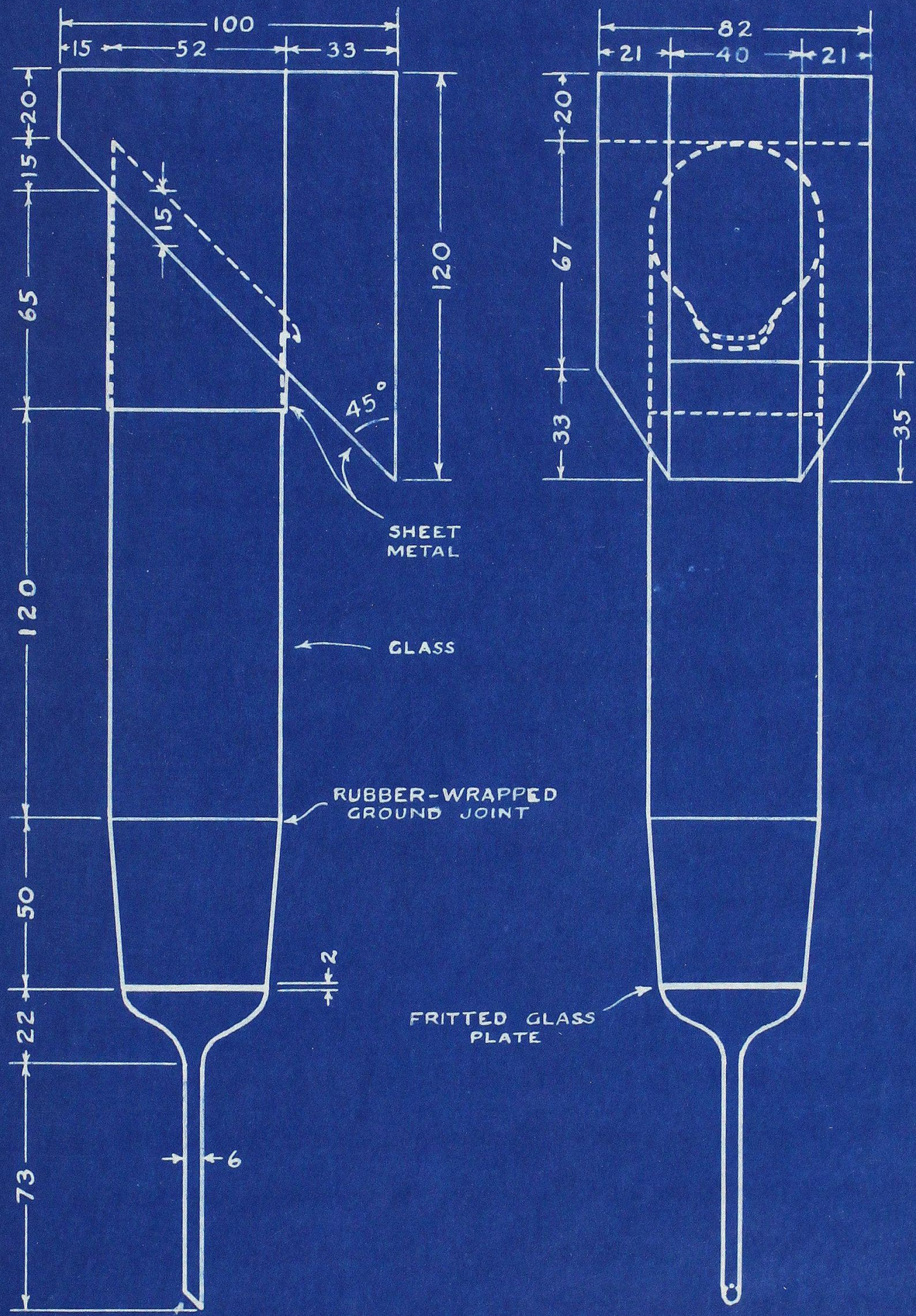

HALF FULL SIZE

DIMENSIONS IN MM.

$+21+-82 \rightarrow+21+$ 


\section{FLOTATION WITHOUT REAGENTS}

Procedure with preclpitated fbS, galena, and silice

- The cell was used first to study the flotation of synthet1c lead sulfide in distllied water, using no frother or other reagents.

The cell was set up and provision made to introduce a constant stream of water (about 5 cc. per minute) at the top, to cause an overflow. Approximately 5 gram portions of lead sulfide were prepared by saturating $500 \mathrm{cc}$. of a water solution of 7 grams of lead nitrate with hydrogen sulflde gas, and washIng the precipitate eight times by decanting off successive 500 ce. portions of distilled water. A 5 gram portion of lead sulfide was transferred to the cell, and the pulp volume made up to about $300 \mathrm{cc}$. Sufflcient alr pressure was meintained to prevent the liquid running through the sintered plate, but insuffleient to cause any overflow. The pH of the pulp was taken, and the air pressure increased unt1l overflow was just about to occur. The feed water was turned on, and the overflow collected for 10 minutes, after which the feed water was shut off, the air tumed down, the volume of pulp and conce $\mathrm{n}$ trate noted, and a pH measurement made on the pulp. The "concentrate" overflow, and the "tallings" pulp remaining in the cell were filtered through Gooch filters, and the welghts of solld in each were measured. From these weights, the total weight of lead sulfide used, the percentage of this weight recovered in the overflow, and the percentage recovered per 
unit volume of the overflow were calculated. The results of this series of runs are given in Table 2.

In the above tests a certain amount of pulp overflowed with the incipient froth. The pulp mechanically carried a definite welght of solid into the overflow. If the solid used is hydrophoblc, the observed recovery should be greater than the mechanical recovery; and if hydrophllic, the observed recovery should be less. In order to calculate the mechanical recovery, it is assumed that, at any instant, the concentration of solid in the overflowing pulp is the same as in the body of the pulp. It is also assumed that the initial volume of puip does not change. This implies that the feed water causes an overflow of a volume of pulp equal to that of the vater added. Let $A$ ce. be the constant rolume pf pulp In the cell, and $G$ gms, be the original weight of solids in the pulp. After $n$ cc. of feed water has been added, an equal volume of concentrate, containing $x \mathrm{gms}$. of sollds has overflowed. After $x$ gms. of solid has overflowed, the Instantaneous concentration of sol1d in the pulp will be $\frac{G-x}{A}$ gms. per cc. If a volume an cc. now overflows, it will contain dx gms., and the concentration of solld in the overflow will be $\frac{d x}{d n}$ gms. per cc. It has been assumed that these concentrations are equal. Therefore:

$$
\begin{gathered}
\frac{d x}{d n}=\frac{G-x}{A} \\
\int_{G-x}^{x} \frac{d x}{\frac{1}{A}} \int_{0}^{n} d n
\end{gathered}
$$




$$
\text { In } \begin{aligned}
\frac{G}{G-x} & =\frac{n}{A} \\
x & =G\left(1-\frac{1}{e^{n / A}}\right)
\end{aligned}
$$

From thls equation, the weight of solid ( $x \mathrm{gms}$.$) overflowing$ "mechantcally" has been calculated for the various tests, and the results tabulated in Table 2 and subsequent tables.

From the work with preclpltated lead sulfide certain conclusions may bo drawn. If all varlables (pulp volume, air pressure, welght of solids, and volume of feed water added) are kept constant in a series of runs; the volume of overflow is necessarliy constant, and the weight of sollds recovered In the overflow is a reproducible flgure. If the air pressure, Inftial pulp volume, and volume of feed water added are kept constant in a series of runs, but greater wolghts of solla are used in the cell, the pulp volume tends to increase during a run, and the final volume of overflow is less. At the same time the recovery increases, but the recovery por unit volume of overflow tends to remain falrig constant. The latter figure, because it tends to take care of slight unavoldable variations In overflow volume, has been used as the final figure in each run. The alr pressure which must be applied to just cause the cell to overflow depends on the volume of pulp in the cell. A small pulp volume requires a high alr pressure, and vice versa. At the same time, the total recovery, and the recovery per unit volume of overflow are increased by the use of a smaller pulp volume and a greater alr pressure. In all cases, the 


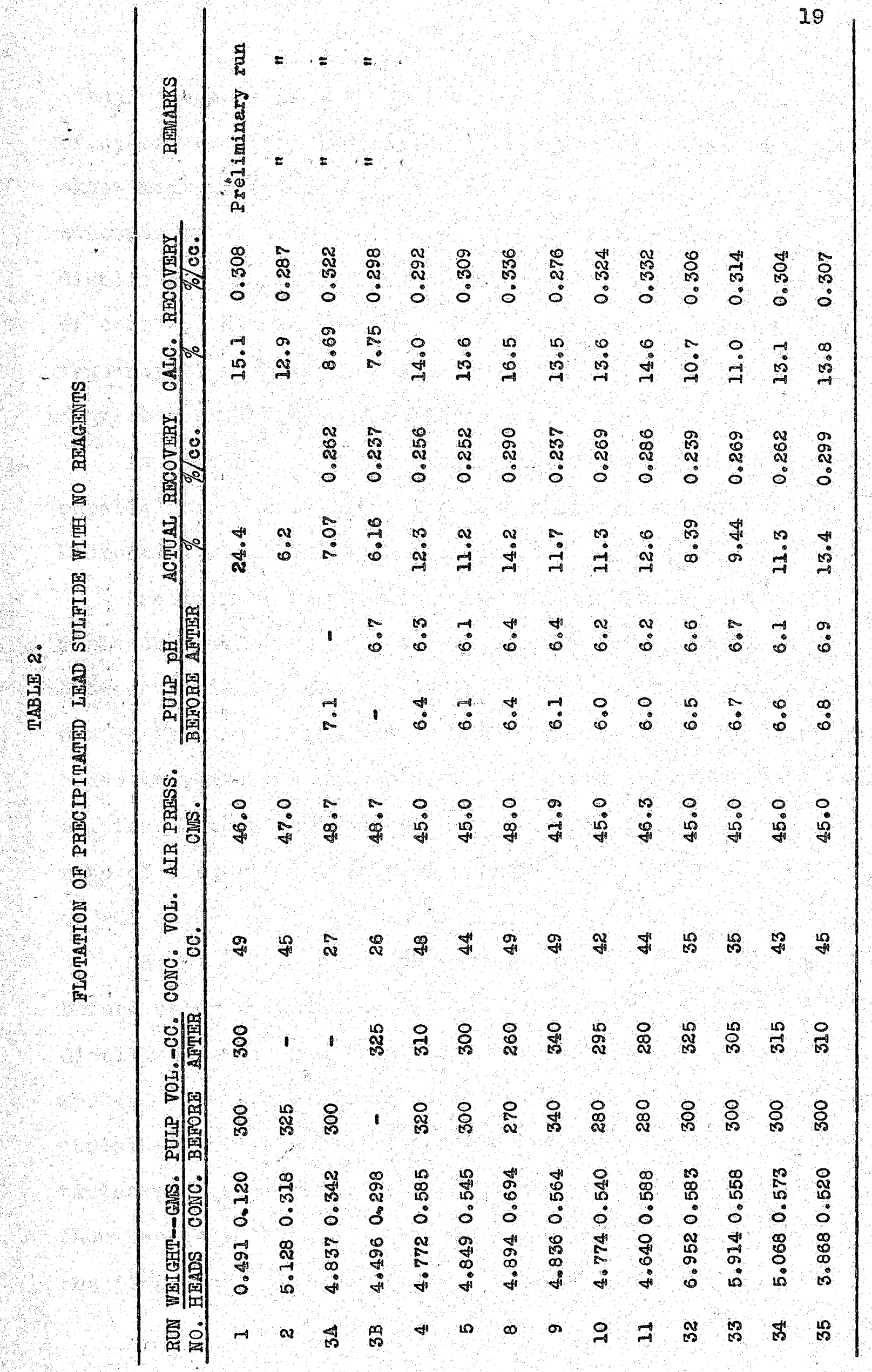


actual recovery is less than the calculated recovery per ce. of orerflow. Ihis Indicates that, under the conditions of the experiment, preclpitated lead sulfide shows no tendency to concentrate at the alr-Ilquid Interface; that is, It does not display any inherent floatability. This conclusion assumes, of course, that in the process of overflowing, there is no tendency at the overflow lip for the solid to be held back to a greater extent than the Ilquid.

In an endeavor to make this latter as sumption unnecessary, parallel tests were made with lead sulfide, galena, and an hyarophilic material such as silica.

Preliminary tests on various silica samples, given in Table 3 showed that it was necessary to make comparisons between simliarly slzed materials. A water elutriator (Fig. 3) was built, and callbrated by the rising velocity of water produced at various stopcock settings. This apparatus gave veloclties up to $26 \mathrm{~cm}$. per minute, corresponding to the settling rate of a quartz particle of approximately $0.07 \mathrm{~mm}$. diameter, or 200 mesh.

Galena, for use in subsequent tests, was prepared just before using by grinding 8 to $10 \mathrm{grms}$. of $1 / 4^{\text {n }}$ mineral under dist1lled water in a carefully cleaned porcelain or agate mortar, and intermittently washing fine material into the elutriator unt1l the entire portion had been transferred. Particles with a settling rate of 3.5 to $9 \mathrm{~cm}$. per minute were then separated by the elutrlator, and transferred at once to the flotation cell. Portions of an assay grade of powdered 


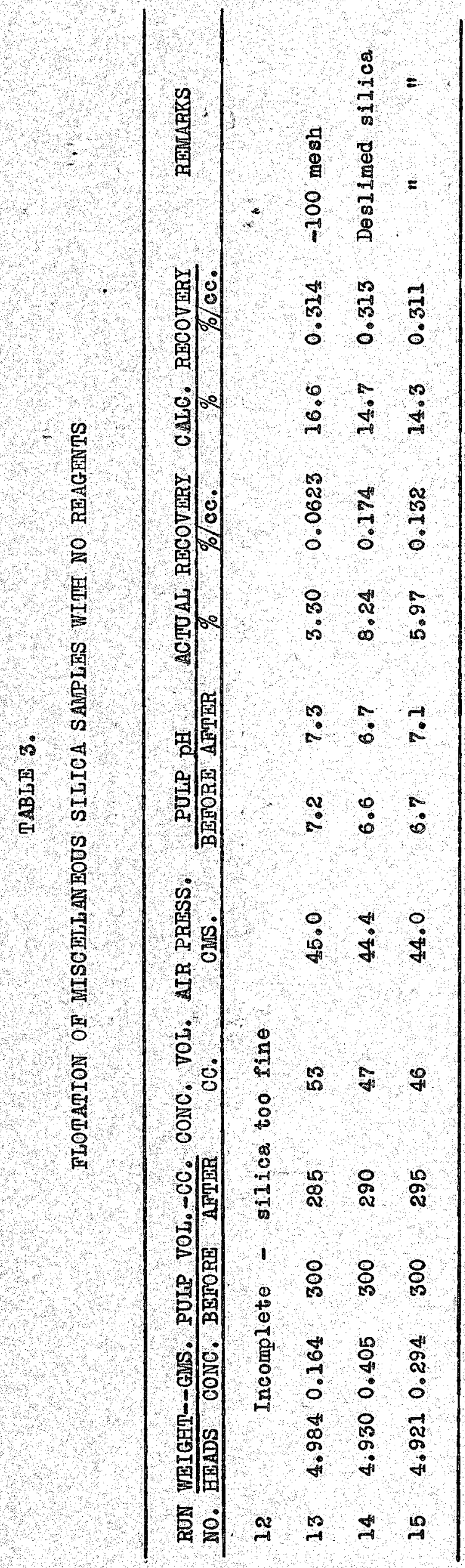




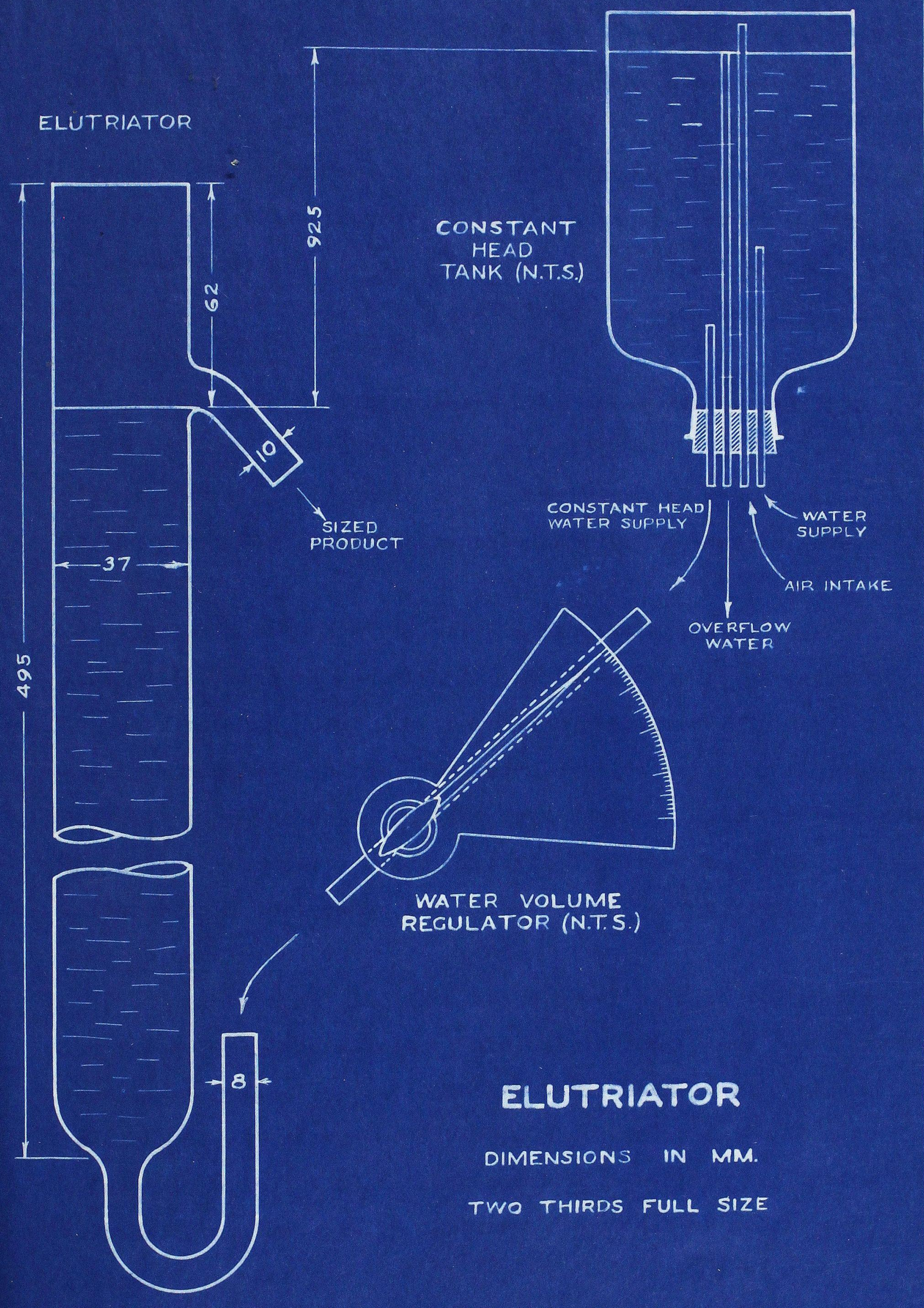

FIG. 3 
s1lica were placed in the elutriator, and the fraction with a settling velocity in the range $3.5-9 \mathrm{~cm}$. per minute was removed. This portion was digested in hydrochloric acid, washed free of ferric chloride, dried, and bottled until required. No attempt was made to size the precipitated lead sulfide, as it consisted of flocs which would break up when the suspension was agitated.

The results of tests made on the sized galena and silica, using the same procedure as followed for lead sulpide, are given in Table 4 and Table 5. A comparison of results is shown by the graph FIg. 4, in which only comparable results have been plotted.

lables 6 to 8 are the results of miscellaneous runs on lead sulfide and silica with the addition of various reagents to the flotation pulp. The runs made with lead sulfide in a pulp containing $25 \mathrm{mgm}$. potassium ethyl xanthate per litre, over the pH range 3 to 10 , show that ranthate slightly increases the actual recovery per cc. Insufflelent work was done in this series to determine the effect of $\mathrm{pH}$ on recovery. Conclusions

It may be concluded from these results that, within the limits of experimental error, the galena and silica particles investigated have the same floatablilty; hence, that this specimen of galena has no inherent floatability. It is also evident from Fig. 4 that the behavior of precipitated lead sulfide is not materially different from that of galena or silica. 


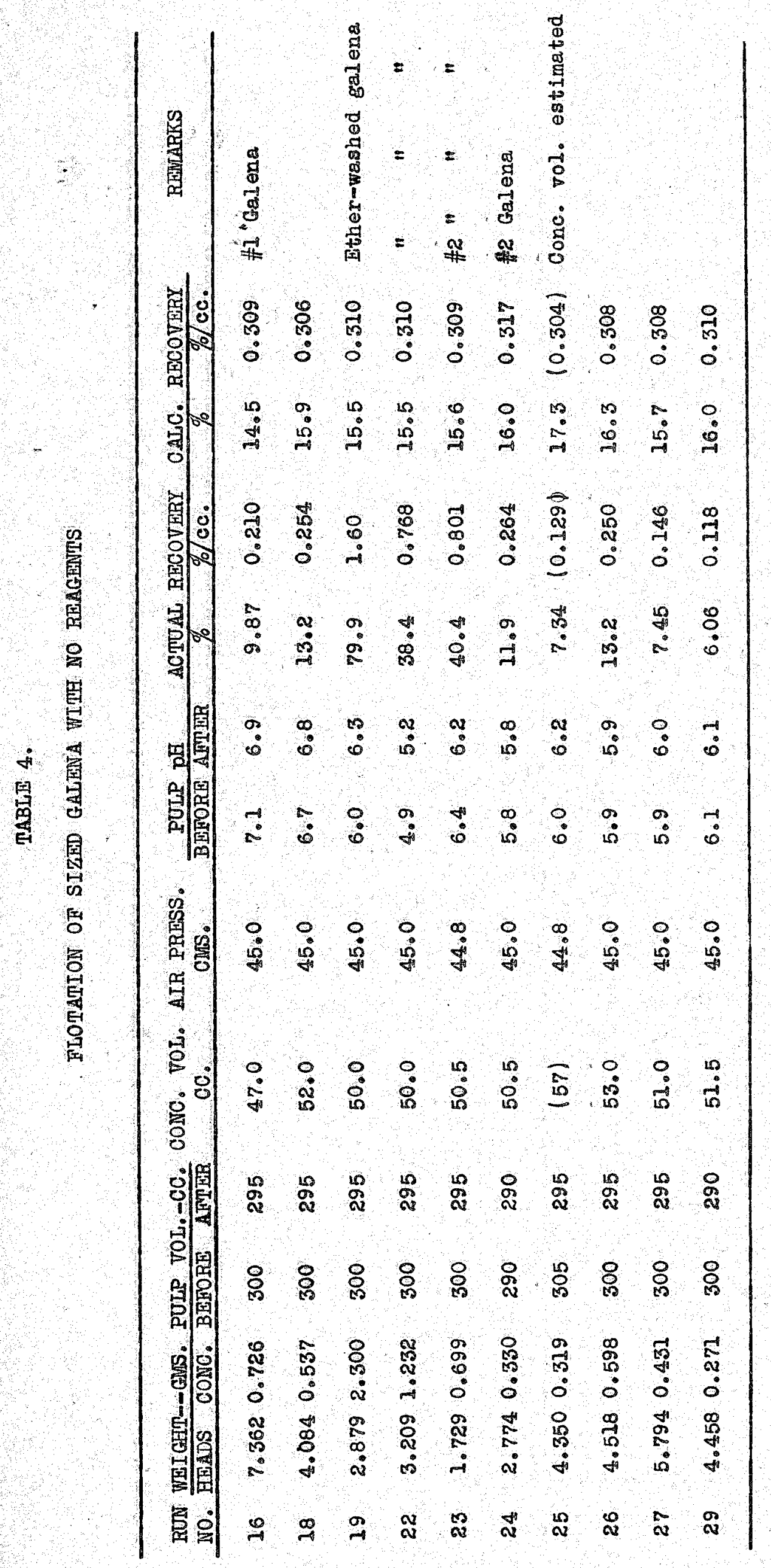




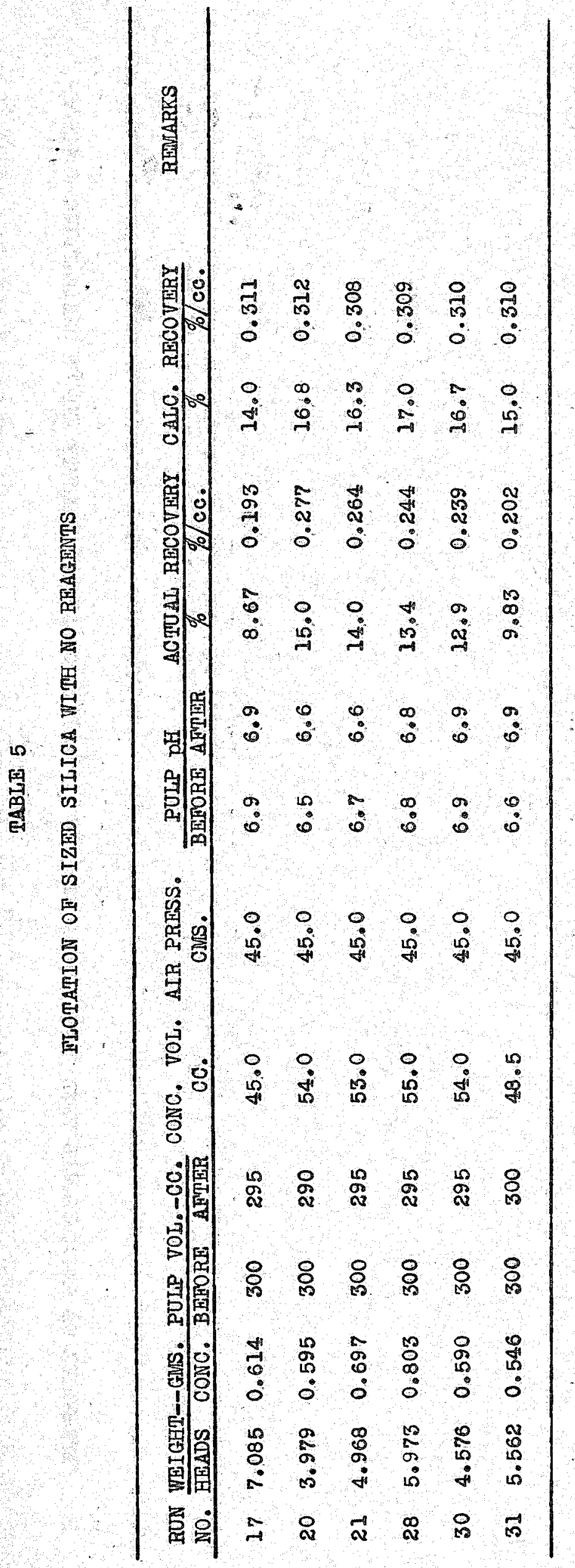




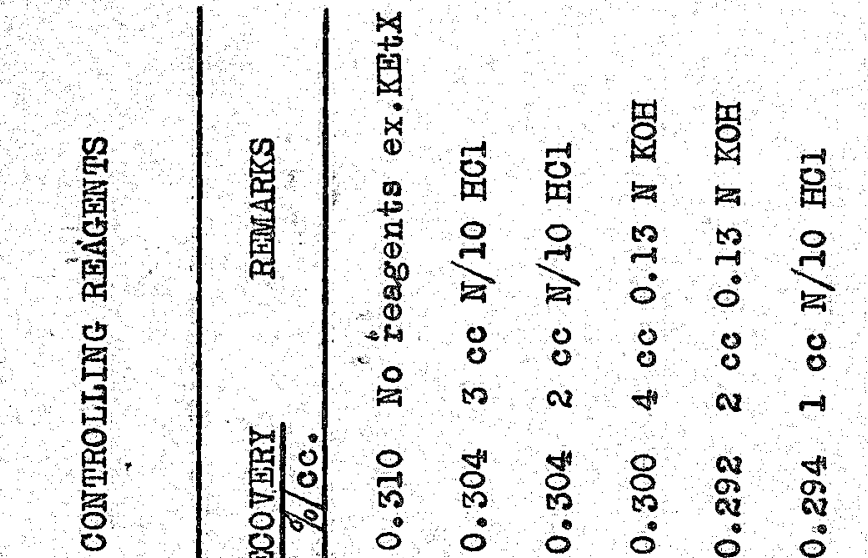

$$
\begin{aligned}
& \text { : } 000 \text { : } \\
& \text { 哭 } \\
& \text { 星 } \\
& \text { 형 }
\end{aligned}
$$

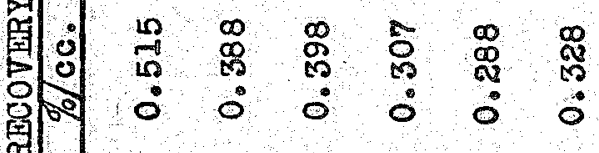

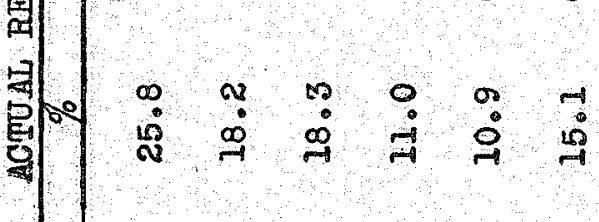

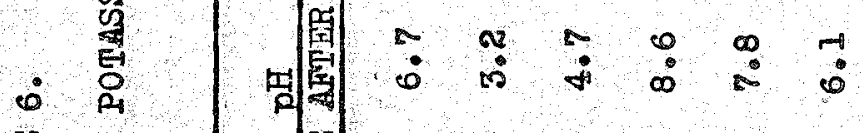

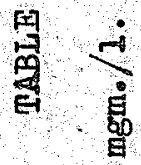

$$
\begin{aligned}
& \text { 遗部 : } \\
& \stackrel{2}{\Omega} \\
& \text { 罩 } \\
& \text { 造 } \\
& \text { 뭄 } \\
& \text { 舅是 } \\
& \text { 홍 }
\end{aligned}
$$

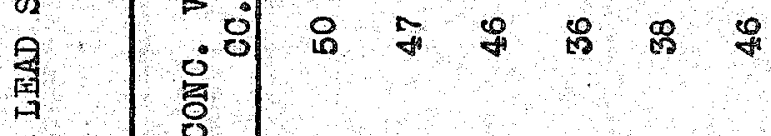

$$
\begin{aligned}
& \text { 貝 谓 } \\
& 9 \text { 연 }
\end{aligned}
$$

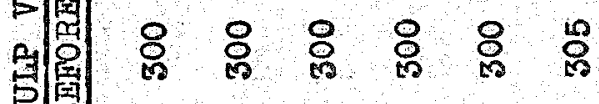

$$
\begin{aligned}
& \text { 외이 }
\end{aligned}
$$

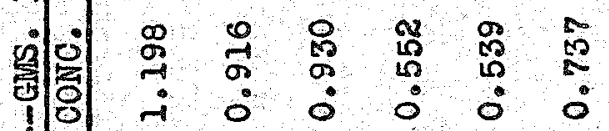

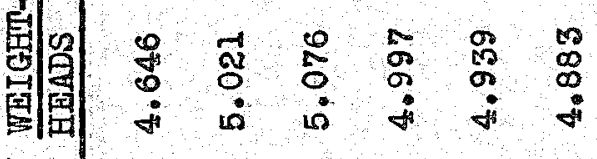

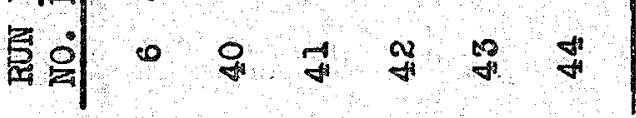




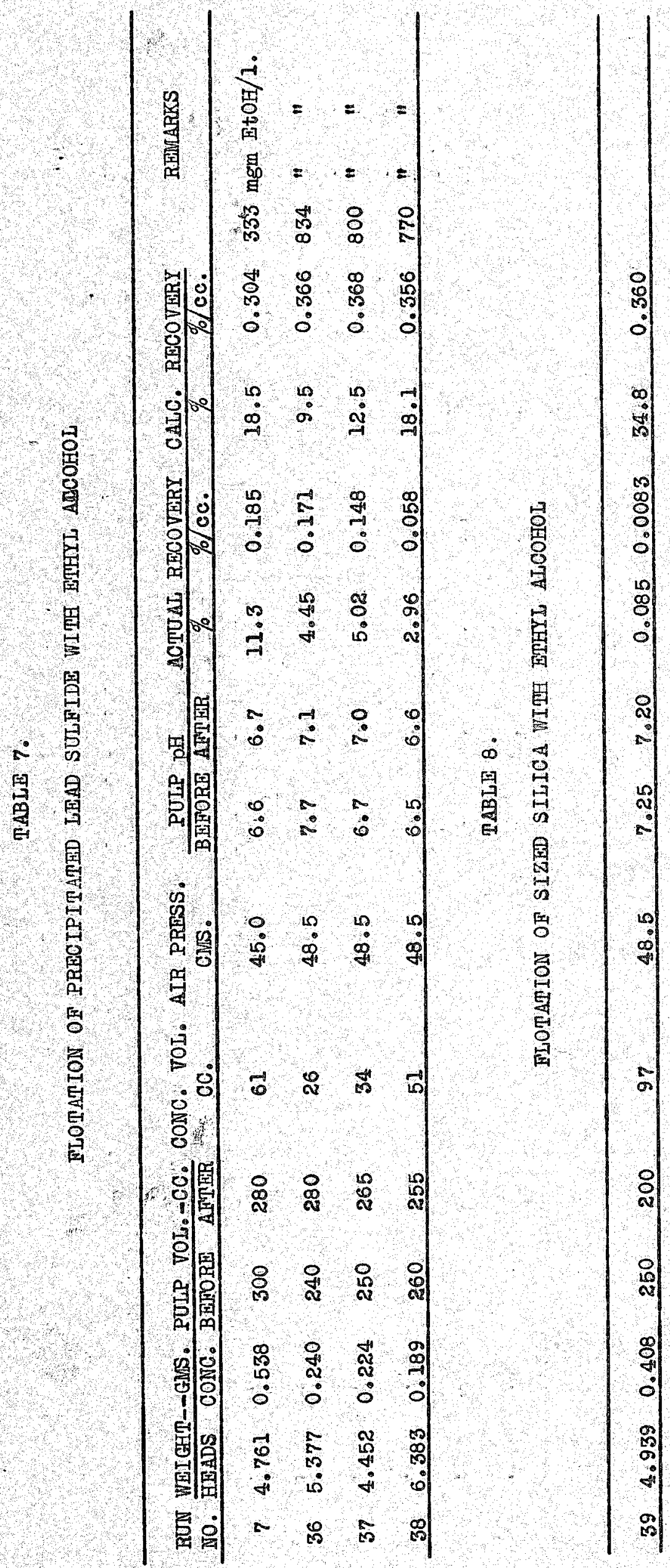




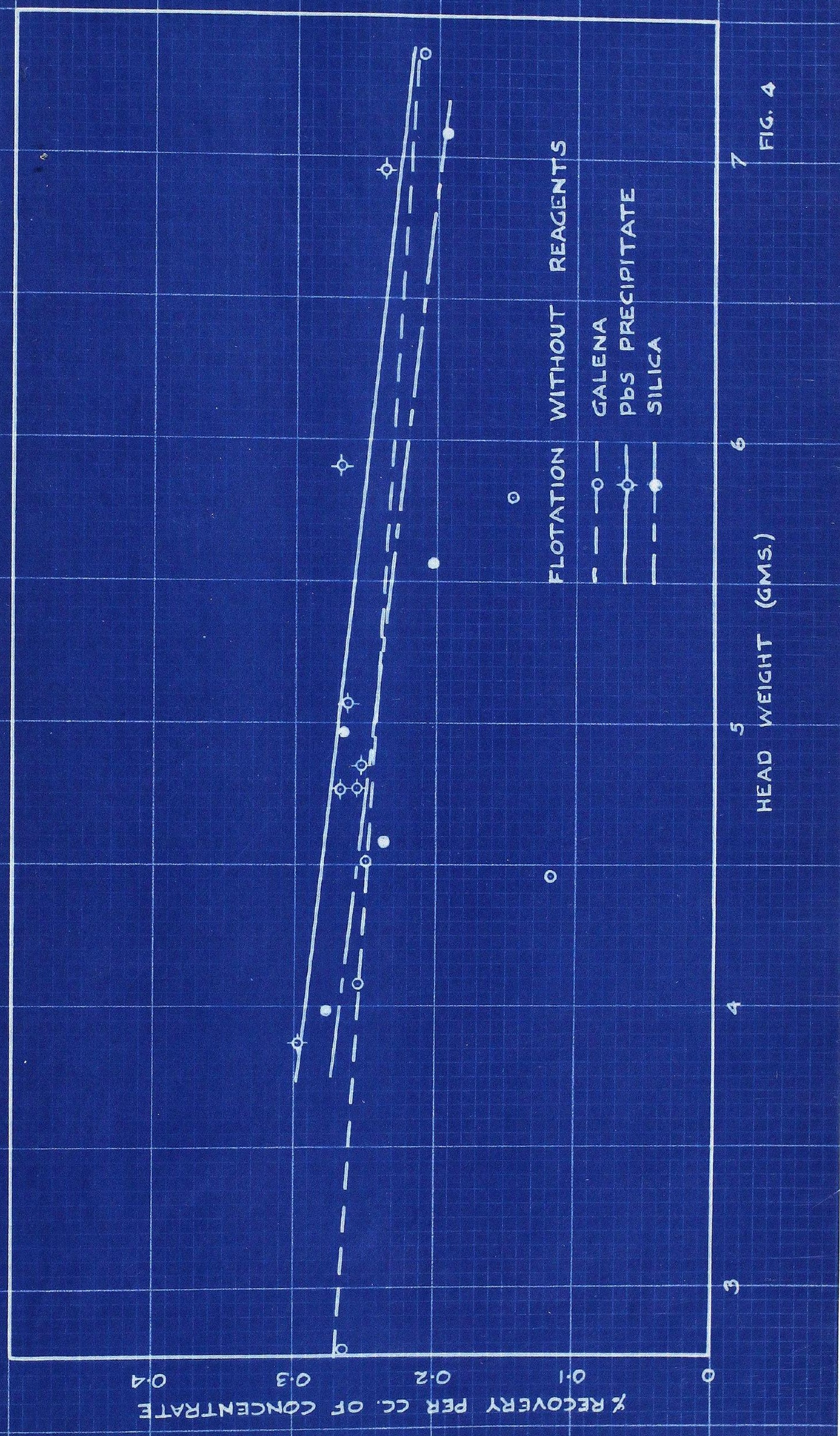


FLOTATION WITH TERPINEOL AIONE (Inherent Floatability)

The runs with lead sulfide and silica, in which ethyl alcohol was used as a frothing agent (Tables 7 and 8 ) show that the frother materially decreases the recovery per ce. by decreasing the "mechanlcal recovery". While ethyl alcohol does not give a satisfactory flotation froth, the rung outined in Tables 7 and 8 suggested the advantage of using a frothing agent to decrease to a minimum the mechanical recovery of an hydrophilic solld, while allowing maximam recovery, with small overflow of liquid, of a solid which is hydrophoblc. The following tests wero made using terpineol as a frother. Procedure with precipitated lead sulfide

Approximately $5 \mathrm{gms}$. of precipitated lead sulfide in $150 \mathrm{cc}$. of pulp, containing 5.3 mgms. terpineol per litre was placed in the flotation cell, and air pressure applied sufficient to form a coplous froth.

No trace of lead sulfide appeared in the froth. Procedure with Galena \#2 (Run No. 45)

A11 apparatus was carefully cleaned with chromlc acid and distlied water.

A sample of Galena \#2 was ground under distilled water, sized, and a $1.82 \mathrm{gm}$. portion, having a settling rate of 9 - 25 cm. per minute transforred to the flotation cell. The pulp volume was made up to $150 \mathrm{cc}$ and $3.5 \mathrm{cc}$. terplneol solution ( $1 \mathrm{cc} .=0.25 \mathrm{mgm}$ ) added to make the concentration of 
terpineol $5.8 \mathrm{mgm}$. per litre.

In this solution, containing no acias or alkalis; and in the presence of hydrochloric acid or sodium hydroxide, over the pH range 3 to licthere was no trace of galena in the froth. Procedure with Galena \#5 (Run No. 58 )

All apparatus was carefully cleaned with chromic acid and distilled water.

A sample of Galena 75 was ground under distilled water, sized, and the portion having a settling rate of $9-25 \mathrm{~cm}$. per minute transferred to the flotation eell. The pulp rolume was made up to $250 \mathrm{ce}$, and $4 \mathrm{cc}$. terpineol solution ( 1 ec. $=0.25 \mathrm{mgm}$ ) added to make the concentration of terpineol 4 mgms. per litre. Time was measured from the time of ading terpineol. Three five-minute concentrates were taken off, as shown below, with the addition of 4 ec. of terpineol solution before concentrates \#2 and \#3 were removed.

$$
\text { Run-No. } 58
$$

Product

Weight (gms.) pH PuIp \% Recovery

Concentrate \#1 ( $1-6$ min.)

1.042

4.04 36.8

$n$ \#2 (13-18 min.)

0.202 $4.04-4.13$ 7.06

n \#3 $(30-35 \mathrm{~min}) \quad$. 4.13 3.24

Tails

1.503 52.9

Heads 2.839 $100 \div 0$

Conclusions

Procipitated load sulfle is not floated by terpineol a.lone.

Iwo samples of galena, both apparently pure specimens, 
differ materially in their floatability with terpineol alone. of the two samoles studied under simliar conditions, the first has no inherient floatabliity, whlle the second has an appreciable ploatabil1ty.

The galena specimen showing no natural floatability, in view of earlier observations, Jielas lead lons to a greater extent than the other specimen, when placed in water.

Becarse of these conflicting results, no conclusion can be arawn at this time, as to the Inherent floatability of galend. It is probable that the state of oridation of the galena surface deternines lts foating characterlstios with terpline al ane. As a tentative hypothesis it is suggested that the surfaco of a pure lead sulflde crystal (whlch might be obtalned by grinding galena under oxygen-free water for contact angle measurements) may be non-floatable; but that adsorption of atmospheric orygen may make such a surface floatable. If the adsorption continues to such a point that the surface becomes essentialiy one of lead sulfate, or loed oxlde, tho character of the mineral surface is again hydrophI1:

Thls hypothosis might be tested by preparing and floating galena In the presence of some inert gas, although elaborate precautions would bo necessary to insure the purity of the lead sulfide surface, the total exclusion of oxygen, and the elimination of any possiblo contaminants. 
- FLOTATION OF XANTHATE-TREATED GAIENA WITH TERPINEOL

Procedure

- Galena was ground and sized as before, and the portion having a settling rate of $9-25 \mathrm{~cm}$. per min. $(35-50$ microns measured particle size) was transferred at once to a beaker and carefully stirred for $4 \mathrm{~min}$. wh th $250 \mathrm{cc}$. of potassium ethyl xanthate solution (25 mgm. per l1tre). The solution was poured off, and the mineral again treated for 4 min. with 250 ce. of fresh xanthate solution of the same concentration. This solution was poured off and the galena stirred for $4 \mathrm{~min}$. with $250 \mathrm{cc}$ of distilled water, after which the wash water was decanted off, the galena transferred to the flotation cell, hydrochloric acid or potassium hydroxide added to control the pis, and the volume of pulp brought up to $250 \mathrm{cc}$. While maintaining a low pressure of air.

The pulp was alr-agitated in the cell for 5 - 10 minutes, While initial pH readings were made at frequent intervals. 4 cc. of terpineol solution ( 250 mgm. per litre) wes edded to make the terpineol concentration in the pulp $4 \mathrm{mgm}$. per Ittre. the air pressure was brought up to $45 \mathrm{~cm}$ of mercury, and the overflowing froth collected for 5 min. A fine stroam of water (about $5 \mathrm{cc}$. per min.) was used to wash down the Instae glass walls of the cell during the run, and to assist the froth to overflow. After the $5 \mathrm{~min}$. period, the alr pressure was lowered to stop the overfiow; a series of $\mathrm{pH}$ measurements was made on the pulp remaining in the cell; and 
the volume of pulp in the cell was noted. The concentrate and tallings pulps were filtered through Gooch crucibles; the crucibles weje dried overnight at approximately $80^{\circ} \mathrm{C}$, and weighed. The recovery was calculated as the percentage welght of total material recovered in the proth overflow.

The pH at the beginning and end of each man was obtalned by plotting pH versus time, and interpolating.

Results

The results of thls series of tests are given in Table 9 and Fig. 5. Runs numbered 45 - 56 were made on \#2 Galena; runs \#57-\#60 on No. 5 Galena.

Remarks

The xanthate solution, after it was used for treating No. 2 Galena, became quite cloudy; but remained practically clear with No. 5 Galena. It would eppear that the former sample may have contained an appreclable amount of soluble lead compounds which reacted with the xanthate solution to form a suspension of lead ethyl xanthate. Subsequent tests (Runs 45 and 58 ) also showed that the two samples behaved differentig in flotation.

In all runs mede, the $\mathrm{pH}$ in alkaline solutions tended to drop; and in acid solutions, to rise during the course of the run. This change of pH with time is show by Fig. 6 and Fig. 7. In only two cases (Runs 53 and 55 ) did the $\mathrm{pH}$ tend to reach a constant value of $7.4-7.5$. The rate of change of $\mathrm{pH}$ with time appears to be greatest when the initial concentration of alkali ig small. It is significant that this 


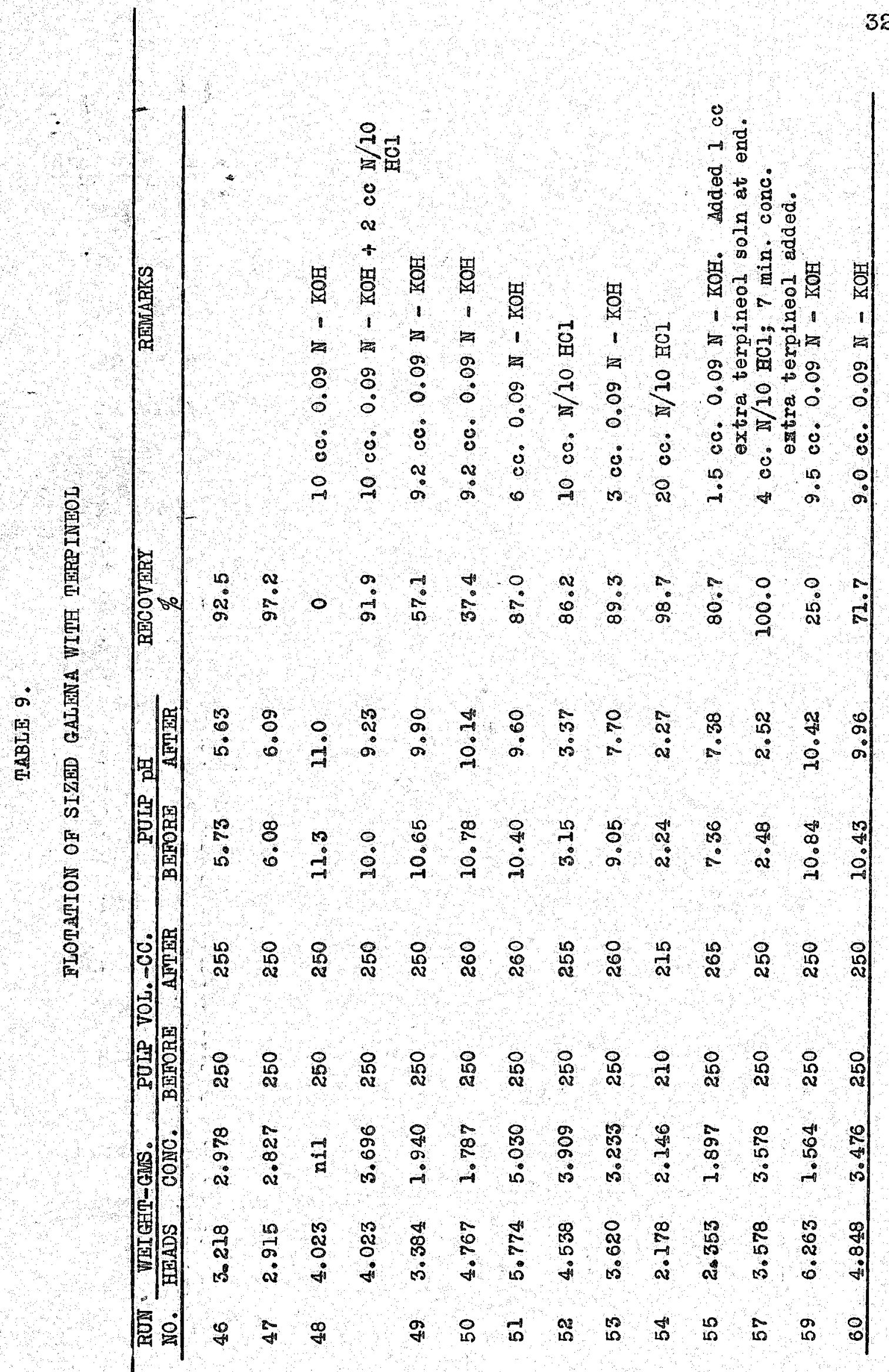




\section{NOTES RE TABLE 9.}

Run \#48 Measuring time from the addition of terpineol, there was no trace of galena in the froth at $7 \mathrm{~min}$. ( $\mathrm{pH} \mathrm{10.91);}$ but a small amount was visible at $8 \mathrm{~min}$. (pH 10.82). At $11 \mathrm{~min} .2 \mathrm{cc} . \mathrm{N} / 10 \mathrm{HCl}$ was added to reduce the pH to 10.0 , and a concentrate was taken off during the interval between 14 and $19 \mathrm{~min}$. The final pH observed at $14 \mathrm{~min}$. was 9.23 . kun \#49 As the pH continued to drop after the run was completed, more galena appeared in the froth.

In this run, the concentrate liquid was jellowish in color, but clear.

Run \#54 An appreciable quantity of lead sulfide was recovered from the tallings filtrate by saturating it with hydrogen sulfide gas after the run was completed.

A microscopic examination of the unfloated galena in the tailings showed it to contain a considerable amount (30 to $50 \%$ ) of a white, s111ceous-appearing mineral. kun \#57 The pulp in the cell was free of galena at 5 min. The longer time and extra terpineol was used to cause the galena already in the froth at $5 \mathrm{~min}$. to overflow.

A negligible amount of lead was detected in the tallings flitrate by saturating it with hydrogen sulfide. kun \#59 The talings filtrate was very dark in color. 


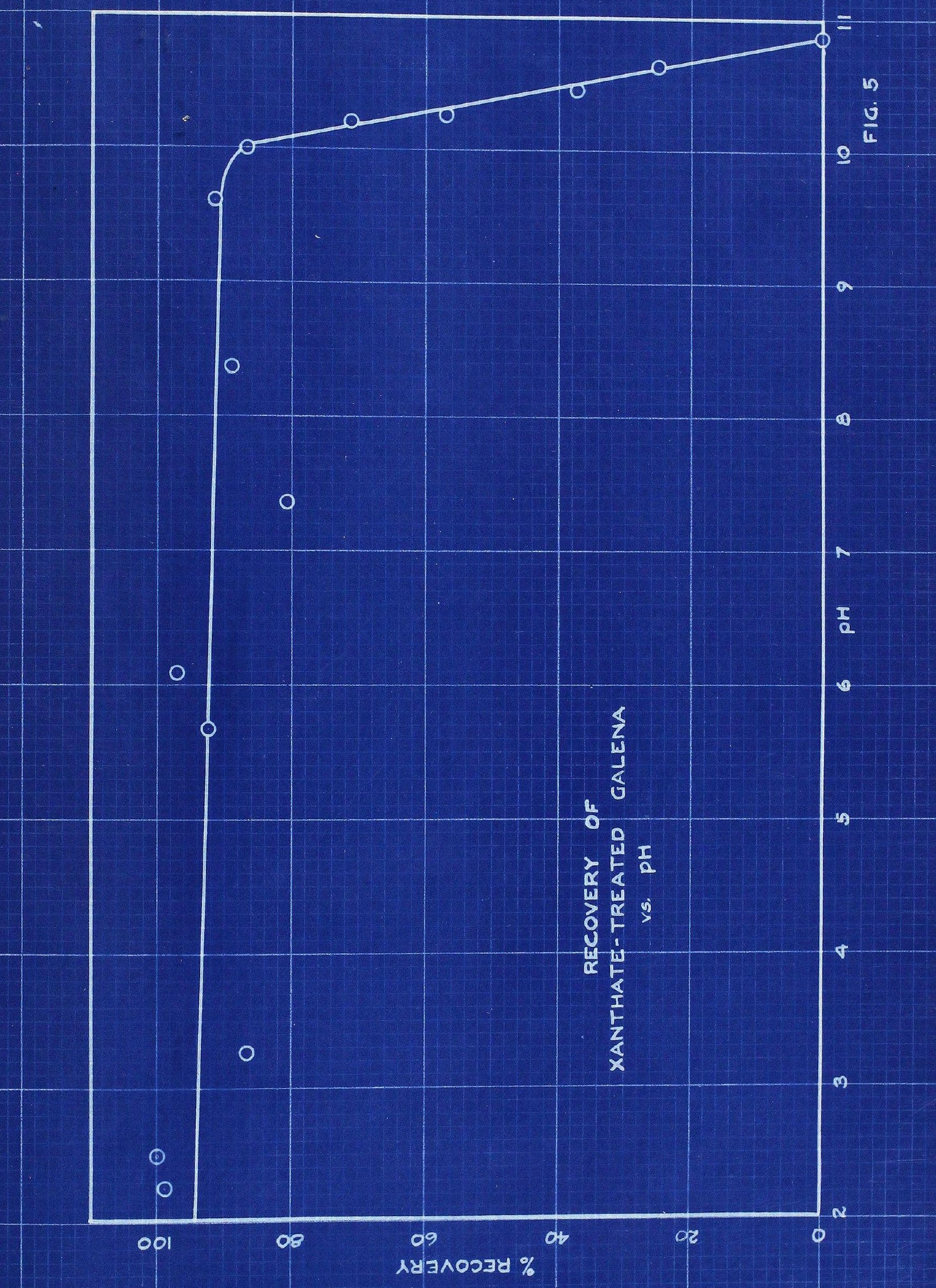




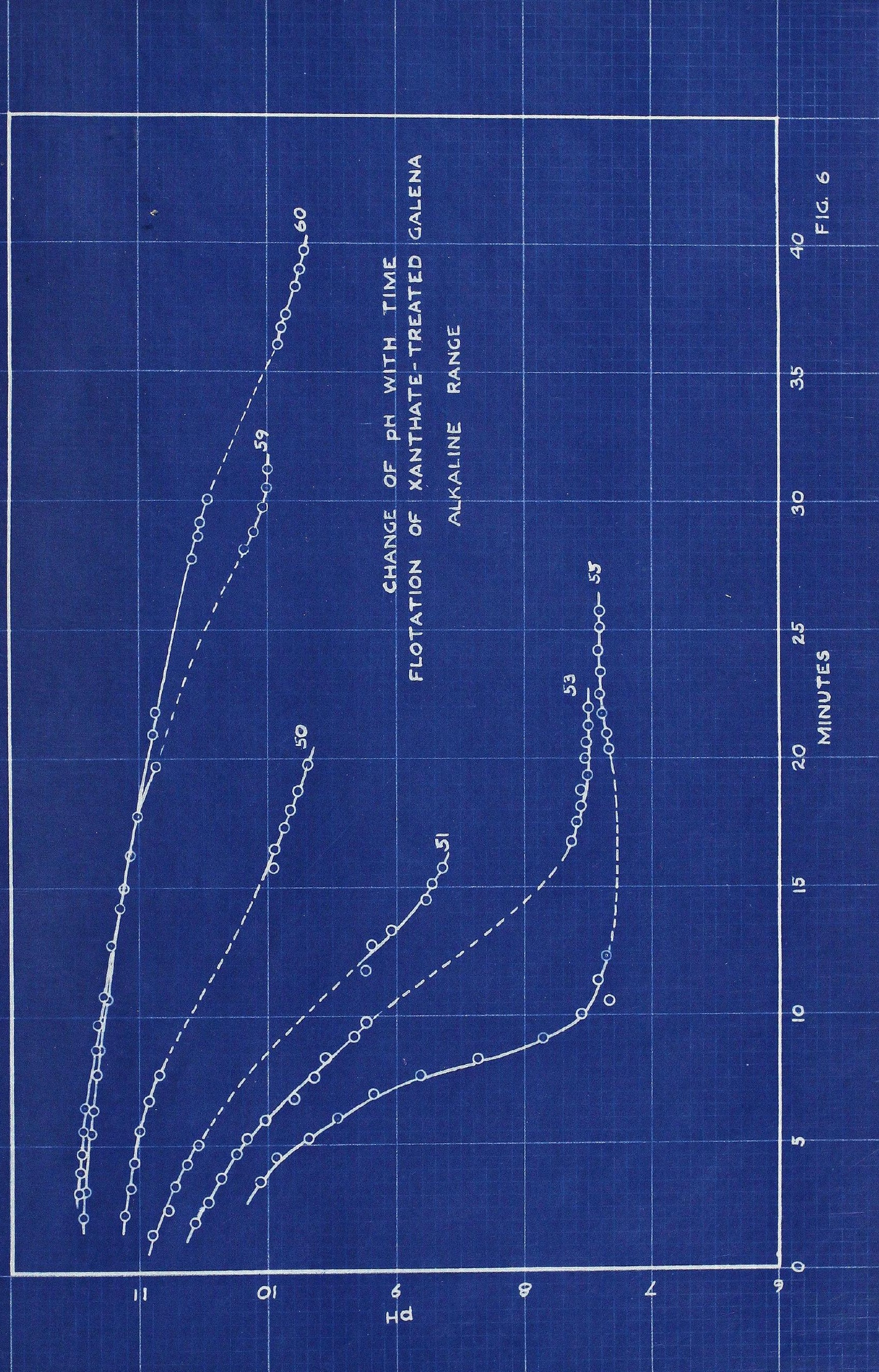




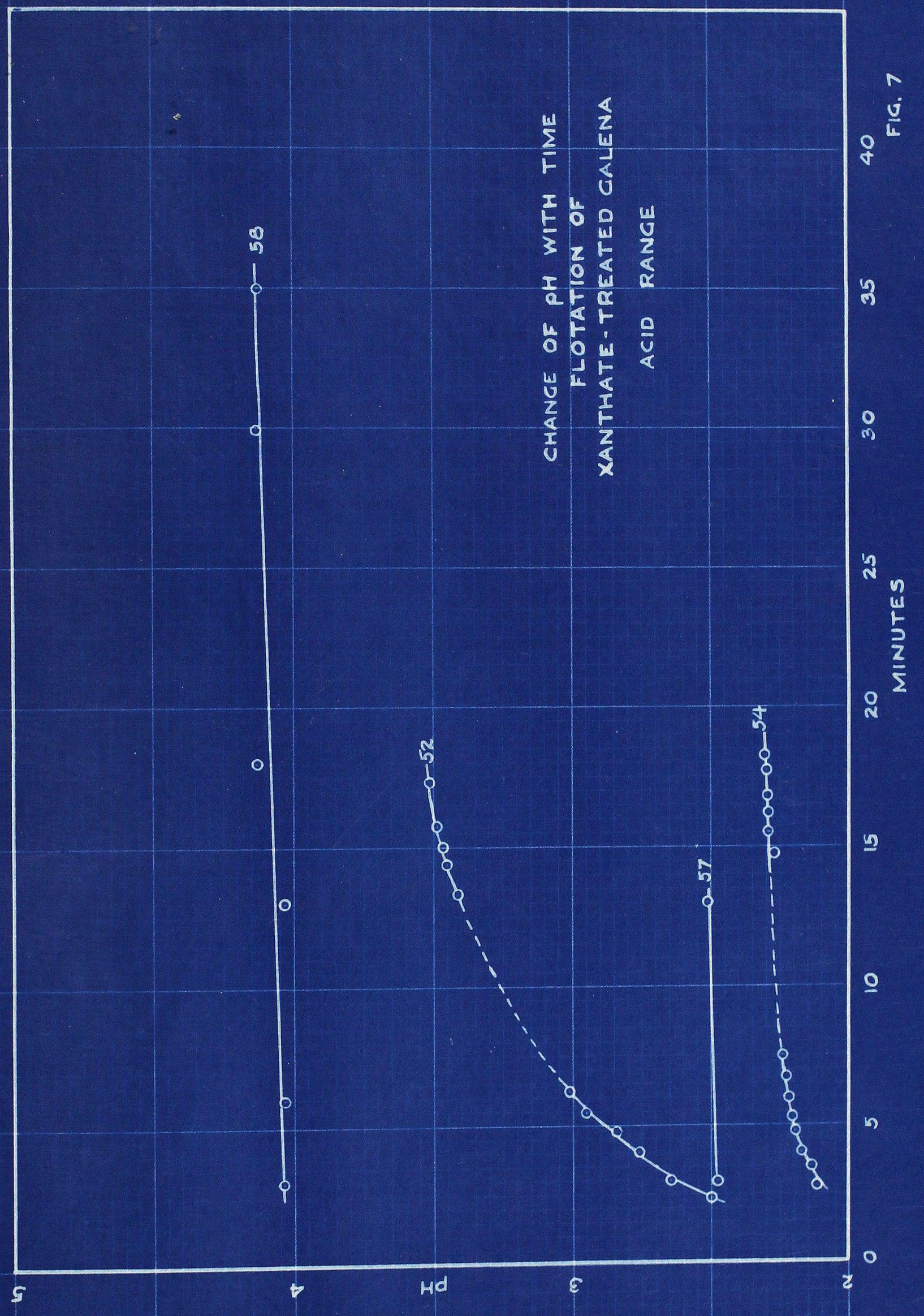


change of pil is very similar to that observed with the lead xanthat $\theta$ suspensions used in determining the solubility of lead xanthaie. The equilibrium pH of $7.4-7.5$ may correspond with the pH associated with minlmum lead xanthate solubility. It is also noteworthy that the two points on the graph (FIg. 5) for runs 59 and 60 , made with Galena $\# 5$, fall on the curve obtained for Galena \#2.

Conclusions

The graph (FIg. 5) shows that complete, or almost complete recovery of galena is attained in the $\mathrm{pH}$ range 2.5 to 9.5 (approximate). Between $\mathrm{pH} 10.0$ and 10.8 the recovery is a Inear function of the $\mathrm{pH}$, and becomes zero when the $\mathrm{pH}$ 1s 10.8 or higher. these findings substantially agree with those of Wark and Cox $(34.3 .2)$ obtained by contact angle measurements. Whese workers reported the critleal $\mathrm{pH}$ of galena in a $25 \mathrm{mgm}$. per litre potassium ethyl xanthate solution as $10.1-10.3$. 


\section{A FURTHER EFFECT OF $\mathrm{PH}$}

Procedure

- A sample of Galena \#2 was ground and sized as before, treated with potassium ethyl ranthate in the usual way, and transferred to the flotation cell with 10 ec. $0.09 \mathrm{~N}$. KOH in a pulp volume of $245 \mathrm{cc}$. Ilme was measured from the time of transfer to the cell. At $8 \mathrm{~min}, 4 \mathrm{cc}$. terpineol solution was added to make the terpineol concentration in the pulp 4 mgms. per litre; and the alp pressure was kept just below that necessary to produce overflow.

No collection of galena took place as the initial pH of 11.45 aropped to 11.2 over a period of $12 \mathrm{~min}$; but galena started to show in the froth about pH 11.15. At $16.19 \mathrm{~min}$. $10 \mathrm{cc} .0 .09 \mathrm{KOH}$ was added to bring the $\mathrm{pH}$ from 11.1 up to 11.5; but the Increase in $\mathrm{pH}$ did not appear to decroase the amount of galena in the froth.

Further aditlons of $0.09 \mathrm{~N}$ KOH were made as follows: Time $(\min ) \quad c. c . \mathrm{KOH}$ added $\mathrm{pH}$ before addition $\mathrm{pH}$ after

$\begin{array}{cccc}43 \frac{1}{2} & 5 & 10.98 & 11.28 \\ 56 \frac{1}{2} & 10 & 10.96 & 11.45 \\ 69 \frac{1}{2} & 10 & 11.17 & 11.56\end{array}$

Ihroughout this time, no decrease in the amount of galena in the froth was observed.

At 75 min. I cc. terpineol solution (250 mgm. per litre) was added: the air pressure increased to $45 \mathrm{~cm}$. of mercury, and a concentrate removed for $5 \mathrm{~min}$. 
results

The results of this run are as follows:

Head we1ght: $2.521 \mathrm{gms}$ Concentrate weight: $2.357 \mathrm{gms}$. Pulp volume: Before run $275 \mathrm{cc}$. After run $275 \mathrm{cc}$. Pulp pH: " 11.46 " $" 11.42$

\% Recovery: $\quad 93.4 \%$

Conclusions

It would appear that once galena is brought up into the froth, it is not depressed, or difficultiy depressed by a pH above the critical value.

the time factor may, however, play some part. this could be checked by controlling the addition of alkali in such a way that the pli $1 \mathrm{~s}$ always maintained above the point at which collection starts, and making the run over an extended time. 


\section{SUMMARY}

The work undertaken in the present research is exploratory in nature. The aim has been to cover a fairly wide fleld, rather than to Invostigate fully some particular phas $\theta$ of that field, in the hope that the general findings will point the way to a more exacting investigation of the problems presented. Conclusions advanced at this time should be regarded, therefore, as suggestions for further work rather than as final, carefully checked statements.

1. The concentration of load lons in equilibrium with a saturated solution of lead ethyl xanthate depends on the ph of the solution, and is a minimum at $0.15 \mathrm{mgms}$. per litro in the pH range $8.0-8.2$.

2. A pneumatic glass flotation cell has been developed and found suitablo for making measurements of floatability with samples of minerals welghing only a few grams.

3. A method for measuring the floatability of solid partleles in the absence of reagents other than water has been Investigated sufficlently to indicate that it has some merit, but requires more careful control of variables if it is required to jield quantitative results.

4. Some natural galenas may show Inherent floatability; others do not.

5. A synthetic preclpitated lead sulfide can not be floated with terpineol alone.

6. The recovery of galena treated with ethyl zanthate 
and floated in the presence of terpineol is substantially complete in solutions of $\mathrm{pH}$ less than 9.5 . The recovery is zero if the pif of the solution is 10.8 or higher.

7. A reaction of measurable rate takes place when lead xanthate, or xanthate-treated galena is placed in an aqueous acld or alkaline solution. The course of the reaction may be followed by the change in pH with time.

8. Xanthate-treated galena, once it is brought into the froth, is difficult or Impossible to depress by an increase in the pH of the pulp above the critelcal pH for the mineral.

9. some correlation may exist between the pH correspondIng to minimum solubility of lead ethyl xanthate, and the equilibrium pH attained when ranthate-treated galena is placed In an olkaline solution of pH greater than the equilibrium value. 